Concentrations of Chlorinated Hydrocarbons, Heavy Metals and Other Elements in Tissues Banked by the Alaska Marine Mammal Tissue Archival Project
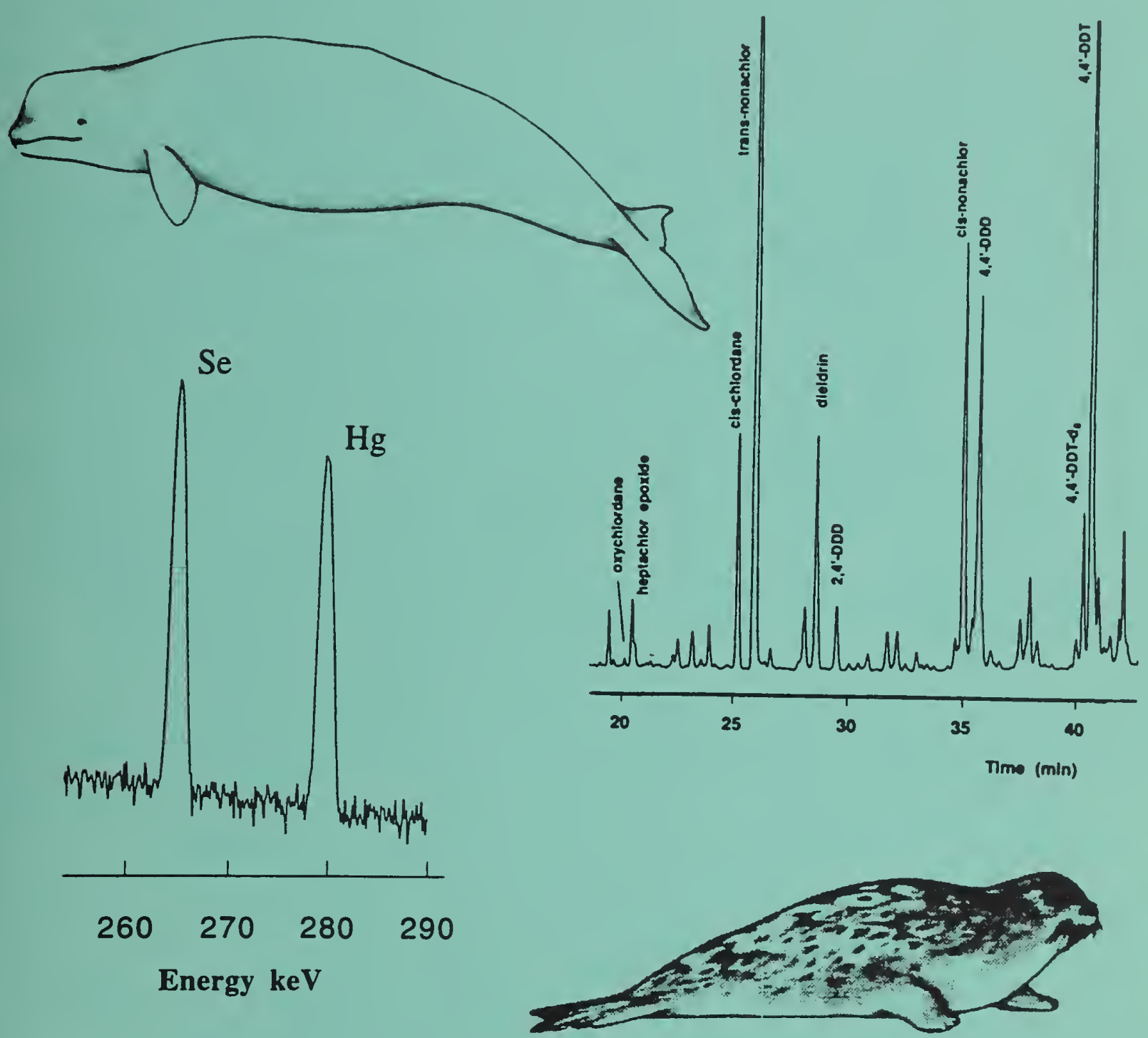

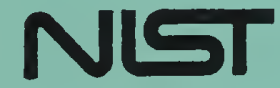

$\begin{array}{llll}260 & 270 \quad 280 \quad 290\end{array}$

Energy keV
U.S. DEPARTMENT OF COMMERCE TECHNOLOGY ADMINISTRATION NATIONAL INSTITUTE OF STANDARDS AND TECHNOLOGY

Gaithersburg, MD 20899

QC

100

.056

N0. 5620 


\title{
Concentrations of Chlorinated Hydrocarbons, Heavy Metals and Other Elements in Tissues Banked by the Alaska Marine Mammal Tissue Archival Project
}

\author{
Paul R. Becker \\ U.S. Department of Commerce \\ National Marine Fisheries Service \\ Office of Protected Resources \\ 1335 East-West Highway, SSMC-1 \\ Silver Spring, Maryland 20910-1335

\section{Elizabeth A. Mackey \\ Michele M. Schantz \\ Rabia Demiralp \\ Robert R. Greenberg \\ Barbara J. Koster \\ Stephen A. Wise}

National Oceanic and Atmospheric Administration

U.S. Department of Commerce

National Institute of Standards and Technology

Chemical Science and Technology Laboratory

Gaithersburg, Maryland 20899

\section{Derek C. G. Muir}

Department of Fisheries and Oceans Canada

Central and Arctic Region

Freshwater Institute

501 University Crescent

Winnipeg, Manitoba R3T 2N6

March 1995

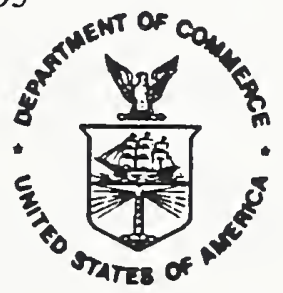

U.S. DEPARTMENT OF COMMERCE

Ronald Brown, Secretary

TECHNOLOGY ADMINISTRATION

Mary L. Good, Under Secretary for Technology

NATIONAL INSTITUTE OF STANDARDS

AND TECHNOLOGY

Arati Prabakhar, Director 


\section{PREFACE}

This is the second report in the NIST Interagency Report Series that presents analytical data on samples collected and banked as part of the Alaska Marine Mammal Tissue Archival Project (AMMTAP). The first report, Alaska Marine Mammal Tissue Archival Project: Sample Inventory and Results of Analyses of Selected Samples for Organic Compounds and Trace Elements, NISTIR-4731, 1992, contained the specimen inventory as well as analytical results. The present report represents a departure from that format in that it contains only the analytical data. A separate report, Alaska Marine Mammal Tissue Archival Project: Specimen Inventory, NISTR-5462, 1994 is devoted exclusively to the specimen inventory with all associated collection data and information.

The AMMTAP database on organic and inorganic materials in Alaska marine mammals is still relatively small. The interpretation of the data presented in this report should be considered as preliminary. 


\section{CONTENTS}

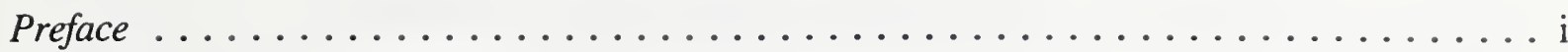

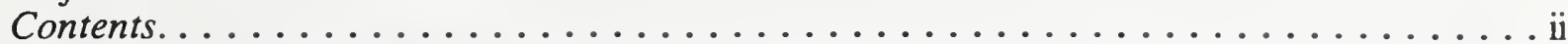

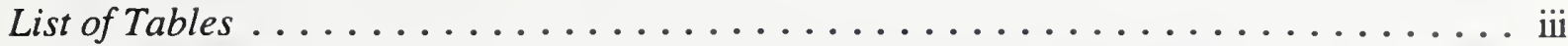

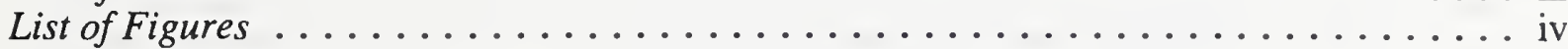

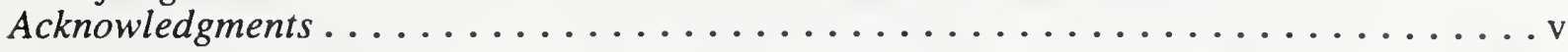

BACKGROUND $\ldots \ldots \ldots \ldots \ldots \ldots \ldots \ldots \ldots \ldots \ldots \ldots \ldots \ldots \ldots \ldots \ldots \ldots \ldots \ldots \ldots$

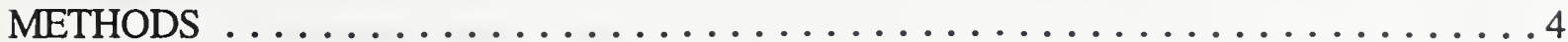

Sample Collections . . . . . . . . . . . . . . . . . . . 4

Tissue Sample Preparation . . . . . . . . . . . . . . . . . . . . 4

Chlorinated Hydrocarbon Analysis . . . . . . . . . . . . . . . . 6

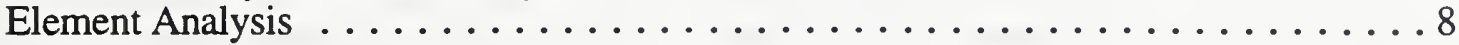

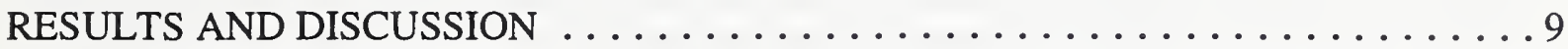

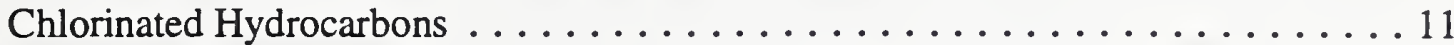

Inorganic Constituents . . . . . . . . . . . . . . . . . . 21

SUMMARY AND CONCLUSIONS $\ldots \ldots \ldots \ldots \ldots \ldots \ldots \ldots \ldots \ldots$

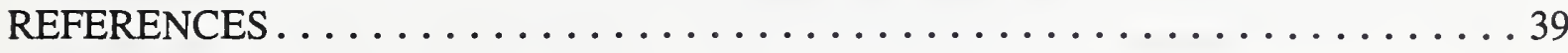

APPENDICES:

A. Chlorinated Hydrocarbon Data: Belukha Whale Blubber . . . . . . . . 45

B. Quality Control in Organic Analysis . . . . . . . . . . . . . . . . . 59

C. Inorganic Data: Liver Tissue of Pinnipeds from Norton Sound,

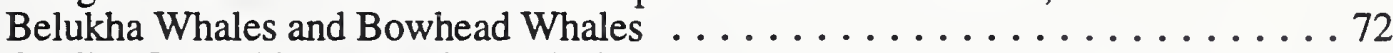

D. Quality Control in Inorganic Analysis . . . . . . . . . . . . . . . 114 


\section{TABLES}

Page

1. Locations of arrangements for routine sample collections for the AMMTAP . . . . . . 3

2. Aliquots of AMMTAP tissue samples that have been analyzed . . . . . . . . . . 5

3. Individual animal data . . . . . . . . . . . . . . . . . 10

4. Concentrations of selected chlorinated hydrocarbons in blubber of belukha whales . . . 12

5. Ratios of DDE to $\sum$ DDT in blubber of belukha whales . . . . . . . . . 16

6. Ratios of $\Sigma C H L O R$ to $\Sigma$ PCB in blubber of belukha whales . . . . . . . . 20

A1. List of abbreviations used to represent organic compounds . . . . . . . . . . 46

A2. Concentrations of PCB congeners and chlorinated pesticides in belukha whale blubber . ............................ 47

B 1. Interlaboratory comparison: concentrations of $\mathrm{PCB}$ congeners and chlorinated pesticides in SRM 1588, Organics in Cod Liver Oil . . . . . . . . . . . . 60

B2. Interlaboratory comparison: concentrations of $\mathrm{PCB}$ congeners and chlorinated pesticides in pilot whale blubber QA material . . . . . . . . . . . . . 62

B3. Interlaboratory Comparison: concentrations of PCB congeners and chlorinated pesticides in belukha whale blubber . . . . . . . . . . . . . . . 64

C1. Detection limits for inorganic constituents in marine mammal liver . . . . . . . . 74

C2. Concentrations of inorganic constituents in Bearded Seal Liver . . . . . . . . . 75

C3. Concentrations of inorganic constituents in Spotted Seal Liver . . . . . . . . . . . 80

C4. Concentrations of inorganic constituents in Ringed Seal Liver and Kidney . . . . . . . 83

C5. Concentrations of inorganic constituents in Bowhead Whale Liver . . . . . . . . . 95

C6. Concentrations of inorganic constituents in Belukha Whale Liver . . . . . . . . . 100

C7. Conversion factors for liver tissues analyzed by INAA . . . . . . . . . . . 113

D1. Quality Assurance of inorganic analyses: INAA of Control Materials . . . . . . . 115 


\section{FIGURES}

1. $\Sigma$ PCBs concentration in blubber of Arctic marine mammals . . . . . . . . . . . 14

2. $\Sigma$ DDTs concentration in blubber of Arctic marine mammals . . . . . . . . . . . 15

3. $\Sigma$ Chlordane concentration in blubber of Arctic marine mammals . . . . . . . . . 17

4. Toxaphene concentration in blubber of Arctic marine mammals . . . . . . . . . . . 18

5. Concentration of PCBs and chlorinated pesticides in blubber of belukha whales sampled by AMMTAP . . . . . . . . . . . . . . . . . . . . . . . . 19

6. Arsenic concentration in AMMTAP and NMMTB liver samples . . . . . . . . . . . . 23

7. Comparison of arsenic concentrations in marine mammal liver tissue . . . . . . . . 23

8. Cadmium concentration in AMMTAP and NMMTB liver samples . . . . . . . . . . 25

9. Comparison of cadmium concentration in liver tissue of belukha whales from Alaska and Canada . . . . . . . . . . . . . . . . . . . . 25

10. Copper concentration in AMMTAP and NMMTB liver samples . . . . . . . . . . . 27

11. Comparison of copper concentrations in liver tissue of belukha whales from Alaska and Canada . . . . . . . . . . . . . . . . . . . . . 27

12. Total mercury concentration in AMMTAP and NMMTB liver samples . . . . . . . . . 28

13. Comparison of total mercury concentration in liver tissue of belukha whales from Alaska and Canada . . . . . . . . . . . . . . . . . . . . 28

14. Selenium concentration in AMMTAP and NMMTB liver samples . . . . . . . . . . . . 30

15. Comparison of selenium concentration in liver tissue of belukha whales from Alaska and Canada . . . . . . . . . . . . . . . . . . . 30

16. Silver concentration in AMMTAP and NMMTB liver samples . . . . . . . . . . . . . 31

17. Comparison of silver concentrations in marine mammal liver tissue . . . . . . . . . . 31

18. Comparison of the of total mercury, selenium and silver concentrations in the liver tissue of animals from the AMMTAP and NMMTB . . . . . . . . . . 32

19. Vanadium concentration in AMMTAP and NMMTB liver samples . . . . . . . . . . . . 32

20. Zinc concentration in AMMTAP and NMMTB liver samples . . . . . . . . . . . . 34

21. Comparison of zinc concentrations in liver tissue of belukha whales from Alaska and Canada . . . . . . . . . . . . . . . . . . . . 34

22. Enrichment factors in belukha whale liver tissue . . . . . . . . . . . 36 


\section{ACKNOWLEDGMENTS}

The following individuals provided their time, effort, and expertise in the field collections and processing of tissue specimens included in this report:

Bowhead whales: Dr. L. Michael Philo, DVM, North Slope Borough Department of Wildlife Management (NSB/DWM), Barrow, Alaska; Dr. Kathy Burek, DVM, University of California-Davis; Dr. Peggy Barnes, DVM, Seattle, Washington; Dr. Dan Mulcahy, DVM, Anchorage, Alaska

Belukha whales: Robert Suydam, NSB/DWM, Barrow, Alaska; Geoff Carroll, Alaska Department of Fish and Game (ADF\&G), Barrow Alaska; Rex Tuzroyluk, Point Hope, Alaska; Ron Morris, National Marine Fisheries Service (NMFS), Anchorage, Alaska; Matthew Eagleton, NMFS, Anchorage, Alaska; Brad Smith, NMFS, Anchorage, Alaska; Laurie E. Jarvela, Minerals Management Service (MMS), Anchorage, Alaska; Steve Treacy, MMS, Anchorage, Alaska; Dr. Cleveland Cowles, MMS, Anchorage, Alaska.

Pinnipeds: Matthew Iya (deceased) and Roy Ashenfelter, Kawerak, Inc.; Aaron (Luke) Jackson and Timothy Gologergen, Sr., Nome, Alaska; and from the Natural Resources Department, Kawerak, Inc. - Charlie Johnson, Director, Albert Johnson, Jake Olanna, and Art Nelson.

In addition to the above, the AMMTAP would like to express its appreciation to the following people for providing advice and support: Benjamin Nageak, former Director, Warren Matumeak, Director, Charlie Brower, Subsistence Research Specialist, Harry Brower, and Dr. Thomas Albert, Senior Scientist, NSB/DWM; Dr. Henry Huntington, Special Projects Coordinator, Alaska Eskimo Whaling Commission; Ron Morris, Supervisor, Western Alaska Field Office, NMFS; Jerry Imm, Director, Division of Environmental Quality, Alaska Department of Environmental Conservation, Juneau, Alaska. We would also like to thank Dr. R. Wagemann (DFO, Canada) for his careful review of the inorganic data and the corresponding discussion. Special acknowledgments are extended to Robert Suydam, NSB/DWM, who provided the relative age data on the belukha whales and to Mark Segstro, Department of Fisheries and Oceans (DFO), Winnipeg, who performed the analytical work provided by DFO. We also gratefully acknowledge Dr. Peter Ostapczuk from Nuclear Research Center, Jülich, Germany, who provided additional trace element data and Dr. Karlheinz Ballschmiter from the Department of Analytical and Environmental Chemistry, University of Ulm, Ulm, Germany, who provided organic analyses for quality assurance.

This study was funded by the MMS, U.S. Department of the Interior, through an Inter-Agency Agreement with the National Oceanic and Atmospheric Administration, as part of the MMS Environmental Studies Program.

\section{DISCLAIMER}

Certain commercial equipment or instruments are identified in this paper to specify adequately the experimental procedures. Such identification does not imply recommendation or endorsement by the National Institute of Standards and Technology nor does it imply that the equipment or instruments are the best available for the purpose. 


\section{BACKGROUND}

Marine mammals are long-lived and most are considered to be top predators in the marine environment. Chemical analysis of their tissues can be particularly useful in determining whether bioaccumulation of contaminants and potential biological effects associated with human industrial activities are occurring in marine food webs. In the case of Alaska, the major industrial activities that might affect the marine environment consist of offshore petroleum and mineral extraction, marine transportation of petroleum and petroleum products, and the shore-based facilities associated with the petroleum and mining industries. Considering the large marine regions associated with Alaska, these industrial activities are relatively few and widely scattered. A more pervasive source of anthropogenic contaminants for Alaska and the Arctic may be industrial and agricultural activities occurring at lower latitudes. The general world-wide patterns of oceanic and atmospheric circulation, the semi-enclosed nature of the Arctic Ocean, and the climatically driven exchange between atmosphere, Arctic Ocean, polar ice cap, and land areas are conducive to transport of anthropogenic contaminants from the lower latitudes and their incorporation in the ecosystems of the Arctic. Important sources of anthropogenic contaminants for Arctic marine ecosystems include: atmospheric transport of semivolatile organic compounds (such as PCBs, chlordanes, and toxaphene) from industrial and agricultural areas and circumpolar runoffs, particularly from north-flowing rivers of Siberia (Barrie et al., 1992). These rivers discharge large volumes of freshwater containing suspended sediments and contaminants derived from the several large drainage basins.

In 1987, the Department of the Interior, Minerals Management Service (MMS) provided funds to NOAA's National Ocean Service (NOS), Ocean Assessments Division (OAD), Alaska Office to establish and conduct a program for the collection and long-term storage of tissues from Alaska marine mammals for future contaminants analysis. This program, the Alaska Marine Mammal Tissue Archival Project (AMMTAP), has been conducted as a collaborative effort between OAD and the National Institute of Standards and Technology (NIST). The collection and archival of such tissue samples over a period of several years will provide a resource that can be used to determine baseline contaminant levels against which future contaminant measures can be compared using improved analytical techniques to address questions that may arise in the future.

With the closure of the OAD Alaska Office in early 1992, principal management of the AMMTAP was transferred from NOS to the National Marine Fisheries Service (NMFS), Office of Protected Resources (OPR). The OPR manages the Marine Mammal Health and Stranding Response Program (MMHSRP). This program was established in 1992 by Public Law No. 102-587 to facilitate the collection and dissemination of data on the health of marine mammals and health trends in marine mammal populations in the wild, to correlate these trends with available data on physical, chemical, and biological environmental parameters, and to coordinate effective responses to unusual marine mammal mortalities. One component of the MMHSRP is the National Marine Mammal Tissue Bank (NMMTB). The NMMTB is similar to the AMMTAP, using basically the same collection and archival protocols and the same specimen bank facility (at NIST), but is directed toward the study of marine mammals of the contiguous 48 states of the USA.

The objectives of the AMMTAP are:

(1) to collect Alaska marine mammal tissues suitable for determining levels of organic and inorganic toxic substances;

(2) to transport, catalog, and curate the tissues in a condition suitable for long-term storage and eventual analysis; and

(3) to monitor the condition of the archived samples over time. 
In 1987, NOAA and NIST conducted a pilot project to test the use of standard procedures for collecting tissues for long-term cryogenic archival and contaminant analysis from Alaska marine mammals. Based on the results of this pilot project, which involved the collection of liver, kidney, muscle and blubber tissues from northern fur seals taken in subsistence hunts on St. Paul Island, a formal program was established and subsequently described in Becker et al. (1991). This initial report presents the rationale for the tissue types and marine mammal species selected for routine collections, and describes the standard collection and archival protocols that are used by the AMMTAP.

The Alaska Marine Mammal Tissue Archive is maintained by NIST in the National Biomonitoring Specimen Bank (NBSB), Gaithersburg, Maryland. The NBSB has been in operation for about 15 years, providing environmental specimen banking for numerous agencies and conducting cooperative development activities with similar facilities in Europe and Canada. Samples are stored at the NBSB above liquid nitrogen, in nitrogen vapor $\left(\right.$ at $\left.-150^{\circ} \mathrm{C}\right)$ to minimize sample degradation over time. The NBSB maintains an inventory of archived samples identified by type, date of collection, collection site, weight, identification numbers and other information provided by the collector. Additional information on archival procedures are provided in Becker et al. (1991), Becker et al. (1992), Wise and Zeisler (1984) and Wise et al. (1989). The current status of the NBSB has been recently reviewed by Wise et al. (1994).

From 1987 through 1994, the AMMTAP collected tissue samples from marine mammals of the Arctic Ocean, Bering Sea, and Gulf of Alaska, emphasizing species of subsistence value. The current inventory of AMMTAP samples maintained by the National Biomonitoring Specimen Bank, including the individual animal data recorded during field sampling, is presented in a separate report: NISTIR-5462, Alaska Marine Mammal Tissue Archival Project: Specimen Inventory (Koster et al., 1994). There are 329 duplicate samples of liver $(n=113)$, kidney $(n=$ $92)$, blubber $(n=119)$, and muscle $(n=5)$ banked from 119 individual animals collected from nine species: bowhead whale, Balaena mysticetus; belukha whale, Delphinapterus leucas; ringed seal, Phoca hispida; spotted seal, Phoca largha; harbor seal, Phoca vitulina; bearded seal, Erignathus barbatus; northern fur seal, Callorhinus ursinus; Steller sea lion, Eumatopias jubatus; and Pacific walrus, Odobenus rosmarus rosmarus. Arrangements for routine collections of samples have been made with several institutions (Table 1). In some cases these collections have been intermittent activities, occurring once or twice over the five-year period, and in other cases they have been continuous.

To evaluate the stability of the archived tissues, the NIST monitors the concentrations of selected trace elements and organic compounds in $10-15 \%$ of the tissue specimens. Aliquots of those specimens selected for monitoring are initially analyzed to establish the baseline levels. $\mathrm{Re}-$ analyses of aliquots of these tissues on a regular basis (every 5 - 10 years) will provide a measure of any change from the initial baseline concentrations. These analyses also provide some real-time measure of contaminant concentrations for monitoring purposes and provide a baseline for comparing contaminant levels using present analytical techniques with new or different methods in the future.

In addition to the analyses performed routinely at NIST, some collaborative analytical work with other research laboratories has been performed. For example, aliquots from all blubber samples collected from belukha whales were analyzed by Derek Muir, Department of Fisheries and Oceans (DFO) Winnipeg, Canada, for chlorinated hydrocarbons in order to expand the database on this species from eastern Canada through western Alaska. Aliquots of selected blubber samples were also analyzed by DFO, NIST and Karlheinz Ballschmiter of the University of Ulm, Germany, as part of an intercomparison exercise. Aliquots of liver samples have been analyzed by Peter Ostapczuk, Nuclear Research Center, Jülich, Germany, for elements not routinely measured by the INAA technique employed at NIST (e.g., lead and nickel) and for selected elements for comparison of analytical techniques (e.g., cadmium, cobalt, copper, and zinc). 
Table 1. Locations of arrangements for routine sample collections for the AMMTAP

Cooperating Institution

Region/Area

Species

Status

NMFS, Alaska Region

Juneau, AK and

Bering Sea

Northern Fur Seal

Intermittent

Marine Mammal Lab.

Seattle, WA

NMFS, Western Alaska

Field Office, Anchorage, AK

MMS, Anchorage, AK

Pribilof Islands

Gulf of Alaska

Cook Inlet

Belukha Whale

Ongoing

Marine Advisory Program

Alaska Sea Grant

Kodiak, AK

NSB, Dept. of Wildlife

Management, Barrow, AK

Gulf of Alaska

Kodiak Island

Steller Sea Lion

Harbor Seal

Planned

Planned

Arctic Ocean

North Slope Area

Bowhead Whale

Belukha Whale

Ringed Seal

Bearded Seal

Ongoing

Ongoing

Ongoing

Intermittent

Kawerak, Inc. and

Bering Sea

Ringed Seal

Norton Sound

Bearded Seal

Walrus

Ongoing

Ongoing

Nome, AK

USFWS, Marine Mammals Management Office

Arctic Sea and

Bering Sea

Anchorage, AK 
Previous AMMTAP analytical results which have been presented in project reports (Becker et al., 1989, 1992) and journal papers (Becker et al., 1990; Schantz et al., 1993; Zeisler et al., 1993), have been restricted to comparisons of a very limited number of subsamples from northern fur seals, ringed seals and belukha whales with published literature values (Table 2). Additional analyses have now been completed for the belukha whales from Point Hope, Point Lay and Cook Inlet, bowhead whales from Barrow and pinnipeds from Norton Sound. The results of these analyses are presented in this report.

\section{METHODS}

\section{Sample Collections}

Samples of blubber and liver were collected from belukha whales taken in Alaska Native subsistence hunts at two villages on the Chukchi Sea coast of Alaska. Four animals were sampled at Point Hope in May 1989, and ten at Point Lay in July 1990. Blubber samples were taken from three belukha whales from Cook Inlet during subsistence hunts in 1994; these have not yet been analyzed. In addition, one liver sample was collected from a belukha whale that stranded in Cook Inlet, Gulf of Alaska, in October 1992. Samples of blubber and liver were collected from 11 bowhead whales taken at Barrow (Chukchi/Beaufort seas) in the 1992 subsistence hunt. Only three of the bowhead whale liver samples have been analyzed at this time. Samples of liver were collected from pinnipeds in Barrow in 1988 and in Norton Sound during 1989, 1991, and 1993. These include samples from fourteen ringed seals, one spotted seal, and one bearded seal. Samples were also collected from two bearded seals from Nome in spring of 1993.

Sampling was conducted using the standard AMMTAP protocols designed to preserve sample integrity and minimize sample contamination from handling (Becker et al., 1988, 1991). The sex of each animal was recorded and measurements were made of standard length and blubber thickness. Weights of pinnipeds were recorded and axillary girth was recorded for pinnipeds and bowhead whales. Fluke widths of the cetaceans were measured. Lower jaws with teeth were collected from the pinnipeds and belukha whales in order to determine the age of each animal. The ages of the belukha whales sampled at Point Hope and Point Lay were determined by Robert Suydam (North Slope Borough Department of Wildlife Management) based on the number of growth layer groups counted in a thin longitudinal section taken from the middle of the mandibular tooth (Sergeant, 1959; Brodie, 1969). Removal, cutting, and reading of the teeth have been described by Burns and Seaman (1986). Ages of the single belukha from Cook Inlet and the pinnipeds from Norton Sound have yet to be determined.

Additional specimens that were collected and analyzed as part of the NMMTB are described in this report for comparison with samples from the AMMTAP. Samples of pilot whale liver were collected on Cape Cod, Massachusetts, from five animals that stranded in December 1990, and from four that stranded in September 1991. In addition, kilogram amounts of liver tissue were taken from two animals stranded in December 1990. These tissues were homogenized and pooled to form a fresh frozen quality assurance (QA) material for use in interlaboratory comparisons (Wise et al., 1993). A complete description and inventory of the NMMTB will be published elsewhere.

\section{Tissue Sample Preparation}

Each liver and blubber sample to be analyzed [derived from "Subsample B" of each archived specimen - refer to AMMTAP protocols as described in Becker et al. (1991)] was homogenized 
Table 2. Aliquots of AMMTAP tissue samples that have been analyzed. $\mathrm{O}=$ organic analysis; $\mathrm{T}=$ trace element analysis. Data previously reported in Becker et al. (1992), Schantz et al. (1993), or Zeisler et al. (1993) are indicated by an asterisk (*)

\begin{tabular}{|c|c|c|c|c|}
\hline Species & Animal Number & Sample & Sample Number & Results \\
\hline N. fur seal & 692-FRSL-004 & liver & MM1L013 & $* \mathrm{O} \quad * \mathrm{~T}$ \\
\hline N. fur seal & 692-FRSL-004 & kidney & MM1K014 & $* \mathrm{O} \quad * \mathrm{~T}$ \\
\hline N. fur seal & 692-FRSL-004 & muscle & MM1M015 & $* \mathrm{O} \quad * \mathrm{~T}$ \\
\hline N. fur seal & 692-FRSL-004 & blubber & MM1B016 & $* 0$ \\
\hline N. fur seal & 692-FRSL-005 & liver & MM1L017 & $* \mathrm{O} \quad * \mathrm{~T}$ \\
\hline N. fur seal & 692-FRSL-005 & kidney & MM1K018 & $* \mathrm{O} \quad * \mathrm{~T}$ \\
\hline N. fur seal & 692-FRSL-005 & muscle & MM1M019 & $* \mathrm{O} \quad * \mathrm{~T}$ \\
\hline N. fur seal & 692-FRSL-005 & blubber & MM1B020 & $* \mathrm{O}$ \\
\hline Ringed seal & 692-RGSL-004 & liver & MM2L030 & $* \mathrm{O} \quad * \mathrm{~T}$ \\
\hline Ringed seal & 692-RGSL-004 & kidney & MM2K031 & $* \mathrm{O} \quad * \mathrm{~T}$ \\
\hline Ringed seal & 692-RGSL-004 & blubber & $\mathrm{MM} 2 \mathrm{~B} 032$ & $* 0$ \\
\hline Ringed seal & 692-RGSL-008 & liver & MM2L042 & $* \mathrm{O} * \mathrm{~T}$ \\
\hline Ringed seal & 692-RGSL-008 & kidney & MM2K043 & $* \mathrm{O} \quad * \mathrm{~T}$ \\
\hline Ringed seal & 692-RGSL-008 & blubber & MM2B044 & $* 0$ \\
\hline Ringed seal & 692-RGSL-011 & liver & MM3L054 & $* \mathrm{O} \quad * \mathrm{~T}$ \\
\hline Ringed seal & 692-RGSL-011 & blubber & MM3B056 & $* \mathrm{O}$ \\
\hline Ringed seal & 692-RGSL-012 & liver & MM3L057 & $\mathrm{T}$ \\
\hline Ringed seal & 692-RGSL-013 & liver & MM3L060 & $* \mathrm{O} \quad * \mathrm{~T}$ \\
\hline Ringed seal & 692-RGSL-013 & blubber & MM3B062 & $* \mathrm{O}$ \\
\hline Ringed seal & 692-RGSL-014 & liver & MM3L063 & $\mathrm{T}$ \\
\hline Ringed seal & 692-RGSL-015 & liver & MM3L066 & $\mathrm{T}$ \\
\hline Ringed seal & 692-RGSL-016 & liver & MM5L155 & $\mathrm{T}$ \\
\hline Ringed seal & 692-RGSL-017 & liver & MM5L158 & $\mathrm{T}$ \\
\hline Ringed seal & 692-RGSL-018 & liver & MM5L161 & $\mathrm{T}$ \\
\hline Bearded seal & 692-BDSL-001 & liver & MM3L051 & $\mathrm{T}$ \\
\hline Spotted seal & 692-SPSL-001 & liver & MM5L164 & $\mathrm{T}$ \\
\hline Belukha whale & 692-BLKA-001 & liver & MM3L069 & $\mathrm{T}$ \\
\hline Belukha whale & 692-BLKA-001 & blubber & MM3B071 & $* \mathrm{O}$ \\
\hline Belukha whale & 692-BLKA-002 & liver & MM3L072 & $* \mathrm{~T}$ \\
\hline Belukha whale & 692-BLKA-002 & blubber & MM3B074 & $* \mathrm{O}$ \\
\hline Belukha whale & 692-BLKA-003 & liver & MM3L075 & $* \mathrm{~T}$ \\
\hline Belukha whale & 692-BLKA-004 & liver & MM3L077 & $* \mathrm{~T}$ \\
\hline Belukha whale & 692-BLKA-005 & liver & MM4L125 & $\mathrm{T}$ \\
\hline Belukha whale & 692-BLKA-005 & blubber & MM4B127 & $\mathrm{O}$ \\
\hline Belukha whale & 692-BLKA-006 & liver & MM4L128 & $\mathrm{T}$ \\
\hline Belukha whale & 692-BLKA-006 & blubber & MM4B 130 & $\mathrm{O}$ \\
\hline Belukha whale & 692-BLKA-007 & liver & MM4L131 & $* \mathrm{~T}$ \\
\hline Belukha whale & 692-BLKA-007 & blubber & MM4B133 & $* \mathrm{O}$ \\
\hline Belukha whale & 692-BLKA-008 & liver & MM4L134 & $\mathrm{T}$ \\
\hline Belukha whale & 692-BLKA-008 & blubber & MM4B136 & $\mathrm{O}$ \\
\hline Belukha whale & 692-BLKA-009 & liver & MM4L137 & $\mathrm{T}$ \\
\hline Belukha whale & 692-BLKA-009 & blubber & MM4B139 & $\mathrm{O}$ \\
\hline Belukha whale & 692-BLKA-010 & liver & MM4L140 & $\mathrm{T}$ \\
\hline Belukha whale & 692-BLKA-010 & blubber & MM4B142 & $\mathrm{O}$ \\
\hline
\end{tabular}


using a cryogenic procedure designed to reduce the likelihood of changes in sample composition due to thawing and re-freezing (Zeisler et al., 1983). The sample homogenate, a frozen powder, was then aliquoted into Teflon jars $(10 \mathrm{~mL}$ and $90 \mathrm{~mL})$ for analysis and for storage as the homogenate. A summary of specimens from the AMMTAP that have been homogenized for organic and inorganic analyses is provided in Table 2.

\section{Chlorinated Hydrocarbon Analysis}

Measurements for the determination of chlorinated hydrocarbons were performed in the Analytical Chemistry Division at NIST and at two other laboratories. Results from the analysis of four belukha whale blubber samples (BLKA-001 and 002 from Point Hope and BLKA-007 and 012 from Point Lay) have been reported previously (Becker et al., 1992 and Schantz et al. 1993). Two additional belukha whale blubber samples (BLKA-002 and BLKA-005) were analyzed at NIST. Subsamples of 12 belukha whale blubber specimens from the AMMTAP (BLKA-001 through 014) were provided to Derek Muir at the Department of Fisheries and Oceans, Winnipeg, Canada as part of a collaborative effort to compare contaminant data for belukha whales from both Alaska and Canada. Subsamples of four of the same belukha whale blubber specimens were also sent to Professor Karlheinz Ballschmiter at the Department of Analytical and Environmental Chemistry, University of Ulm in Ulm Germany. The analyses of subsamples of the same specimens at NIST, the University of Ulm, and the Department of Fisheries and Oceans provided a three way intercomparison exercise.

\section{Methods--NIST}

Four belukha whale blubber samples were analyzed at NIST using the methodology described in a previous report (Becker et al., 1992). Briefly, 2 - $3 \mathrm{~g}$ of the blubber homogenate were mixed with approximately $100 \mathrm{~g}$ of pre-extracted sodium sulfate. These mixtures were spiked with an internal standard solution containing perdeuterated 4,4'-DDT, PCB 103, and PCB 198 and Soxhlet extracted for $18 \mathrm{~h}$ using methylene chloride. The extracts were concentrated and about $1 \mathrm{~mL}$ was used for size exclusion chromatography (SEC). The SEC step was used to remove the majority of the lipid and biogenic material. Following the SEC step, normal-phase liquid chromatography (LC) on a semi-preparative-scale aminopropylsilane column was used to isolate two fractions containing: (1) the PCB congeners and lower polarity chlorinated pesticides and (2) the more polar chlorinated pesticides.

Extracts were analyzed by capillary gas chromatography with electron capture detection (GC-ECD) using a $60 \mathrm{~m} \times 0.25 \mathrm{~mm}$ i.d. $5 \%$ phenylmethylpolysiloxane capillary column with helium carrier gas. PCB congeners and pesticides were quantified using a series of mixtures obtained from NIST. NIST SRM 1588 (Organics in Cod Liver Oil) was analyzed with each set of blubber samples as a control material.

The quality and comparability of the analytical data generated for the AMMTAP is assured by participation in the quality assurance component of the NMFS's Marine Mammal Health and Stranding Response Program. This Quality Assurance Program is described in Wise (1993) and Wise et al. (1993).

\section{Methods--Department of Fisheries and Oceans}

Analyses of blubber specimens were performed at the Department of Fisheries and Oceans (DFO) using methods described in Muir et al. (1988a, 1988b, 1990) and Stern et al. (1994). In summary, samples of blubber $(2-5 \mathrm{~g}$ ) were mixed with anhydrous sodium sulfate (heated $6 \mathrm{~h}$ at $600^{\circ} \mathrm{C}$ prior to use) and extracted by ball-milling (30 min) with hexane. The extract was allowed 
to stand for $4 \mathrm{~h}$ before being centrifuged. Internal standards of aldrin and octachloro-naphthalene $(\mathrm{OCN})$ were added at the extraction step. Extractable lipid was determined gravimetrically using $1 / 10$ of the extract. Following evaporation of the solvent, a portion of the sample extract equivalent to $1 \mathrm{~g}$ of lipid was chromatographed on an automated gel permeation column to separate chlorinated hydrocarbons from co-extracted lipids, and then fractionated on Florisil into three eluates: hexane (F1); hexane:dichloromethane (85:15) (F2); hexane:dichloro-methane (1:1) (F3) (Norstrom and Won 1985). The chromatography on Florisil separates PCB congeners, chlorobenzenes, 4,4'-DDE, and mirex in F1 from most toxaphene, chlordane-related compounds, and 4,4'-DDT in F2. F3 contains heptachlor epoxide and dieldrin.

Extracts were analyzed by capillary gas chromatography with electron capture detection (GC-ECD) using a $60 \mathrm{~m}$ x $0.25 \mathrm{~mm}$ i.d. $5 \%$ phenylmethylpolysiloxane capillary column with hydrogen carrier gas. A volume correction standard (PCB 30) was added to samples prior to GC analysis. PCB congeners were quantified using a series of congener mixtures obtained from NIST or purchased from Ultra Scientific (North Kingston, RI). Where congeners were not available, response factors (RFs) were estimated from other congeners with the same number of chlorines. NIST SRM 1588 (Organics in Cod Liver Oil) was analyzed every 20 samples as a control sample.

Chlordane-related compounds were quantified with individual standards excluding nonachlor III for which the RF for trans-nonachlor was used. Minor chlordane components, "C", C1, C2, and C4 were quantified using the RF for heptachlor while C5 was quantified using the RF of transnonachlor. (See Dearth and Hites, 1992, for a discussion of chlordane components.) Total chlordane was the sum of all chlordane-related compounds including heptachlor epoxide.

Toxaphene was quantified by a modification of previous procedures described by Muir et al. (1988b) and Stern et al. (1994). RFs for individual toxaphene peaks were calculated from the weight percent of each peak in the total ion chromatogram of a toxaphene standard as determined by electron-impact mass spectrometry on a GC-mass selective detector. Total toxaphene was the sum of the concentrations of 19 peaks (14 major peaks were generally observed).

\section{Methods--University of Ulm}

Four belukha whale blubber samples were analyzed at the University of Ulm. Samples of blubber $(0.4-5 \mathrm{~g})$ were mixed with sodium sulfate and coarse sand and extracted by a column technique using hexane/acetone (7/4) [Ernst et al., 1974]. Prior to extraction, tetrachloronaphthalene and $\varepsilon$ $\mathrm{HCH}$ were added as internal standards. The extractable lipid content was determined gravimetrically. To remove the majority of the lipids from the extracts, two different clean-up steps were used: gel permeation and concentrated sulfuric acid. After removal of the lipids, the eluants were concentrated to $500 \mu \mathrm{L}$. Liquid chromatography on a self-made column was used to separate the organic residues into three fractions. The first fraction contains the PCB congeners and lower polarity pesticides, such as HCB, 4,4'-DDE, and mirex. The second fraction contains the more polar pesticides, such as the HCHs, DDDs, DDTs, chlordane compounds, and toxaphene. The third fraction contains dieldrin which is destroyed in the sulfuric acid clean-up. The three fractions were each concentrated to $200-600 \mu \mathrm{L}$, then spiked with internal standard solutions, PCB 103 for the first fraction and tetrachloronaphthalene for the second and third fractions.

Extracts were analyzed by GC-ECD using a $100 \mathrm{~m}$ x $0.32 \mathrm{~mm}$ i.d. $50 \%$ octylmethylpolysiloxane capillary column with hydrogen as carrier gas. PCB congeners and pesticides were quantified using a series of solutions obtained from NIST. NIST SRM 1588 was analyzed with each set of blubber samples as a control material. 


\section{Element Analysis}

Major and trace element analyses were performed on aliquots of liver samples collected from ringed seals taken in Norton Sound in 1989, 1991, and 1993 (RGSL-011 - 018, RGSL-029 032); one bearded seal from Norton Sound in 1989 (BDSL-001); two bearded seals taken in Nome in 1993 (BDSL-004 - 005); one spotted seal taken in Norton Sound in 1991 (SPSL-001); three bowhead whales taken at Barrow in 1992 (BWHD-001, -006, -007); and belukha whales taken at Point Hope in 1989 (BLKA-001 - 004), Point Lay in 1990 (BLKA-005 - 014), and Cook Inlet in 1992 (BLKA-015). These analyses were performed in the Analytical Chemistry Division at NIST.

The analytical approach for the determination of elements focuses on the use of a multi-element analytical technique, instrumental neutron activation analysis (INAA), to provide data on a large number of trace elements using only a limited amount of sample. This method consists of exposing samples and standards to a neutron field to produce radioactivity and measuring the energy and amount of the resulting radiation. In the neutron field, many of the stable nuclides of elements comprising the sample undergo neutron capture which, for many elements, results in the formation of radioactive product nuclides. The gamma ray emissions from the resulting product nuclides are collected using a germanium detector. The energy of the gamma ray indicates from which element the product nuclide was formed and the amount of radiation emitted is proportional to the concentration of that element.

In preparation for INAA, the frozen homogenate from each sample was lyophilized and two 200mg portions of the resulting powder were formed into disk-shaped pellets, each packaged in acidwashed linear polyethylene (LPE) film. Duplicate portions of standard reference materials (SRMs) were prepared in the same manner and included in the analysis scheme for quality control purposes. Standards consisted of known amounts of each element deposited onto filter papers. These filter papers were also formed into disks so that counting geometry was consistent between samples, controls, and standards.

The irradiation and counting times for INAA were chosen to optimize the number of elements that could be determined and the detection limits for each. The samples, standards and controls were subjected to two irradiations, the first for $120 \mathrm{~s}$ and the second for $16 \mathrm{~h}$. Approximately $90 \mathrm{~s}$ after the first irradiation, the samples were counted for $5 \mathrm{~min}$ to determine elements for which the product nuclides possess very short half-lives (magnesium, aluminum, chlorine, calcium, vanadium, copper, iodine, bromine). After several hours of decay, samples are counted again for $20 \mathrm{~min}$ to determine nuclides that possess half-lives on the order of a few hours (sodium, potassium, manganese). Each sample and control material was then repackaged in clean LPE film in preparation for the second irradiation. After the second irradiation and a decay time of approximately 6 days, each sample was counted for $4 \mathrm{~h}$ to determine concentrations of molybdenum, arsenic, cadmium, antimony, lanthanum, samarium, gold, and uranium; after a decay time of $1-2$ months, samples were counted for $8 \mathrm{~h}$ to determine scandium, iron, zinc, cobalt, selenium, rubidium, strontium, molybdenum, silver, antimony, cesium, barium, cerium, europium, terbium, hafnium, tantalum, and thorium concentrations. All irradiations were done at the NIST Reactor, at a reactor power of $15 \mathrm{MW}$ which corresponds to a neutron fluence rate of approximately $2.0 \times 10^{13} \mathrm{~cm}^{-2} \cdot \mathrm{s}^{-1}$. Quantitation was based on comparison with standards. The ratio of the amount of activity induced in the standard at the end of the irradiation per unit mass of element $\left(\mathrm{A}_{\mathrm{o}} / \mathrm{g}\right)$ is calculated and this value or standard constant is used to determine the amount of element present in the sample based on the amount of activity measured in the sample. Spectral and data reduction for all samples were performed using a $\mu$ VAX 3400 computer with Nuclear Data software.

For mercury analyses, additional portions of lyophilized liver tissue were packaged in acid-washed quartz vials. Mercury analysis could not be performed on the subsamples that were packaged in 
LPE film because during irradiation, the samples are heated and volatile elemental mercury and mercury compounds may permeate the film. These samples in quartz vials were irradiated for $5 \mathrm{~h}$ and allowed to decay for about two months after which gamma spectroscopy was performed.

For the determination of all trace elements except mercury, SRM 1577a Bovine Liver was analyzed and, for the determination of mercury, SRM 1572 Citrus Leaves and SRM 2710 Montana Soil I were analyzed. The results of these analyses are shown together with the certified values in Appendix D, Table D-1. Results of INAA generally agree with certified values within the analytical uncertainty of the method. The uncertainty of the method includes the uncertainties associated with counting statistics, uncertainty in the concentrations of the standards, differences between standards and uncertainties due to differences in counting geometry. The magnitude of the uncertainty associated with counting statistics varies greatly from element to element and from animal to animal depending on the levels present. The magnitude of uncertainty in the concentration of the standards is estimated to be $<1 \%$ at the $1 \mathrm{~s}$ level. The uncertainty associated with differences in counting geometry between samples and standards is estimated based on experience to be approximately $1 \%$ for the disk-shaped samples and approximately $2 \%$ for the powdered samples contained in quartz vials. For many elements, the uncertainty associated with counting statistics is the largest source of uncertainty.

Analyses of liver samples for six of the fourteen belukha whales and two of the Norton Sound ringed seals were performed during 1990 -1991; these results have been published elsewhere (Becker et al., 1992 and Zeisler et al., 1993) but are included here for completeness. Similar INAA procedures were used for the analysis of these samples for the determination of all elements except nickel, lead, and mercury which were determined using other techniques as described below.

Additional analytical techniques were used to provide data on elements of high priority that are not routinely measured by INAA (e.g., lead and nickel) and to provide quality control data for selected elements (copper, zinc, and mercury) by comparing data from two different analytical techniques. Nickel and lead were determined using differential pulse and square wave voltammetry using previously published procedures for biological and environmental samples (Ostapczuk et al., 1986) after high pressure ashing digestion with nitric acid (Würfels et al., 1989). Mercury concentrations were determined using cold vapor atomic absorption spectrometry (CVAAS). Methodological details are presented in May and Stoeppler (1984), and Zeisler et al. (1993).

\section{RESULTS AND DISCUSSION}

Information including relative age, sex, date and location sampled, and morphometric measurements made on the individual animals is presented in Table 3. Complete information on each sample in the AMMTAP inventory is provided in Koster et al. (1994). Age estimates are not yet available for the pinnipeds and the single belukha whale from Cook Inlet. For the belukha whales, the numbers reported as "age indicator" are not absolute ages, but are the number of growth layer groups in longitudinal tooth sections. Belukha whales most likely lay down two growth layer groups per year (Brodie, 1982; Goren et al., 1987). 
Table 3. Individual animal data. The numbers reported as "age indicator" for the belukha whales are not absolute ages but are the number of growth layer groups in longitudinal tooth sections.

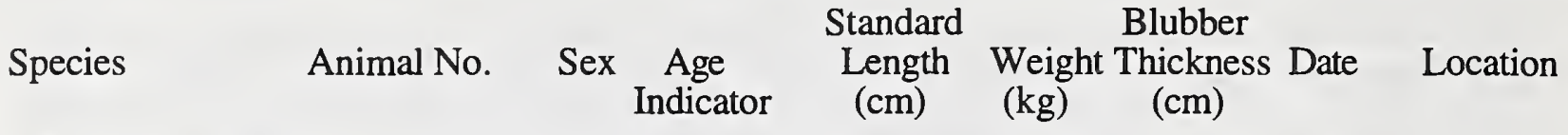

\begin{tabular}{|c|c|c|c|c|c|c|c|c|}
\hline Ringed seal & RGSL-011 & M & --- & 119.5 & 33.6 & 4.0 & $5 / 89$ & Norton S. \\
\hline Ringed seal & RGSL-012 & $\mathrm{F}$ & --- & 124.5 & 36.3 & 3.5 & $5 / 89$ & Norton S. \\
\hline Ringed seal & RGSL-013 & M & --- & 103.5 & 31.8 & 4.5 & $5 / 89$ & Norton S. \\
\hline Ringed seal & RGSL-014 & M & --- & 101.0 & 29.5 & 3.0 & $5 / 89$ & Norton S. \\
\hline Ringed seal & RGSL-015 & $\mathrm{F}$ & immature & 83.2 & 20.0 & 3.3 & $5 / 89$ & Norton S. \\
\hline Ringed seal & RGSL-016 & M & immature & 81.5 & 13.6 & 4.0 & $5 / 91$ & Norton S. \\
\hline Ringed seal & RGSL-017 & $\mathrm{F}$ & --- & 113 & 40.8 & 7.0 & $5 / 91$ & Norton S. \\
\hline Ringed seal & RGSL-018 & $\mathrm{F}$ & --- & 87 & 21.8 & 2.0 & $5 / 91$ & Norton S. \\
\hline Bearded seal & BDSL-001 & $\mathbf{M}$ & --- & 166.7 & -- & 4.5 & $5 / 89$ & Norton S. \\
\hline Spotted seal & SPSL-001 & $\mathrm{F}$ & -- & 157.5 & --- & 8.5 & $5 / 91$ & Norton S. \\
\hline Belukha whale & BLKA-001 & $\mathrm{F}$ & 16 & 343 & -- & --- & $5 / 89$ & Pt. Hope \\
\hline Belukha whale & BLKA-002 & $\mathrm{F}$ & 9 & 310 & --- & 7.6 & $5 / 89$ & Pt. Hope \\
\hline Belukha whale & BLKA-003 & $\mathrm{F}$ & 20 & 348 & --- & -- & $5 / 89$ & Pt. Hope \\
\hline Belukha whale & BLKA-004 & M & 11 & 348 & --- & 7.0 & $5 / 89$ & Pt. Hope \\
\hline Belukha whale & BLKA-005 & M & 30 & 394 & --- & 3.7 & $7 / 90$ & Pt. Lay \\
\hline Belukha whale & BLKA-006 & $\mathbf{M}$ & --- & 430 & $-\cdots$ & 6.5 & $7 / 90$ & Pt. Lay \\
\hline Belukha whale & BLKA-007 & $\mathrm{F}$ & 43 & 363 & -- & 7.7 & $7 / 90$ & Pt. Lay \\
\hline Belukha whale & BLKA-008 & $\mathrm{M}$ & 13 & 364 & --- & --- & $7 / 90$ & Pt. Lay \\
\hline Belukha whale & BLKA-009 & M & 13 & 348 & --- & 3.7 & $7 / 90$ & Pt. Lay \\
\hline Belukha whale & BLKA-010 & M & 23 & 400 & -- & --- & $7 / 90$ & Pt. Lay \\
\hline Belukha whale & BLKA-011 & M & 28 & 433 & --- & --- & $7 / 90$ & Pt. Lay \\
\hline Belukha whale & BLKA-012 & $\mathrm{F}$ & 55 & 375 & --- & --- & $7 / 90$ & Pt. Lay \\
\hline Belukha whale & BLKA-013 & $\mathrm{M}$ & 26 & 434 & --- & 8.4 & $7 / 90$ & Pt. Lay \\
\hline Belukha whale & BLKA-014 & $\mathrm{F}$ & 23 & 351 & --- & -- & $7 / 90$ & Pt. Lay \\
\hline Belukha whale & BLKA-015 & M & -- & 373 & --- & 15.5 & $10 / 92$ & Cook Ínlet \\
\hline Bowhead & BWHD-001 & $\mathrm{F}$ & immature & 853 & -- & --- & $5 / 92$ & Barrow \\
\hline Bowhead & BWHD-006 & $\mathrm{F}$ & --- & 1495 & --- & 25 & $9 / 92$ & Barrow \\
\hline Bowhead & BWHD-007 & $\mathbf{M}$ & --- & 1450 & --- & 20.5 & $9 / 92$ & Barrow \\
\hline
\end{tabular}




\section{Chlorinated Hydrocarbons}

Analytical data for chlorinated hydrocarbons in twelve belukha whale blubber samples are presented in Appendix A, Table A-1. These analyses were performed at the DFO for the determination of 120 chlorinated hydrocarbon compounds: 85 PCB congeners and 35 pesticide compounds including four chlorobenzenes, three $\mathrm{HCH}$ isomers, 15 chlordane compounds, six DDT compounds, mirex, dieldrin, and toxaphene. For most samples PCB 128 was below the detection limit; however, this may have been due to incomplete separation from nonachlorobornane (T12), a toxaphene compound, on Florisil. The co-elution of an octachlorobornane (T2) with PCB $144 / 135$ was also possible.

For comparison with previously published data generated by the use of electron-capture negative ion mass spectrometry, the TOXSRF values presented in Table A-1 are used to represent the sum of toxaphene. The TOXSRF values were calculated using a single response factor based on the area of 20 peaks in the standard, and the same peaks in the sample as described by Muir et al. (1990).

The sum of PCBs, toxaphene, DDTs, and chlordanes contributed the largest fractions to the total chlorinated hydrocarbon concentrations. The relatively large contribution of chlordane and toxaphene is similar to that reported for other Arctic marine mammals and appears to be characteristic of North American Arctic marine ecosystems (Muir et al., 1992a). The values for the major components are quite similar to the values reported for belukha whales from the Canadian Arctic (Muir et al., 1990) and western Greenland (Stern et al., 1994), particularly for belukha whales sampled from the Mackenzie River region, and major congeners contributing to the total PCB values are basically the same.

The following were the ranges of the major chlorinated hydrocarbon components (in $\mu \mathrm{g} / \mathrm{g}$ wet weight) for all belukha whale blubber samples from the AMMTAP: $\Sigma$ PCBs $=0.6-5.0$; $\Sigma$ TOXSRF $=0.5-5.4 ; \Sigma$ DDTs $=0.3-3.8 ; \Sigma$ chlordane $=0.3-2.4 ; \mathrm{HCB}=0.08-0.95 ;$ and $\Sigma \mathrm{HCH}=0.08-0.48$. Oxychlordane and trans-nonachlor contributed the most to the total chlordane concentration. $\beta-\mathrm{HCH}$ and $\alpha-\mathrm{HCH}$ contributed the most to the total $\mathrm{HCH}$, while the $\gamma-$ $\mathrm{HCH}$ isomer (lindane), contributed only a relatively small proportion. Major PCB congeners were $153,138,149,118,101,99,180,187,52$, and $66 / 95$.

In Table 4, concentration values for $\Sigma$ PCBs ( 85 congeners), $\Sigma$ toxaphene (TOXSRF), $\Sigma$ DDTs (six compounds), $\Sigma$ chlordanes (15 compounds), $\Sigma$ chlorobenzenes, HCB, $\Sigma \mathrm{HCH}$, trans-nonachlor, dieldrin, and mirex in (AMMTAP) belukha whale blubber tissues collected from animals in the Chukchi and western Beaufort seas are compared to values reported by Muir et al. (1990) for belukha whales from the Mackenzie Bay, which lies in the eastern Beaufort Sea. The values for the animals from the three locations are very similar. Males consistently had higher levels of PCBs, toxaphene, DDTs, and chlordanes than the females. Based on the present understanding of populations of belukha whales inhabiting the Chukchi, Beaufort, and Bering Seas, the Mackenzie Bay animals are probably from the same population as those sampled by AMMTAP at Point Hope. However, the degree of genetic and geographic separation of the Point Lay animals from the Point Hope/Mackenzie Bay group is presently unknown. The belukha whales that were sampled at Point Hope summer in the eastern Beaufort Sea, while those from Point Lay summer in the Chukchi Sea. It is not known if they winter together, although all of the belukha whales in the Alaska Arctic apparently winter in various ice-free areas of the Bering and possibly Chukchi seas (Hazard, 1988). Even if the AMMTAP belukha whales represent two different groups or populations, the source of exposure to chlorinated hydrocarbons (atmospheric input) may be the same, since it appears from these data that there is no difference in the chlorinated hydrocarbon levels in the animals from Point Lay as compared to those from Point Hope/Mackenzie Bay. 
Table 4. Concentration ( $\mu \mathrm{g} / \mathrm{g}$ wet weight) of selected chlorinated hydrocarbons measured in blubber of belukha whales from the Chukchi/Beaufort seas. Values are mean \pm 1 standard deviation, with the range shown below the mean. Standard deviation is not given for $n=2$. Mackenzie Bay values are from Muir et al. (1990).

\begin{tabular}{|c|c|c|c|c|c|}
\hline & \multirow{2}{*}{$\begin{array}{c}\text { POINT HOPE } \\
1989 \\
\text { females } \\
n=2\end{array}$} & \multicolumn{2}{|c|}{$\begin{array}{c}\text { POINT LAY } \\
1990\end{array}$} & \multicolumn{2}{|c|}{$\begin{array}{c}\text { MACKENZIE BAY } \\
1983,1987\end{array}$} \\
\hline & & $\begin{array}{l}\text { females } \\
n=3\end{array}$ & $\begin{array}{l}\text { males } \\
\mathrm{n}=7\end{array}$ & $\begin{array}{l}\text { females } \\
\mathrm{n}=2\end{array}$ & $\begin{array}{l}\text { males } \\
\mathrm{n}=10\end{array}$ \\
\hline$\Sigma \mathrm{PCB}$ & $\begin{array}{c}2.37 \\
2.08-2.66\end{array}$ & $\begin{array}{l}2.64 \pm 1.73 \\
0.65-4.41\end{array}$ & $\begin{array}{l}4.59 \pm 0.64 \\
3.56-5.23\end{array}$ & $\begin{array}{c}1.23 \\
0.83-1.64\end{array}$ & $\begin{array}{l}3.33 \pm 0.85 \\
2.32-4.94\end{array}$ \\
\hline$\Sigma$ TOXSRF & $\begin{array}{c}3.06 \\
2.64-3.48\end{array}$ & $\begin{array}{l}2.62 \pm 2.07 \\
0.50-4.64\end{array}$ & $\begin{array}{l}3.93 \pm 1.16 \\
2.16-5.38\end{array}$ & $\begin{array}{c}1.38 \\
1.12-1.63\end{array}$ & $\begin{array}{l}3.83 \pm 1.16 \\
2.55-6.62\end{array}$ \\
\hline$\Sigma D D T$ & $\begin{array}{c}1.24 \\
1.14-1.33\end{array}$ & $\begin{array}{l}1.92 \pm 1.42 \\
0.33-3.31\end{array}$ & $\begin{array}{l}3.25 \pm 0.69 \\
2.09-3.82\end{array}$ & $\begin{array}{c}0.67 \\
0.46-0.88\end{array}$ & $\begin{array}{l}2.20 \pm 0.83 \\
1.47-3.73\end{array}$ \\
\hline$\Sigma$ CHLOR & $\begin{array}{c}1.32 \\
1.09-1.55\end{array}$ & $\begin{array}{l}1.38 \pm 0.87 \\
0.33-2.17\end{array}$ & $\begin{array}{l}2.22 \pm 0.21 \\
1.95-2.42\end{array}$ & $\begin{array}{c}0.67 \\
0.44-0.89\end{array}$ & $\begin{array}{l}1.75 \pm 0.41 \\
1.28-2.56\end{array}$ \\
\hline$\Sigma \mathrm{CBZ}$ & $\begin{array}{c}0.62 \\
0.25-0.99\end{array}$ & $\begin{array}{l}0.58 \pm 0.39 \\
0.09-0.92\end{array}$ & $\begin{array}{l}0.87 \pm 0.10 \\
0.78-1.04\end{array}$ & $\begin{array}{c}0.33 \\
0.19-0.47\end{array}$ & $\begin{array}{l}0.65 \pm 0.15 \\
0.43-0.85\end{array}$ \\
\hline HCB & $\begin{array}{c}0.78 \\
0.67-0.90\end{array}$ & $\begin{array}{l}0.56 \pm 0.38 \\
0.08-0.89\end{array}$ & $\begin{array}{l}0.81 \pm 0.09 \\
0.74-0.95\end{array}$ & $\begin{array}{l}0.29 \\
0.16-0.41\end{array}$ & $\begin{array}{l}0.59 \pm 0.13 \\
0.40-0.78\end{array}$ \\
\hline$\Sigma \mathrm{HCH}$ & $\begin{array}{c}0.38 \\
0.29-0.46\end{array}$ & $\begin{array}{l}0.25 \pm 0.12 \\
0.08-0.36\end{array}$ & $\begin{array}{l}0.32 \pm 0.08 \\
0.26-0.48\end{array}$ & $\begin{array}{c}0.17 \\
0.17-0.17\end{array}$ & $\begin{array}{l}0.23 \pm 0.06 \\
0.14-0.32\end{array}$ \\
\hline t-nonachlor & $\begin{array}{c}0.58 \\
0.50-0.66\end{array}$ & $\begin{array}{l}0.67 \pm 0.43 \\
0.18-1.08\end{array}$ & $\begin{array}{l}1.06-0.12 \\
0.88-1.27\end{array}$ & $\begin{array}{l}0.21 \\
0.11-0.31\end{array}$ & $\begin{array}{l}0.53 \pm 0.12 \\
0.32-0.72\end{array}$ \\
\hline Dieldrin & $\begin{array}{c}0.21 \\
0.14-0.28\end{array}$ & $\begin{array}{l}0.24 \pm 0.16 \\
0.05-0.41\end{array}$ & $\begin{array}{l}0.34 \pm 0.06 \\
0.28-0.42\end{array}$ & $\begin{array}{c}0.10 \\
0.07-0.14\end{array}$ & $\begin{array}{l}0.23 \pm 0.05 \\
0.16-0.34\end{array}$ \\
\hline Mirex & $\begin{array}{c}0.02 \\
0.01-0.02\end{array}$ & $\begin{array}{l}0.04 \pm 0.02 \\
0.02-0.07\end{array}$ & $\begin{array}{l}0.05 \pm 0.02 \\
0.03-0.07\end{array}$ & $\begin{array}{l}0.02 \\
0.01-0.03\end{array}$ & $\begin{array}{l}0.04 \pm 0.01 \\
0.02-0.06\end{array}$ \\
\hline
\end{tabular}


In Figures 1 and 2, $\Sigma$ PCB and $\Sigma$ DDT concentrations in belukha whale blubber are compared to values that have been published since 1980 for other Arctic marine mammal species. The values for the Alaska belukha whales were similar to those reported for belukha whales from the Canadian Arctic and western Greenland ( $\leq 5 \mu \mathrm{g} / \mathrm{g}$ wet weight), narwhals and polar bears, but an order of magnitude less than those reported for belukha whales from the St. Lawrence River estuary.

DDE is a metabolite of the parent compound, DDT. Since DDE is relatively stable and tends to persist, it accumulates readily in tissues. A large DDE/ $/ 2 D D T$ value suggests that the DDT has been in the system for a relatively long time, while a small ratio suggests relatively recent input of DDT into the system. For a more thorough discussion of DDT and its metabolites refer to Becker et al. (1992). In Table 5, the ratio of the concentrations of 4,4'-DDE to $\Sigma D D T$ in the blubber of the belukha whales from Point Hope and Point Lay are compared to results reported for this species from Canada (Muir et al., 1990), western Greenland (Stern et al., 1994) and results previously reported for AMMTAP pinnipeds (Becker et al., 1992; Schantz et al., 1993). The 4,4'$\mathrm{DDE} / \Sigma \mathrm{DDT}$ in blubber of male and female belukha whales from the same locations are similar and there appears to be little difference between locations, even when including the non-Arctic animals from the St. Lawrence River Estuary. As one might expect, the open-ocean northern fur seals have 4,4'-DDE/ $\sum$ DDT values approaching 1 , as do the ringed seals from Barrow, which may be year-round residents. The ratios for the ringed seals from Norton Sound (Nome) varied more widely; however, as there are data for only two northern fur seals and two ringed seals, it is difficult to draw any conclusions.

In Figures 3 and 4, $\Sigma$ chlordane and $\Sigma$ toxaphene concentrations in blubber of the AMMTAP belukha whales are compared to post-1980 published values for other Arctic marine mammal species. The levels in the AMMTAP animals are similar to those reported for belukha whales and narwhals from the Canadian Arctic (Muir et al., 1992a), for belukha whales from western Greenland (Stern et al., 1994), and for polar bears (Norstrom et al., 1988). Concentrations of $\sum$ chlordane and $\Sigma$ toxaphene in Arctic ringed seals appear to be an order of magnitude lower (Muir et al., 1992b). Although the concentrations of both compounds are somewhat higher in male belukha whales from the Gulf of St. Lawrence than those from the Arctic, the number of males from St. Lawrence is relatively small $(n=4)$ and the differences appear to be slight. The levels in the females from St. Lawrence are also the same order of magnitude as the other belukha whales.

Most of the animals sampled at Point Lay had higher levels of total DDTs, PCBs, chlordanes and toxaphene than the two animals from Point Hope. However, the two Point Hope animals were relatively young females (see Table 3 ). Combining the Point Hope with the Point Lay data (Figure $5 a)$, one can see that the concentrations of these chlorinated hydrocarbons are lower in the females than in the males, and vary more widely for females. The latter might be due to the relatively small number of animals sampled, the wider range of ages for females (Figure 5b), and the ability of reproductive females to eliminate lipophilic contaminants through lactation and parturition. The differences between males and females in total concentrations of DDTs, PCBs, chlordanes and toxaphene are similar to differences reported by Muir et al. (1990) and Stern et al. (1994) for belukha whales from Canada and western Greenland (see Figure 5a).

Both toxaphene and chlordane contribute a greater fraction to the total chlorinated hydrocarbon levels in Arctic biota (including marine mammals) than appears to be the case for temperate regions of the northern hemisphere (Muir et al., 1992b). This is shown in Table 6, where the $\Sigma$ chlordane/ $\Sigma$ PCB of AMMTAP belukha whale blubber is compared to that reported for belukha whales from three regions of Arctic Canada and the St. Lawrence River estuary and from western Greenland. The ratios for the animals from Point Lay and Point Hope are basically the same as those reported for belukha whales sampled at the mouth of the Mackenzie River (Beaufort Sea). This should not be surprising since the animals from the Mackenzie River area are probably from the same population as those sampled at Point Hope and may also be exposed to the same 


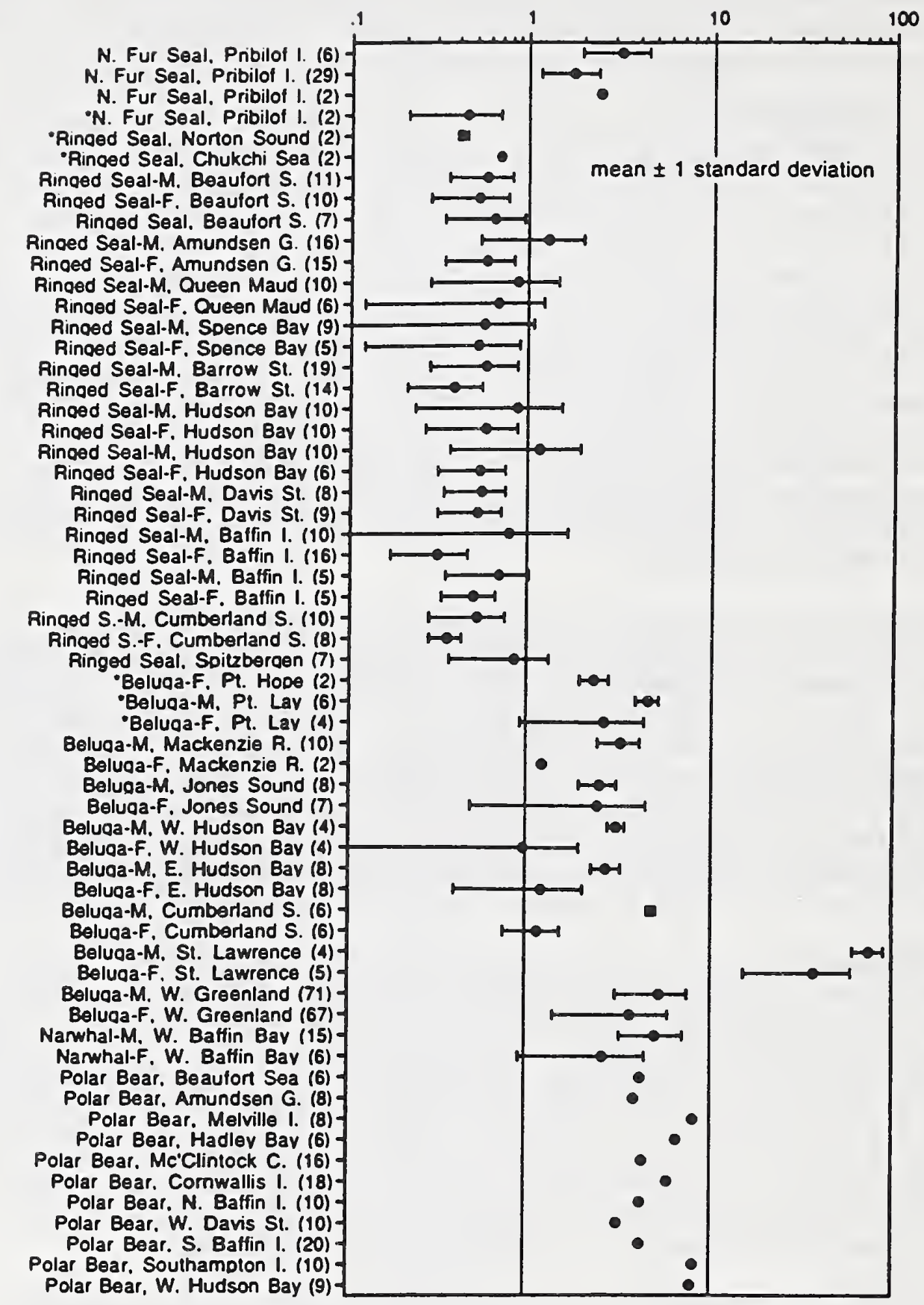

Figure 1. $\quad \sum \mathrm{PCB}$ concentration $(\mu \mathrm{g} / \mathrm{g}$ wet weight) in blubber of Arctic marine mammals. Numbers of animals are in parentheses; male and female animals are designated by $M$ and $F$. AMMTAP data are indicated by an asterisk (*). Other values are from: Kurtz (1987), Calambokidis and Peard (1985), Muir et al. (1990), Muir et al (1992a\&b), Muir et al. (1988a), Addison et al. (1986), Thomas and Hamilton (1988), Oehme et al. (1988), and Stern et al. (1994). Polar bear data are pooled samples (Norstrom et al., 1988). No data published prior to 1980 are included. 


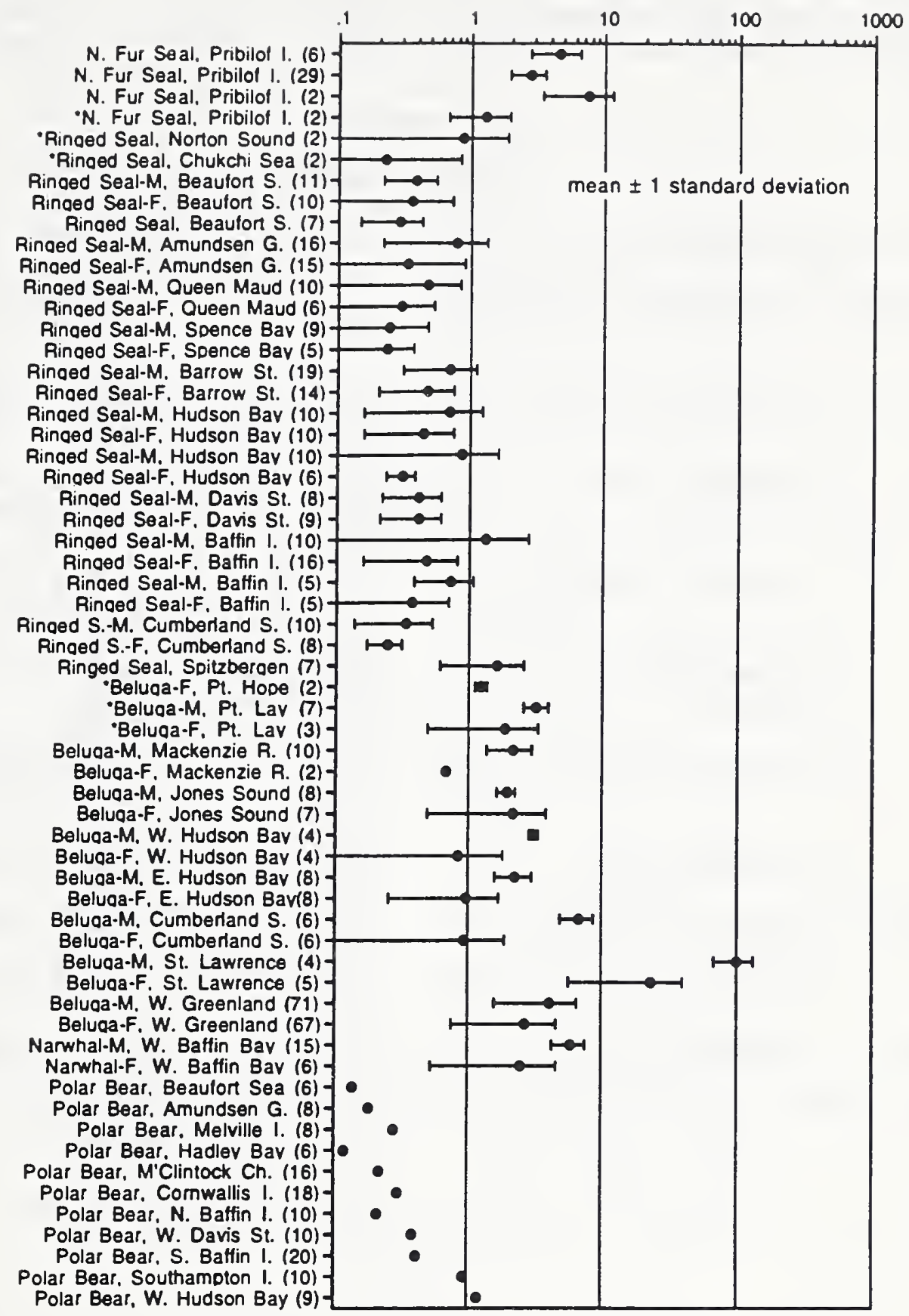

Figure 2. $\Sigma D D T$ concentration ( $\mu \mathrm{g} / \mathrm{g}$ wet weight) in blubber of Arctic marine mammals. Numbers of animals are in parentheses; male and female animals are designated by $M$ and F. AMMTAP data are indicated by an asterisk $(*)$. Other values are from: Kurtz (1987), Calambokidis and Peard (1985), Muir et al. (1990), Muir et al (1992a, b), Muir et al. (1988a), Addison et al. (1986), Thomas and Hamilton (1988) Oehme et al. (1988), and Stern et al. (1994). Polar bear data are pooled samples (Norstrom et al., 1988). No data published prior to 1980 are included. 
Table 5. Ratios of 4,4'DDE to $\Sigma D D T$ in blubber of belukha whales from Point Hope and Point Lay as compared to values reported for belukha whales from Canada, for pinnipeds (AMMTAP data previously reported). Data sources are: 1- Stern et al. (1994); 2 - Muir et al. (1990); 3 Becker et al. (1992) and Schantz et al. (1993). Values are expressed as the mean \pm 1 standard deviation.

Species

Location (Date)

Sex Number

4,4'DDE/LDDT Data Source

\begin{tabular}{|c|c|c|c|c|c|}
\hline \multirow[t]{7}{*}{ Belukha whale } & W. Greenland (1989-90) & $\stackrel{\mathrm{M}}{\mathrm{F}}$ & $\begin{array}{l}71 \\
67\end{array}$ & $\begin{array}{l}0.56 \pm 0.05 \\
0.52 \pm 0.05\end{array}$ & $\begin{array}{l}1 \\
1\end{array}$ \\
\hline & St. Lawrence (1986-87) & $\begin{array}{l}\mathrm{M} \\
\mathrm{F}\end{array}$ & $\begin{array}{l}4 \\
5\end{array}$ & $\begin{array}{l}0.66 \pm 0.06 \\
0.56 \pm 0.09\end{array}$ & 2 \\
\hline & Hudson Bay (1986) & $\begin{array}{l}\mathrm{M} \\
\mathrm{F}\end{array}$ & $\begin{array}{l}4 \\
4\end{array}$ & $\begin{array}{l}0.57 \pm 0.04 \\
0.57 \pm 0.04\end{array}$ & $\begin{array}{l}2 \\
2\end{array}$ \\
\hline & Jones Sound (1986) & $\begin{array}{l}\mathrm{M} \\
\mathrm{F}\end{array}$ & $\begin{array}{l}8 \\
7\end{array}$ & $\begin{array}{l}0.55 \pm 0.04 \\
0.56 \pm 0.05\end{array}$ & $\begin{array}{l}2 \\
2\end{array}$ \\
\hline & $\begin{array}{l}\text { Mackenzie Bay } \\
(1983,87)\end{array}$ & $\begin{array}{l}\mathrm{M} \\
\mathrm{F}\end{array}$ & $\begin{array}{r}10 \\
2\end{array}$ & $\begin{array}{l}0.47 \pm 0.15 \\
0.50\end{array}$ & 2 \\
\hline & Point Lay (1990) & $\begin{array}{l}\mathrm{M} \\
\mathrm{F}\end{array}$ & $\begin{array}{l}7 \\
3\end{array}$ & $\begin{array}{l}0.58 \pm 0.02 \\
0.48 \pm 0.18\end{array}$ & \\
\hline & Point Hope (1989) & $\mathrm{F}$ & 2 & $0.53 \pm 0.01$ & \\
\hline \multirow[t]{2}{*}{ Ringed Seal } & Barrow, AK (1988) & M & 2 & $0.85 \pm 0.10$ & 3 \\
\hline & Nome, AK (1989) & M & 2 & $0.34 \pm 0.25$ & 3 \\
\hline N. Fur Seal & St. Paul I., AK (1987) & M & 2 & $0.93 \pm 0.06$ & 3 \\
\hline
\end{tabular}




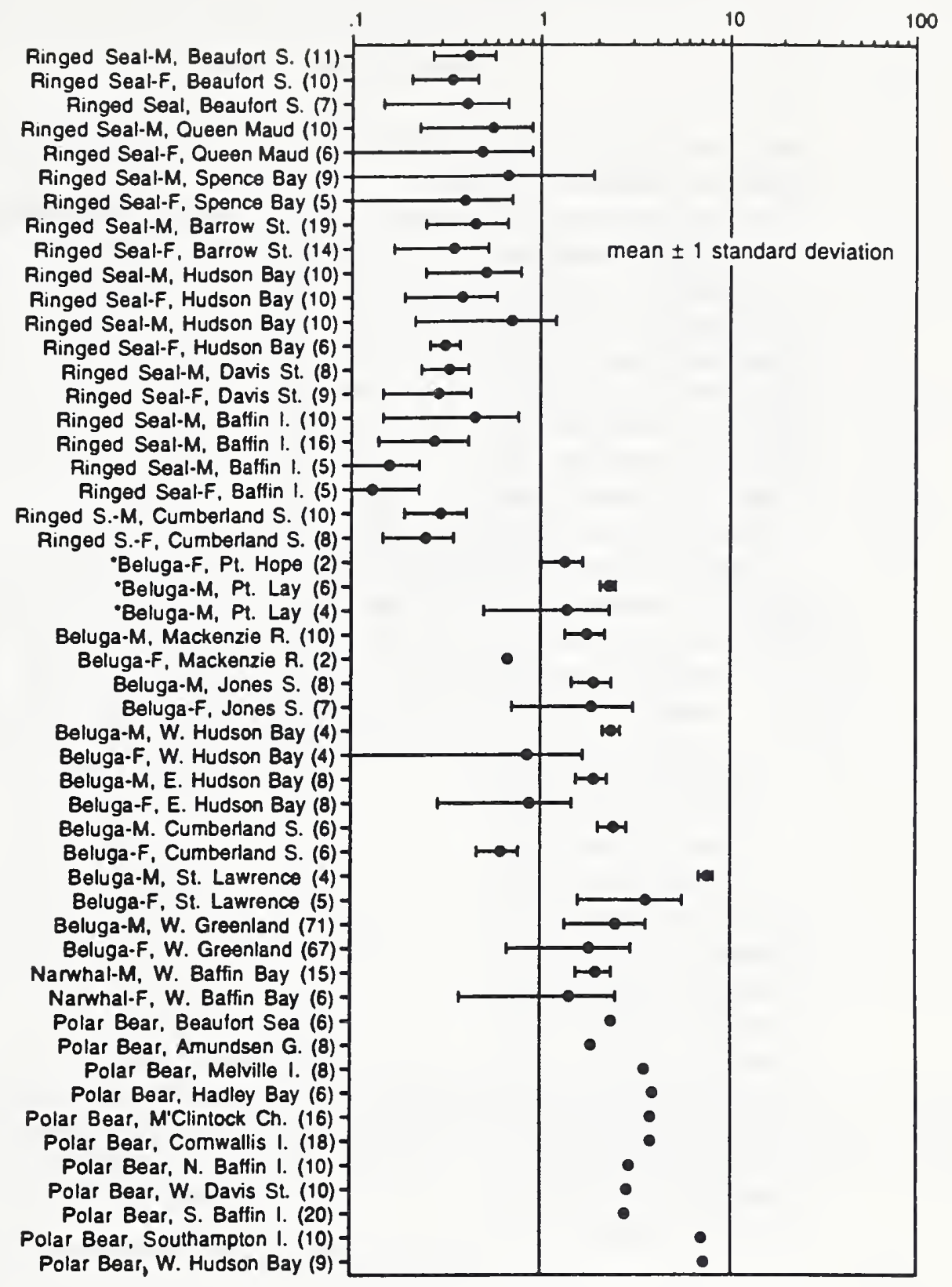

Figure 3. $\Sigma$ Chlordane concentration $(\mu \mathrm{g} / \mathrm{g}$ wet weight) in blubber of Arctic marine mammals. Numbers of animals are in parentheses; male and female animals are designated by $M$ and $F$. AMMTAP data are indicated by an asterisk $\left({ }^{*}\right)$. Ringed seal data is from Muir et al. (1992b) and Thomas and Hamilton (1988); additional belukha and narwhal data is from Muir et al. (1992a) and Stern et al. (1994); polar bear data is from pooled samples (Norstrom et al., 1988). No data published prior to 1980 are included. 


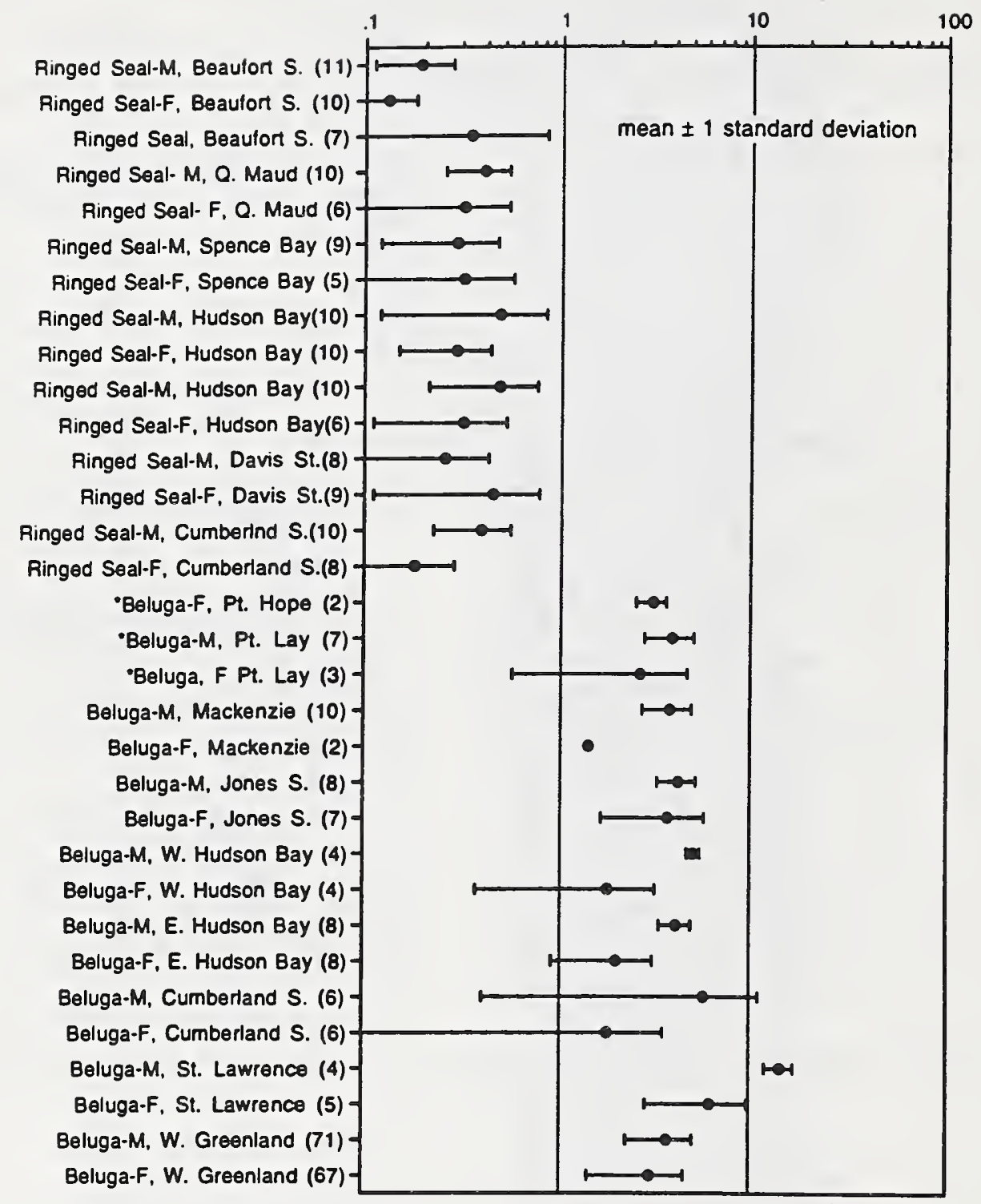

Figure 4. Toxaphene concentration ( $\mu \mathrm{g} / \mathrm{g}$ wet weight) in blubber of Arctic marine mammals. Numbers of animals are in parentheses; male and female animals are designated by $M$ and $F$. AMMTAP data are indicated by an asterisk (*). Ringed seal data is from Muir et al. (1992b); additional belukha and narwhal data is from Muir et al. (1992a). No data published prior to 1980 are included. 


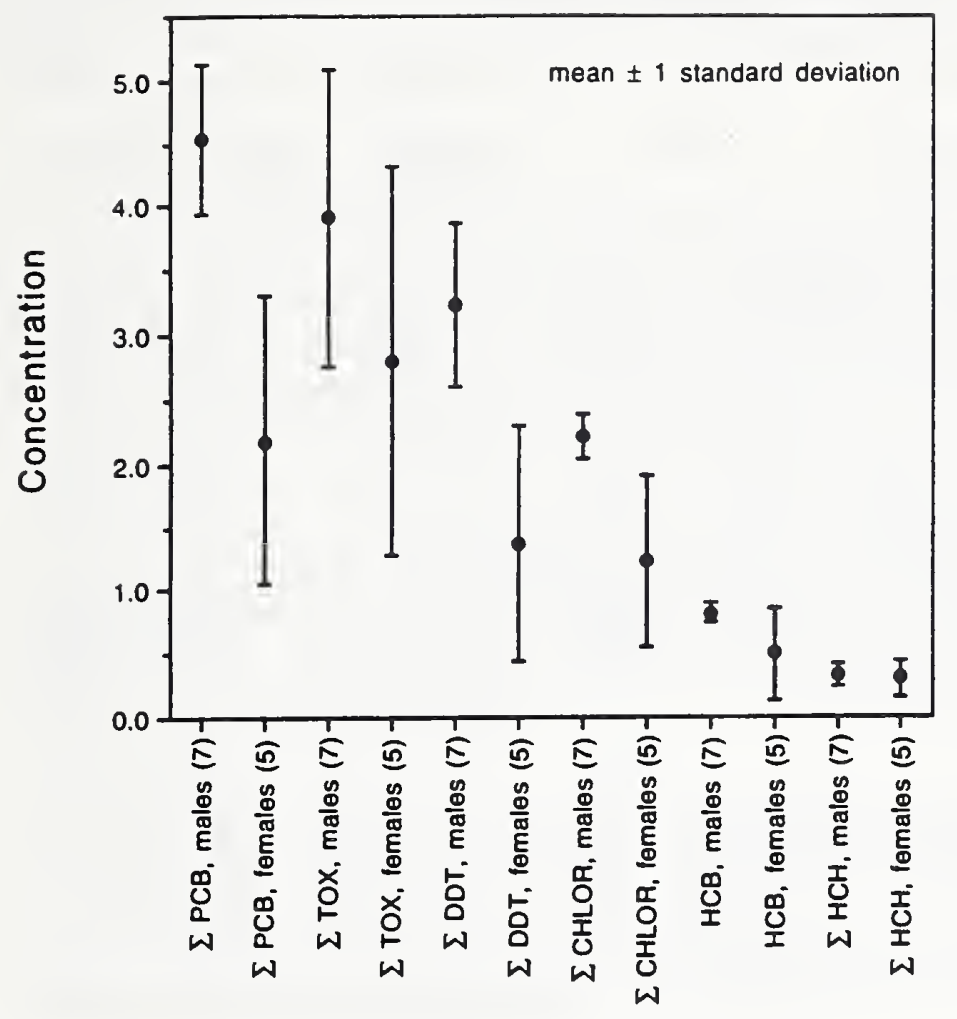

a.

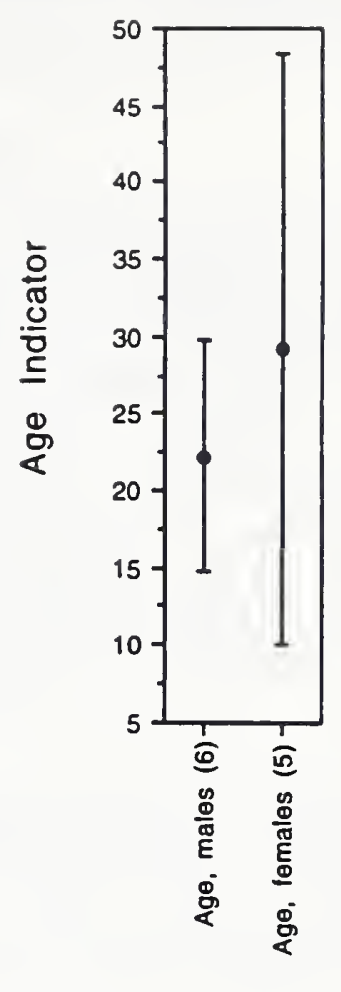

b.

Figure 5. Concentration of PCBs and chlorinated pesticides in blubber and relative age distribution of male and female belukhas sampled by the AMMTAP. Concentrations are in $\mu \mathrm{g} / \mathrm{g}$ wet weight. Age indicator is the number of growth layer groups in longitudinal tooth sections. It is believed that two layers are laid down annually. 
Table 6. Ratios of $\Sigma$ chlordane to $\Sigma$ PCBs in blubber of belukha whales from Point Hope and Point Lay as compared to values reported in Muir et al. (1990) for belukha whales from Canada and in Stern et al. (1994) for belukha whales from West Greenland. Values are expressed as the mean \pm 1 standard deviation.

Species

Location (Date)

Sex

Number

$\Sigma \mathrm{CHLOR} / \Sigma \mathrm{PCB}$

From Stern et al. (1994): $\quad$ W. Greenland (1989-90)

$\begin{array}{lll}\mathrm{M} & 71 & 0.45 \\ \mathrm{~F} & 67 & 0.48\end{array}$

From Muir et al. (1990):

St. Lawrence (1986-
Hudson Bay (1986)

$\begin{array}{ll}M & 4 \\ \mathrm{~F} & 5\end{array}$

$0.10 \pm 0.01$

$\mathrm{F}$

$0.10 \pm 0.02$

Jones Sound (1986)

$\begin{array}{ll}\text { M } & 4 \\ \text { F } & 4\end{array}$

$0.70 \pm 0.11$

$0.82 \pm 0.19$

$\begin{array}{ll}\text { M } & 8 \\ \mathrm{~F} & 7\end{array}$

$0.76 \pm 0.22$

F

$0.84 \pm 0.28$

Beaufort Sea $(1983,1987)$

$\begin{array}{lll}\text { M } & 10 & 0.53 \pm 0.04 \\ \text { F } & 1 & 0.55\end{array}$

This report:

Point Lay (1990)

Point Hope (1989)

M

F 2

$0.50 \pm 0.05$

$0.53 \pm 0.06$

$0.55 \pm 0.04$ 
environment as the Point Lay animals during the winter in the Bering Sea. Although the Arctic animals from Hudson Bay and Jones Sound had much higher ratios, belukha whales from western Greenland had ratios similar to belukha whales from Alaska and the Western Arctic of Canada. The lowest ratios were observed for animals from the lower latitudes of the St. Lawrence River estuary reflecting the larger contribution of chlordane to the chlorinated hydrocarbon burden for Arctic animals.

\section{Intercomparison Data}

Since NIST, DFO, and the University of Ulm provided results for chlorinated hydrocarbons in belukha whale blubber samples from the AMMTAP, an intercomparison exercise was conducted to determine the comparability of results from these three laboratories. DFO also participates in the quality assurance component of the Marine Mammal Health and Stranding Response Program sponsored by the National Marine Fisheries Service (Wise, 1993; Wise et al., 1993).

A pilot whale blubber QA material (Wise et al., 1993) was distributed as an intercomparison exercise among the three laboratories, and SRM 1588 Organics in Cod Liver Oil was analyzed as a control sample by each laboratory. The results from each of the three laboratories for the analyses of SRM 1588 and the QA whale blubber are shown in Tables B-1 and B-2, respectively. The agreement of the results among the laboratories is very good as is the agreement with the certified concentrations for SRM 1588.

Subsamples of four belukha whale blubber samples were analyzed at NIST, DFO, and the University of Ulm. The results of this three-laboratory intercomparison exercise are summarized in Appendix B, Table B-3. Four of the samples in this first intercomparison exercise were those previously analyzed at NIST and reported in Becker et al. (1992), and these results are denoted as NIST-I in Table B-3. Two of these four samples were re-analyzed at NIST in 1992 and the results are denoted as NIST-II in Table B-3.

In general the results among the three laboratories are within $25 \%$. The largest differences are for the NIST-I results which were often higher suggesting possible coelution of compounds of interest. For example, PCB 28 and PCB 31, as well as PCB 105 and PCB 132, coeluted in the NIST-I data set but not in the more recent NIST-II or the DFO and Ulm results. PCB 66 and PCB 95 coelute in the NIST-I and DFO results but not in the NIST-II and Ulm data. When only the NIST-II results are compared, the agreement among the three laboratories is very good, particularly for the major PCB congeners and chlorinated pesticides.

\section{Inorganic Constituents}

Results of the inorganic analyses of liver tissue specimens collected from the Norton Sound pinnipeds, belukha whales, and bowhead whales are presented in Appendix C. These results include many elements that are not determined routinely in marine mammal tissues. Concentration values for 35 elements are given, including several trace elements that are considered to be potentially toxic at elevated levels and in the appropriate chemical forms. The following elements were at or below detection limit: gold, barium, cerium, europium, hafnium, lanthanum, scandium, tin, strontium, tantalum, terbium, thorium, and uranium. (See Appendix C, Table C-1.)

For direct comparison of concentration values obtained using the same analytical techniques on similar matrices, the Project has available results of element analyses by NIST of liver tissue from four harbor porpoise and eight pilot whales sampled for the NMMTB, plus the values previously reported by AMMTAP for northern fur seals and ringed seals (Becker et al., 1992; Zeisler et al., 1993). In addition, Wagemann et al. (1990) have recently published trace element data on belukha 
whales from five locations in the Canadian Arctic and the St. Lawrence Estuary, which allows for a comparison with different populations of this species across the northern part of North America. Results for arsenic, cadmium, copper, mercury, selenium, silver, vanadium, and zinc are discussed below.

\section{Arsenic}

Arsenic concentrations in liver tissue of animals sampled by AMMTAP and NMMTB are compared in Figure 6. Both the pilot whales and harbor porpoise contain somewhat higher levels than the belukha whales and basically the same concentrations as the bowhead whales, while the ringed seals from Norton Sound show substantially elevated levels (six of the fourteen animals have levels $>1 \mu \mathrm{g} / \mathrm{g}$ and two have levels $>2 \mu \mathrm{g} / \mathrm{g}$ wet weight). Although the database for arsenic concentration in marine mammals is limited, the hepatic arsenic concentrations for these two ringed seals are an order of magnitude higher than levels reported for walrus, northern fur seal, other Arctic ringed seals, belukha whales, bowhead whales, pilot whales, gray whales, and harbor porpoise (see Figure 7). Excluding one pilot whale, whose liver contained slightly above $1.0 \mu \mathrm{g} / \mathrm{g}$ wet weight, all other values for the NMMTB pilot whales and harbor porpoise were $\leq 0.5 \mu \mathrm{g} / \mathrm{g}$.

Thompson (1990) indicates that concentrations of arsenic in liver tissue of birds and mammals rarely exceed $1.0 \mu \mathrm{g} / \mathrm{g}$ wet weight. Marine mammal tissues, however, may potentially contain higher levels. Marine organisms generally contain higher amounts of arsenic than terrestrial or freshwater organisms and the majority of this arsenic is in organic rather than inorganic form. Tissues with high lipid content generally have the highest concentrations. These include liver, fat, and muscle. It appears that organic forms of arsenic in marine food webs are derived from in vivo synthesis by primary producers and are efficiently transferred along the marine food chain (Wrench et al., 1979; Maher, 1985). Organic forms include the tetramethylarsonium ion, dimethylarsinylethanol, trimethylarsoniumlactate, arsenic-containing sugars and phospholipids, arsenocholine, and arsenobetaine, $\left[\left(\mathrm{CH}_{3}\right)_{3} \mathrm{AsCH}_{2} \mathrm{OOH}\right]$ the dominant form in marine animals (Edmonds and Francesconi, 1993).

The toxicity of both the organic and inorganic forms of arsenic is highly valence state dependent: trivalent arsenic is much more toxic than pentavalent arsenic. For example, Eisler (1988) gives the following order of toxicity for arsenic compounds, from greatest to least toxic: arsines $>$ inorganic arsenites $>$ organic trivalent compounds (arsenoxides) $>$ inorganic arsenates $>$ organic pentavalent compounds (such as arsenobetaine) $>$ arsonium compounds $>$ elemental arsenic. Although Vahter and Envall (1983) have shown that arsenate may be reduced to the more toxic arsenite in mice and rabbits, it appears that organoarsenicals are not converted metabolically to the more toxic inorganic species during their passage through animal systems (Soto et al., 1993). Due to the valence state of the arsenic and its organic nature, one would expect arsenobetaine to be of little toxic concern and this seems to be the case. The potential risks associated with consumption of seafood containing arsenobetaine are very minor (Edmonds and Francesconi, 1993). It is relatively nontoxic, rapidly absorbed by the gastrointestinal tract and rapidly excreted in urine, without metabolism (Kaise et al., 1985). It is not mutagenic in the Ames test, has no mutagenic action, and shows no synergism or antagonism with other contaminants (Jongen et al., 1985).

Crustacean tissues sold for food and taken in U.S. coastal waters usually contain total arsenic levels of $3-10 \mu \mathrm{g} / \mathrm{g}$ wet weight (Hall et al., 1978) or $1-100 \mu \mathrm{g} / \mathrm{g}$ dry weight (Fowler and Unlu 1978), and somewhat higher levels have been reported in finfish and mollusks. Arsenic levels in finfish range from about $2-5 \mu \mathrm{g} / \mathrm{g}$ wet weight (Eisler, 1988). The highest arsenic values in marine mammals .were reported for fin whale blubber oil, $1.8 \mu \mathrm{g} / \mathrm{g}$ wet weight (Jenkins, 1980), and for cetaceans, $0.6-2.8 \mu \mathrm{g} / \mathrm{g}$ wet weight (Eisler, 1981). However, of all the values for arsenic in liver tissue published, none were as high as the levels found in the livers of the ringed seals from Norton Sound. 


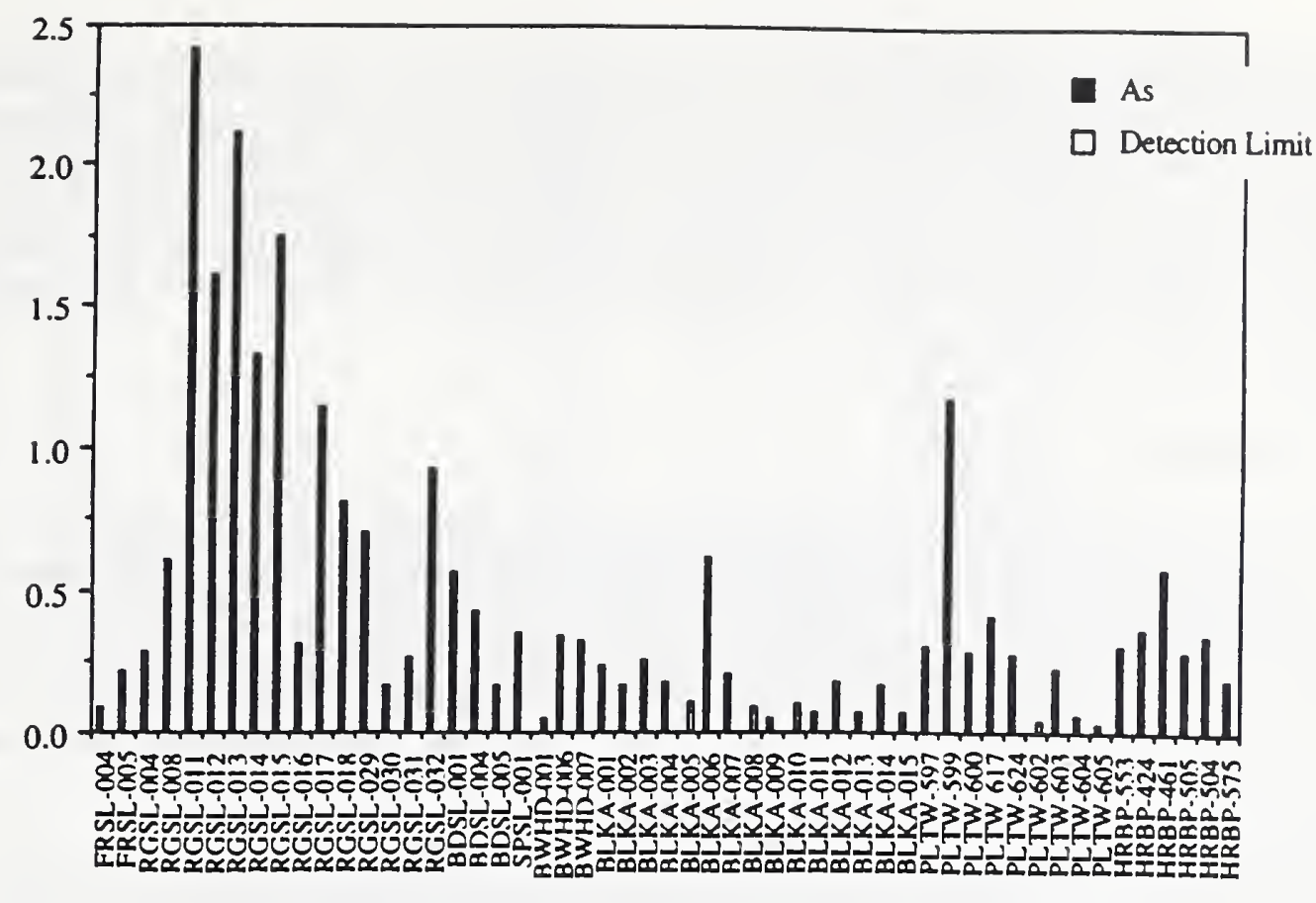

Figure 6. Arsenic concentration ( $\mu \mathrm{g} / \mathrm{g}$ wet weight) in AMMTAP and NMMTB liver samples. AMMTAP animals: FRSL $=$ northern fur seal; RGSL $=$ ringed seal; $B D S L=$ bearded seal; SPSL = spotted seal $; \mathrm{BWHD}=$ bowhead whale; $\mathrm{BLKA}=$ belukha whale. NMMTB animals: PLTW = pilot whale and HRBP = harbor porpoise.

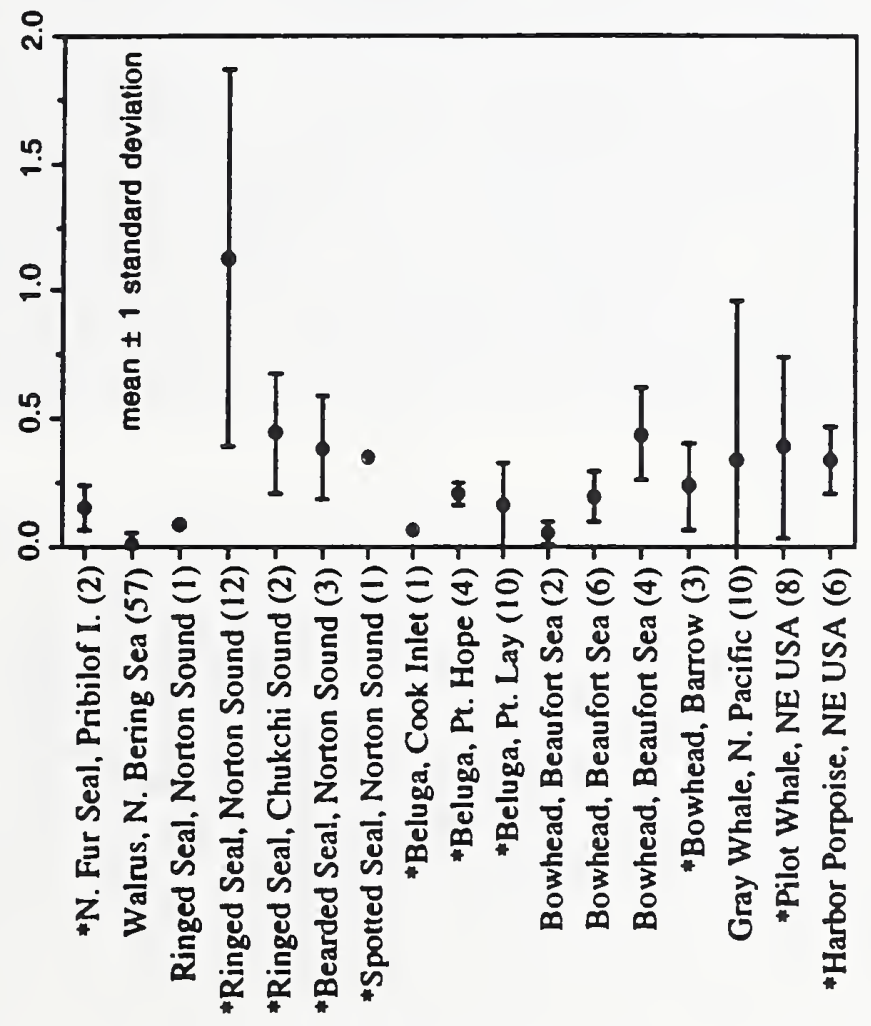

Figure 7. Comparison of arsenic concentrations $(\mu \mathrm{g} / \mathrm{g}$ dry weight) in marine mammal liver. AMMTAP and NMMTB data are indicated by an asterisk (*). Other values are: walrus from Taylor et al. (1989), ringed seal from AT (1988), bowhead from Byme et al. (1985) and Bratton et al. (1993), and gray whale from Varanasi et al. (1993). Numbers of animals are in parentheses. 
We do not know how much of the arsenic in the ringed seal liver was present as arsenobetaine, since we did not analyze for this compound. Bratton et al. (1993) in their study of bowhead whales found that in the animal with the highest liver concentration of arsenic $(0.44 \mu \mathrm{g} / \mathrm{g}$ wet weight), $98 \%$ was in the form of arsenobetaine. Edmonds and Francesconi (1993) in their review of the data on arsenic levels in fish, crustaceans, and mollusks reported that the proportion of inorganic arsenic ranged from about $1 \%$ at very low total arsenic concentrations to about $0.5 \%$ at total arsenic levels of about $20 \mu \mathrm{g} / \mathrm{g}$ wet weight.

\section{Cadmium}

Cadmium is not easily regulated metabolically and may increase in animal tissues with age. It is not eliminated by females during lactation so that little difference is observed between the levels found in males and females. The highest cadmium concentrations in liver tissue from the AMMTAP and NMMTB animals were for northern fur seals, bowhead whales, and pilot whales, with two of the ringed seals from Norton Sound having somewhat elevated levels (Figure 8). Levels in the harbor porpoise were particularly low. The pilot whale and harbor porpoise data are consistent with cadmium concentration values reported by other researchers for these species (Falconer et al., 1983 and Meador et al., 1993).

Cadmium values for the belukha liver tissue (Figure 8) were relatively low and comparable to those previously reported for ringed seals from the Chukchi Sea (Becker et al., 1992; Zeisler et al., 1993). In order to compare the AMMTAP belukha whale data with those reported for this species by Wagemann et al. (1990), wet weight values were converted to $\mu \mathrm{g} / \mathrm{g}$ of dry weight. These comparisons are shown in Figure 9. The single whale from Cook Inlet had lower hepatic cadmium concentrations than the hepatic concentrations of whales from Point Hope and Point Lay and than levels reported for the other whales from the Canadian Arctic. The cadmium data from the Point Hope and Point Lay animals are similar to values reported by Wagemann et al. (1990) for belukha whales sampled at the mouth of the Mackenzie River. This is expected as the Point Hope and Mackenzie River whales are probably from the same population. A much wider variation in hepatic cadmium concentrations was observed for the whales from the eastern Canadian Arctic (Pangnirtung and Eskimo Point). Norstrom et al. (1986) and Wagemann (1993) found that hepatic $\mathrm{Cd}$ concentrations were higher in animals from the western Arctic as compared with those from the eastern Arctic. This may also be the case for belukha whales, as indicated by the data shown in Figure 9. The belukha whales from the Gulf of St. Lawrence, which are highly contaminated with organochlorines and have elevated mercury levels, had very low cadmium levels, as low as that for the belukha whale from Cook Inlet.

Although we only have data from three bowhead whales, the cadmium concentrations in the livers of these animals ranged from below the detection limit of $0.34 \mu \mathrm{g} / \mathrm{g}$ (wet weight) for a small immature female to a value of $19.7 \mu \mathrm{g} / \mathrm{g}$ wet weight for a large mature male. The high values are similar to those reported for northern fur seal and are comparable with values reported by USFWS for walrus from the Bering and Chukchi seas (Warburton and Seagars, 1993). The USFWS has been monitoring heavy metals in walrus because of elevated levels of cadmium in liver and kidney of these animals. The USFWS recently reported hepatic cadmium concentrations for walrus ranging from $0.96-86.7 \mu \mathrm{g} / \mathrm{g}$ dry weight, with a mean of $27.6 \pm 16.9 \mu \mathrm{g} / \mathrm{g}$ (one standard deviation). The cadmium concentrations for the three bowhead whale livers expressed on the basis of dry weight are: $\leq 1.41,68.2$, and $81.7 \mu \mathrm{g} / \mathrm{g}$. Elevated levels of cadmium in the liver and kidney tissue of bowhead whales were previously reported by Byrne et al. (1985) and Bratton et al. (1993). 


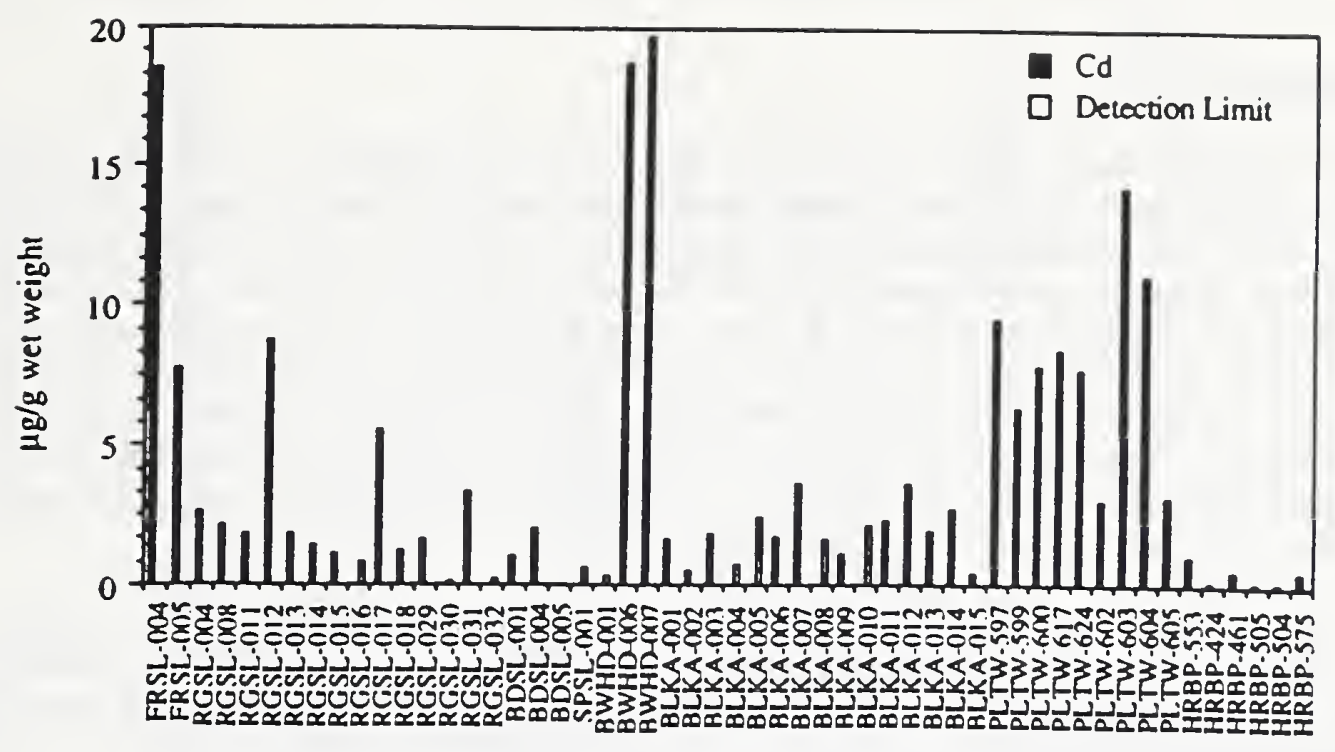

Figure 8. Cadmium concentration ( $\mu \mathrm{g} / \mathrm{g}$ wet weight) in AMMTAP and NMMTB liver samples. AMMTAP animals: FRSL $=$ northern fur seal; $R G S L=$ ringed seal; $B D S L=$ bearded seal; SPSL = spotted seal; $\mathrm{BWHD}=$ bowhead whale; $\mathrm{BLKA}=$ belukha whale. NMMTB animals: PLTW = pilot whale and HRBP = harbor porpoise.

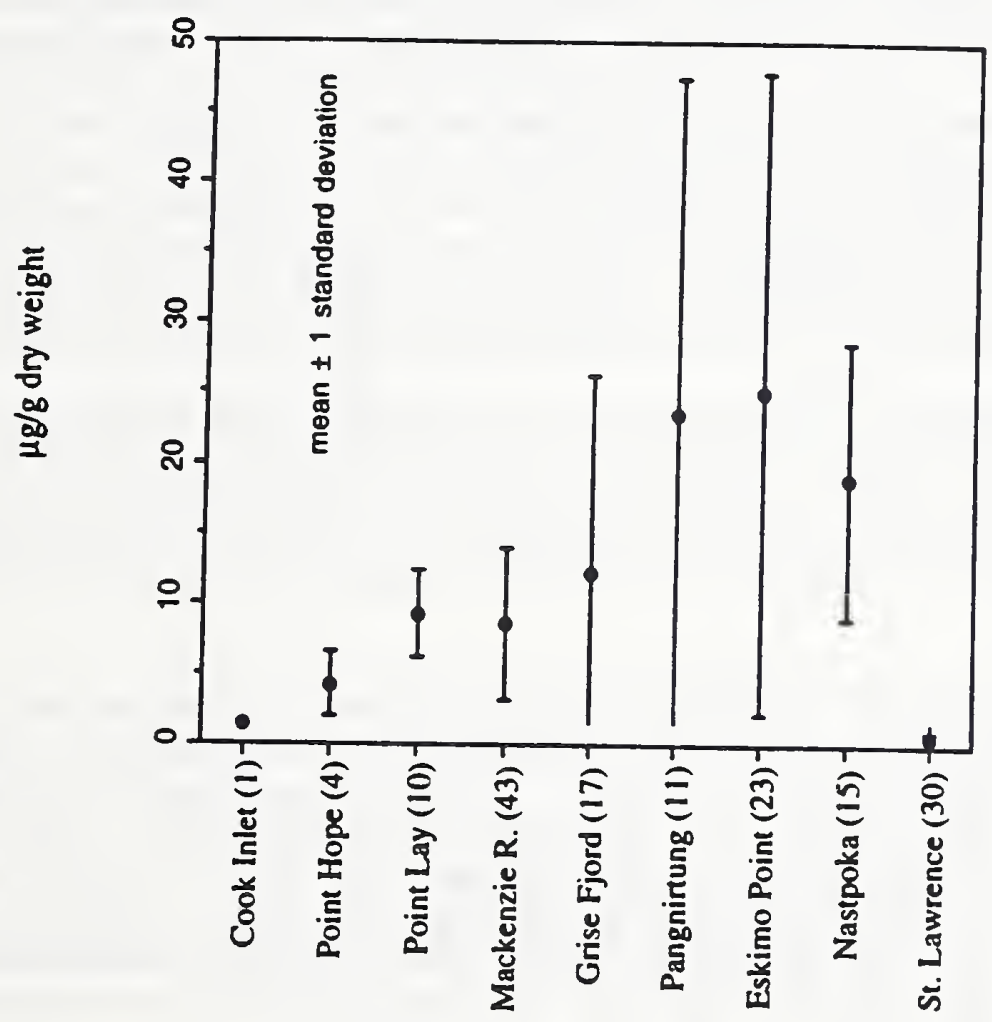

Figure 9. Comparison of cadmium concentrations ( $\mu \mathrm{g} / \mathrm{g}$ dry weight) in liver of belukha whales from Alaska and Canada. Locations are presented from west to east (left to right); numbers of animals are in parentheses. Data for the six Canadian locations are from Wagemann et al. (1990). 


\section{Copper}

Copper is an essential element that is regulated metabolically in vertebrates. The highest levels in mammals are usually found in the liver. Most marine mammal liver tissues contain $<20 \mu \mathrm{g} / \mathrm{g}$ wet weight. Hepatic copper concentrations were higher for belukha whales, northern fur seals, ringed seals, and harbor porpoise as compared with the concentrations for bowhead whales and pilot whales (see Figure 10). McClurg (1984) reported very high copper levels in liver of Ross seal from the Antarctic and related this to the seal's prey; this may also be the case for the belukha whales and harbor porpoise. Since copper is metabolically regulated, accumulation with age may not occur. In fact, the highest copper levels reported have been for young animals. Wagemann et al. (1983) reported that copper concentration was negatively correlated with length for narwhals and Honda et al. (1983) found the same for striped dolphin.

In Figure 11 the copper concentrations in liver tissue of the AMMTAP belukha whales are compared with those reported by Wagemann et al. (1990) for animals from six locations in Canada. The one belukha whale from Cook Inlet had a relatively high hepatic copper concentration while the whales from Point Hope and Point Lay had concentrations similar to those for whales from the western Canadian Arctic.

\section{Mercury}

Similar to cadmium, mercury accumulates with age. Females can eliminate some forms of this element through lactation and parturition; therefore, mature males often have higher levels of mercury than females. The highest levels of mercury are usually found in the liver, with a large proportion in the relatively non-toxic inorganic form. The percentage of the more toxic organic mercury (methylmercury) varies based on age and the amount of total mercury. Methylmercury is probably the form acquired from the food web. The highest percentage of organic mercury in liver is generally associated with the lowest total mercury levels, and the lowest percentage of organic mercury $(\leq 3 \%)$ is usually associated with the highest total levels. The highest concentrations of organic mercury in marine mammal liver tissue are rarely above $2 \mu \mathrm{g} / \mathrm{g}$ wet weight. Some marine mammals may have the ability to demethylate the organic form and sequester it in the liver in a nontoxic form. However, the ability of new-born and young animals to do this is probably limited.

The highest values of total mercury in liver were found in the belukha whale and pilot whale liver (see Figure 12). The one belukha whale from Cook Inlet had a relatively low hepatic mercury concentration of $2.82 \mu \mathrm{g} / \mathrm{g}$ wet weight. The range for the Point Hope animals was $1.40-10.2$ $\mu \mathrm{g} / \mathrm{g}$ wet weight (mean $=4.73$ ), and for the Point Lay animals, $17.7-72.9 \mu \mathrm{g} / \mathrm{g}$ wet weight (mean $=36.5$ ). The whales from Point Lay were somewhat older that those from Point Hope which may account for this difference.

The total mercury levels in the Point Lay belukha whales were relatively high as compared to those for belukha whales from the Canadian Arctic and are comparable to levels reported by Wagemann et al. (1990) for belukha whales from the Gulf of St. Lawrence (see Figure 13). Comparing animals from five Canadian Arctic locations, Wagemann et al. (1990) reported average hepatic mercury concentrations (in $\mu \mathrm{g} / \mathrm{g}$ dry weight) for belukha whales of $8.27 \pm 7.71 \mu \mathrm{g} / \mathrm{g}$ for animals from Grise Fjord, $44.1 \pm 45.5 \mu \mathrm{g} / \mathrm{g}$ for those from Mackenzie Delta, and $126 \pm 161 \mu \mathrm{g} / \mathrm{g}$ for those from the St. Lawrence area. For comparison, average hepatic mercury concentrations for the AMMTAP belukha whales were $17.1 \pm 13.3$ and $191 \pm 93.2 \mu \mathrm{g} / \mathrm{g}$ dry weight for animals from Point Hope and Point Lay, respectively.

The methylmercury fraction was measured in liver specimens of four belukha whales from Point Hope and two from Point Lay (Becker et al. 1992 and Zeisler et al. 1993). The two animals from Point Lay (BLKA-007 and BLKA-012) had methylmercury values of 2.15 and $0.68 \mu \mathrm{g} / \mathrm{g}$ wet weight, which composed $3 \%$ of the total mercury concentration in the livers of these animals, 


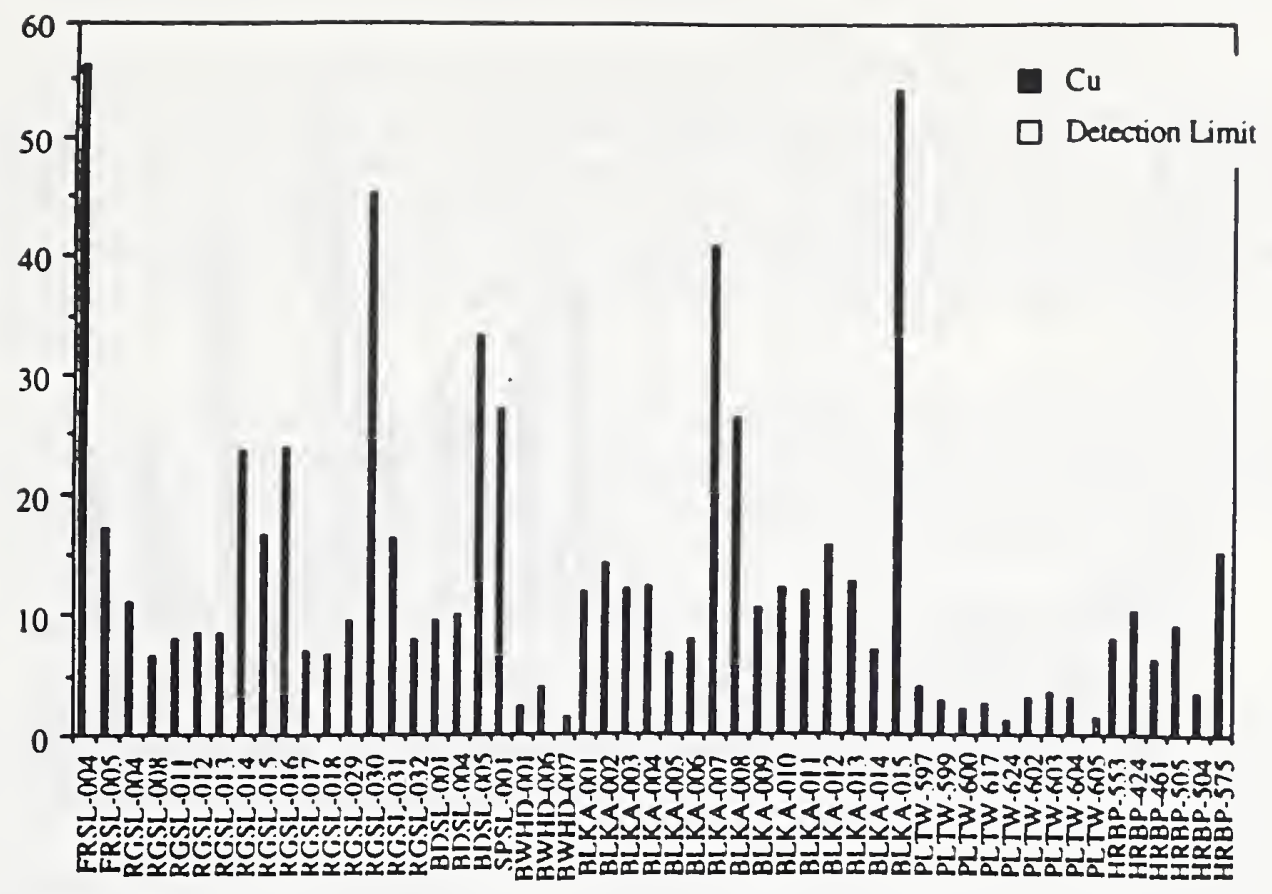

Figure 10. Copper concentration ( $\mu \mathrm{g} / \mathrm{g}$ wet weight) in AMMTAP and NMMTB liver samples. AMMTAP animals: FRSL $=$ northem fur seal; $R G S L=$ ringed seal; $B D S L=$ bearded seal; SPSL = spotted seal; $\mathrm{BWHD}=$ bowhead whale; $\mathrm{BLKA}=$ belukha whale. NMMTB animals: PLTW = pilot whale and HRBP = harbor porpoise.

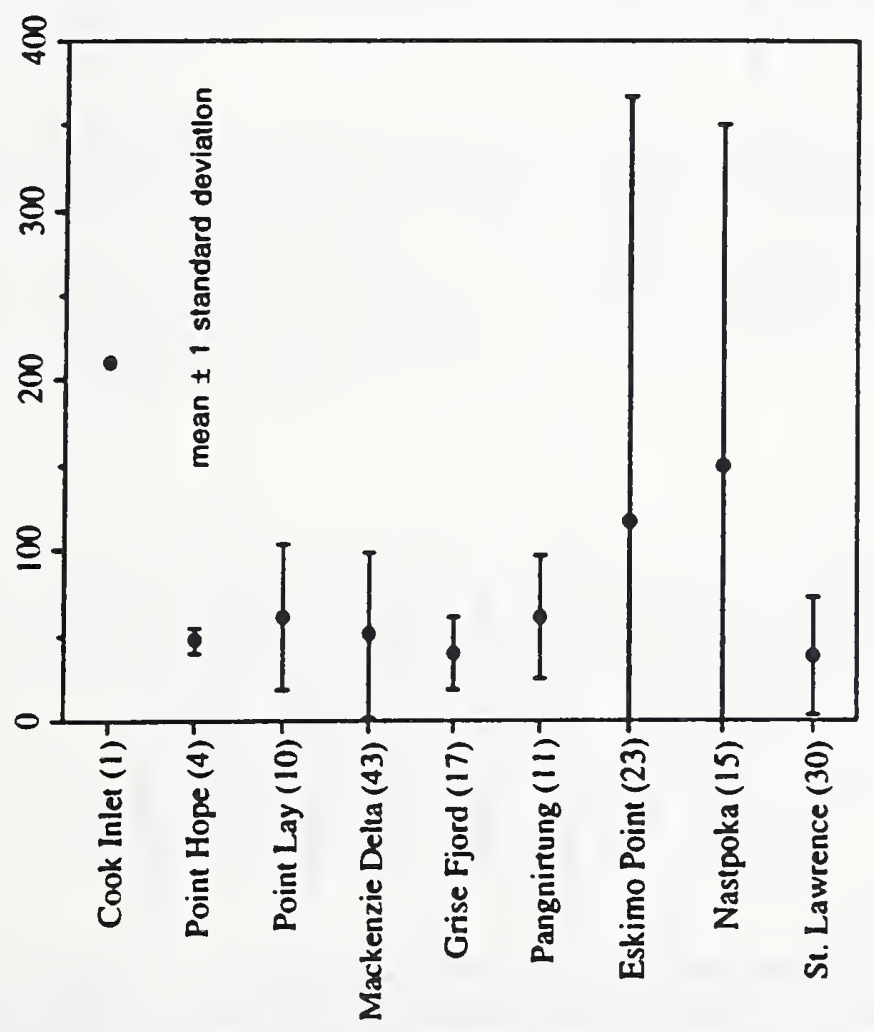

Figure 11. Comparison of copper concentrations ( $\mu \mathrm{g} / \mathrm{g}$ dry weight) in liver of belukha whales from Alaska and Canada. Locations are presented from west to east (left to right); Numbers of animals are in parentheses. Data for the six Canadian locations are from Wagemann et al. (1990). 


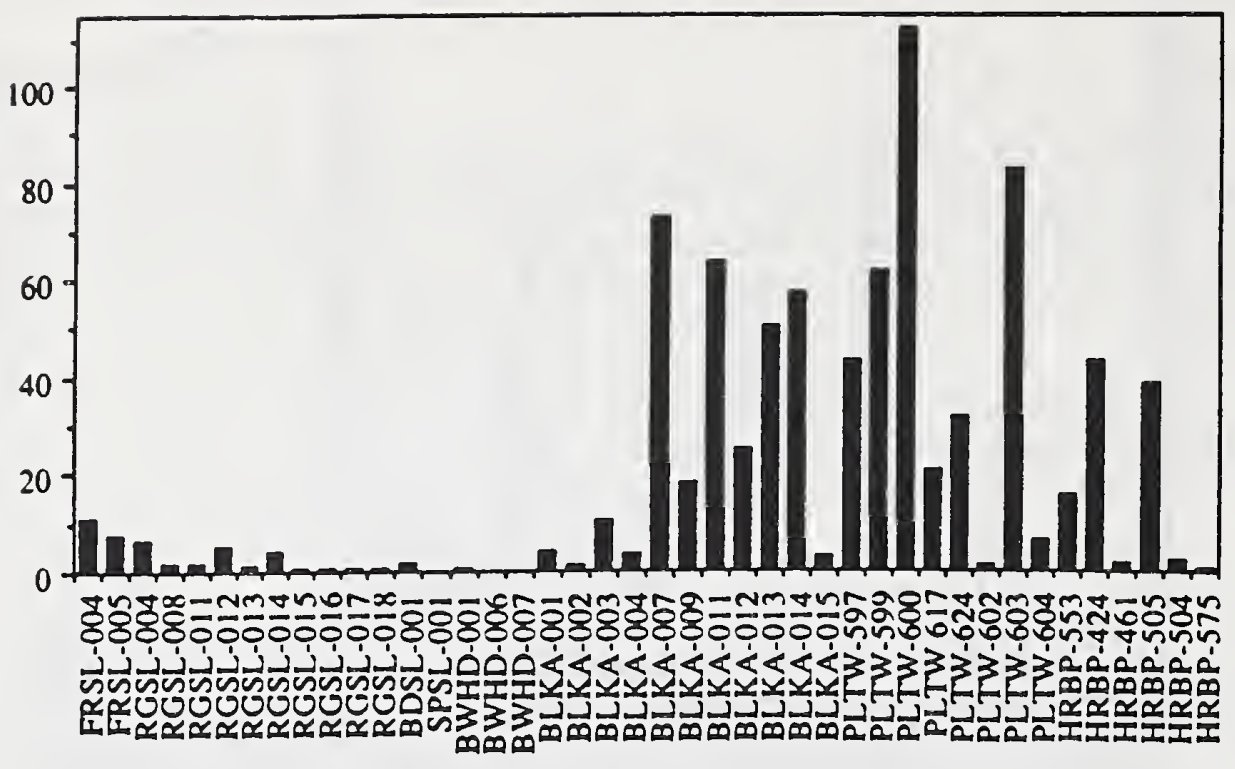

Figure 12. Total mercury concentration ( $\mu \mathrm{g} / \mathrm{g}$ wet weight) in AMMTAP and NMMTB liver samples. AMMTAP animals: FRSL $=$ northern fur seal; $R G S L=$ ringed seal; $B D S L=$ bearded seal; SPSL = spotted seal; $B$ WHD = bowhead whale; BLKA = belukha whale. NMMTB animals: PLTW = pilot whale and HRBP = harbor porpoise.

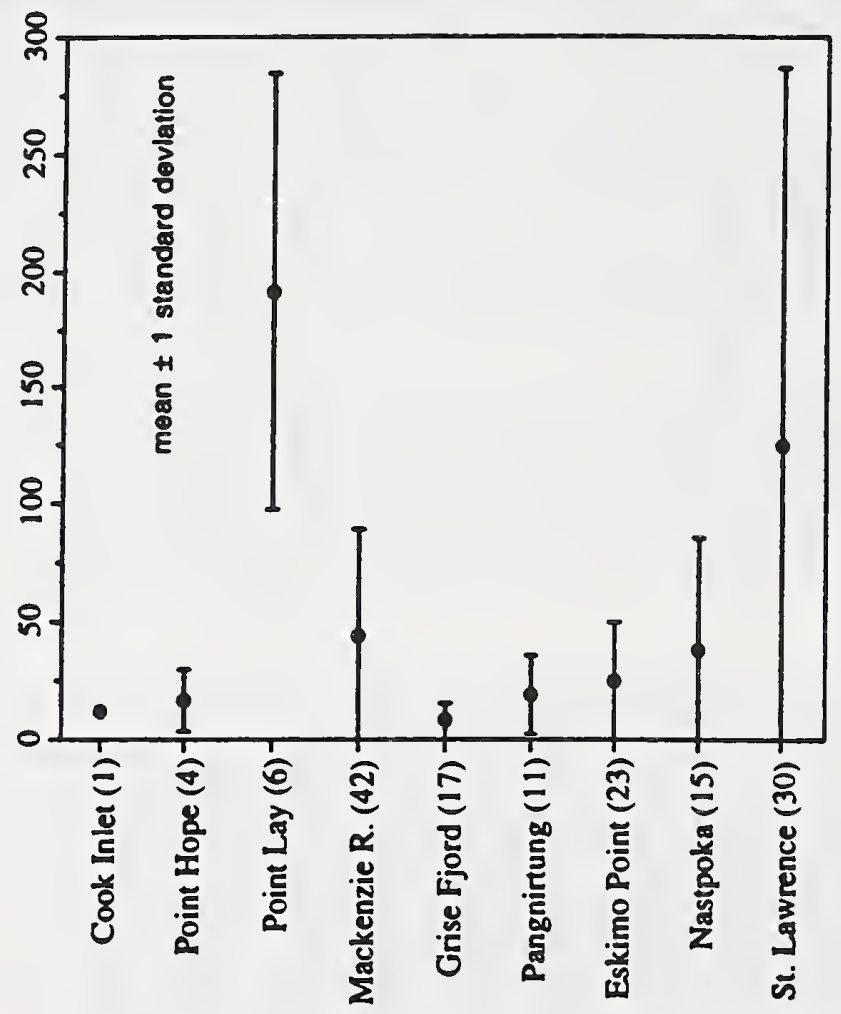

Figure 13. Comparison of total mercury concentrations $(\mu \mathrm{g} / \mathrm{g}$ dry weight) in liver of belukha whales from Alaska and Canada. Locations are presented from west to east (left to right); numbers of animals are in parentheses. Data for the six Canadian locations are from Wagemann et al. (1990). 
while the younger animals from Point Hope had methylmercury values ranging from 0.36 to 0.75 $\mu \mathrm{g} / \mathrm{g}$ wet weight, which composed from $7 \%$ to $29 \%$ of the total mercury in liver tissue. For comparison, Dietz et al. (1990) reported organic mercury concentrations in liver tissues of belukha whales from Greenland $(n=6)$ ranging from $0.33 \mu \mathrm{g} / \mathrm{g}$ wet weight $(39 \%)$ to $1.63 \mu \mathrm{g} / \mathrm{g}$ wet weight $(18 \%)$. They also reported an organic mercury value of $2.15 \mu \mathrm{g} / \mathrm{g}$ wet weight $(6 \%)$ for one ringed seal from Greenland.

The lowest total mercury level was found in the single bowhead whale for which mercury determinations have been made. This value, $0.325 \mu \mathrm{g} / \mathrm{g}$ wet weight, is probably low because this animal was a small immature female, but it is still two orders of magnitude higher than the mercury values reported by Byrne et al. (1985) and Bratton et al. (1993) for bowhead whales.

\section{Selenium}

Selenium is an essential element which has an antidotal action on the toxic effects of mercury, cadmium, arsenic, copper, and thallium either through the formation of insoluble selenide compounds or by simultaneous binding to the toxic metal and to a high molecular weight protein. The presence of metal selenide compounds in cetacean liver has been reported by Martoja and Viale (1977). Selenium is also an integral part of glutathione peroxidase, a mammalian enzyme that, like vitamin $\mathrm{E}$, functions as an antioxidant by preventing lipid peroxidation in tissues, a biochemical path common for many toxic substances and diseases (Rotruck, 1973; Ridlington and Whanger, 1981).

Selenium concentrations in liver tissues of AMMTAP and NMMBT animals are shown in Figure 14 and the average values found in belukha whales from AMMTAP are shown together with the average values found in belukha whales from six Canadian locations are shown in Figure 15. Most values are $\leq 30 \mu \mathrm{g} / \mathrm{g}$ with the exception of the value for one animal (BLKA-007) from Point Lay.

As has been reported by numerous researchers for many animals (both invertebrates and vertebrates), hepatic selenium is positively correlated with hepatic mercury. One would, therefore, expect to find the highest selenium levels in the pilot whale and belukha whale livers, since these contain the highest mercury levels. Results plotted in Figure 18 show that this is the case. The relationship between selenium and mercury can be seen clearly in the data for belukha whales from Cook Inlet, Point Hope, and Point Lay and for the belukha whales described by Wagemann et al. (1990) from the Canadian Arctic (Figures 13 and 15).

\section{Silver}

Silver concentrations in liver tissue of belukha whales (from Cook Inlet, Point Hope and Point Lay) are compared in Figure 16 with values for other AMMTAP and NMMTB animals. In Figure 17, we present an additional comparison with literature values (Byme et al., 1985; Norstrom et al., 1986; Smith, 1986; Varanasi et al., 1993). The concentrations of silver in the belukha whale livers were usually two orders of magnitude higher than those values reported for other marine mammal species from both the Arctic and sub-Arctic. Whereas all other values are $<1 \mu \mathrm{g} / \mathrm{g}$ wet weight, values for the belukha whales are generally $>10 \mu \mathrm{g} / \mathrm{g}$ wet weight. In an additional comparison, the belukha whale liver wet weight values were converted to dry weight concentrations and compared to the data reported by Warburton and Seagars (1993) for walrus from the Bering and Chukchi seas. The mean silver concentration, based on dry weight, in liver tissue of 53 walrus was reported to be $1.49 \mu \mathrm{g} / \mathrm{g}$, with a standard deviation of $1.11 \mu \mathrm{g} / \mathrm{g}$ and values ranging from 0.70 to $5.11 \mu \mathrm{g} / \mathrm{g}$. For the belukha whale livers, the mean silver concentration was $103.1 \mu \mathrm{g} / \mathrm{g}$, with a standard deviation of $98.8 \mu \mathrm{g} / \mathrm{g}$ and values ranged from $23.1-431 \mu \mathrm{g} / \mathrm{g}$, two orders of magnitude higher than those for walrus. 


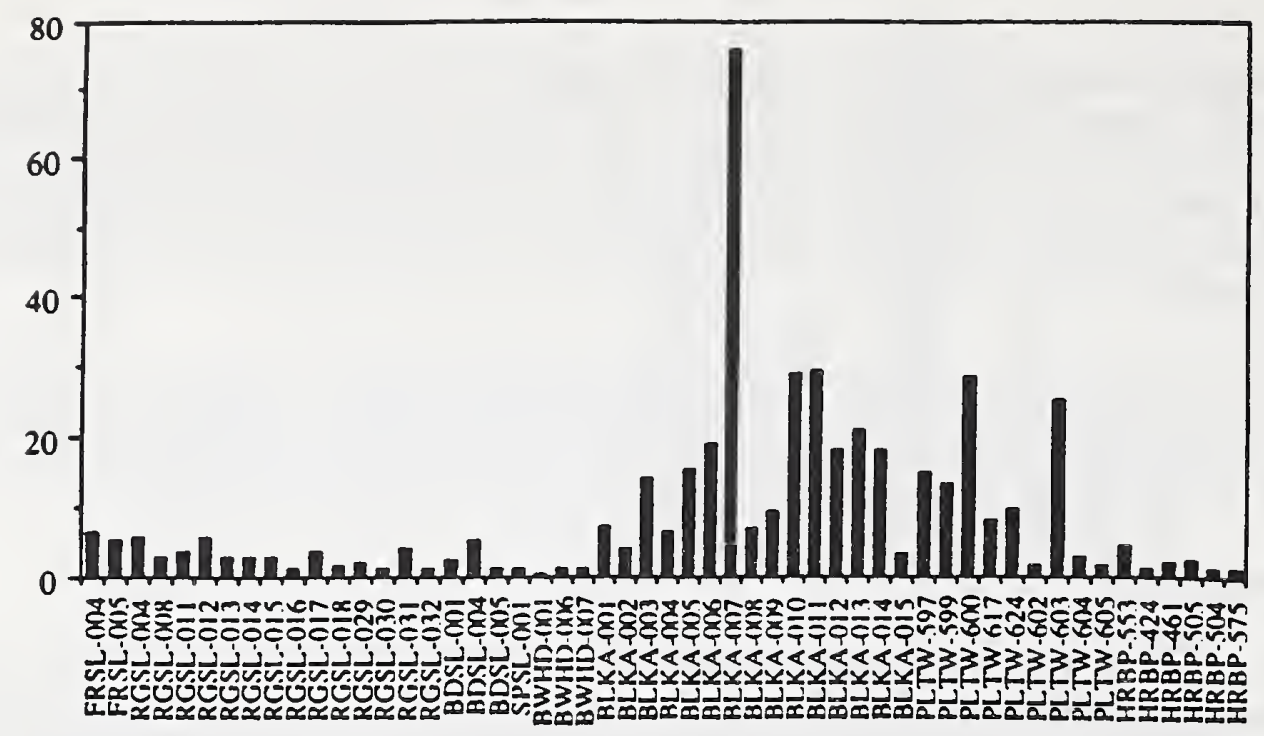

Figure 14. Selenium concentration ( $\mu \mathrm{g} / \mathrm{g}$ wet weight) in AMMTAP and NMMTB liver samples. AMMTAP animals: FRSL $=$ northern fur seal; $R G S L=$ ringed seal; $B D S L=$ bearded seal; SPSL $=$ spotted seal; $\mathrm{BWHD}=$ bowhead whale; $\mathrm{BLKA}=$ belukha whale. NMMTB animals: PLTW = pilot whale and HRBP = harbor porpoise.

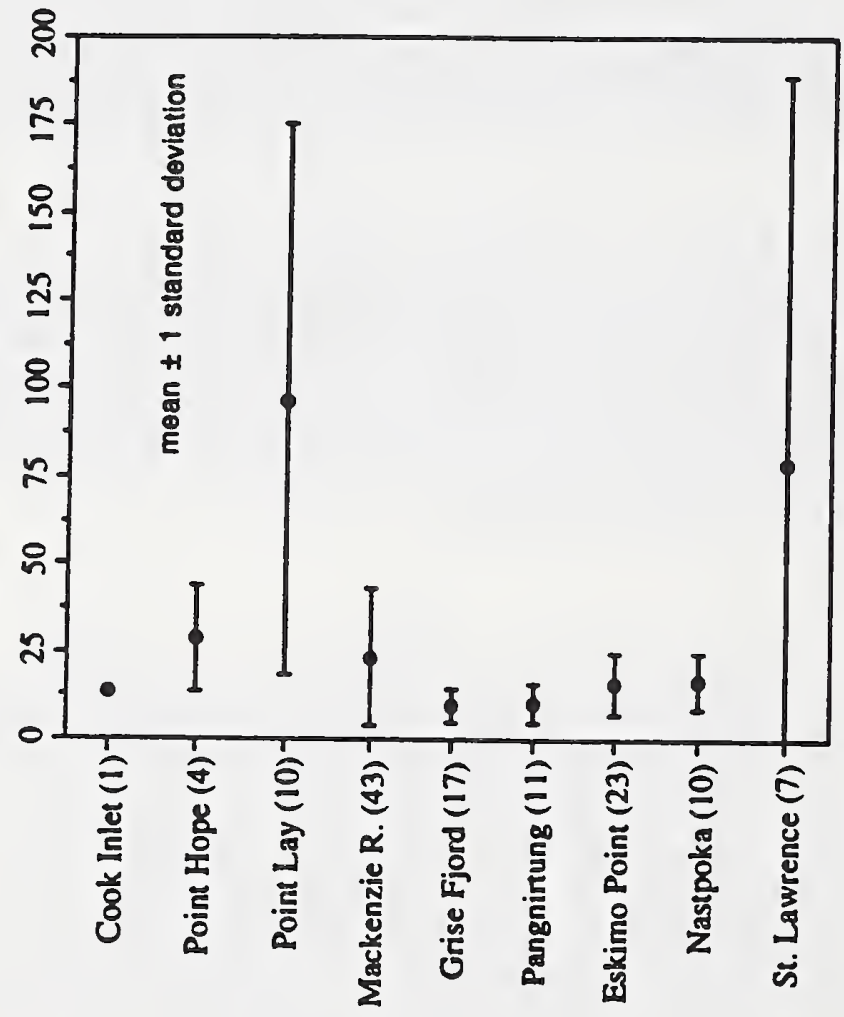

Figure 15. Comparison of selenium concentrations ( $\mu \mathrm{g} / \mathrm{g}$ dry weight) in liver of belukha whales from Alaska and Canada. Locations are presented from west to east (left to right); numbers of animals are in parentheses. Data for the six Canadian locations are from Wagemann et al. 1990. 


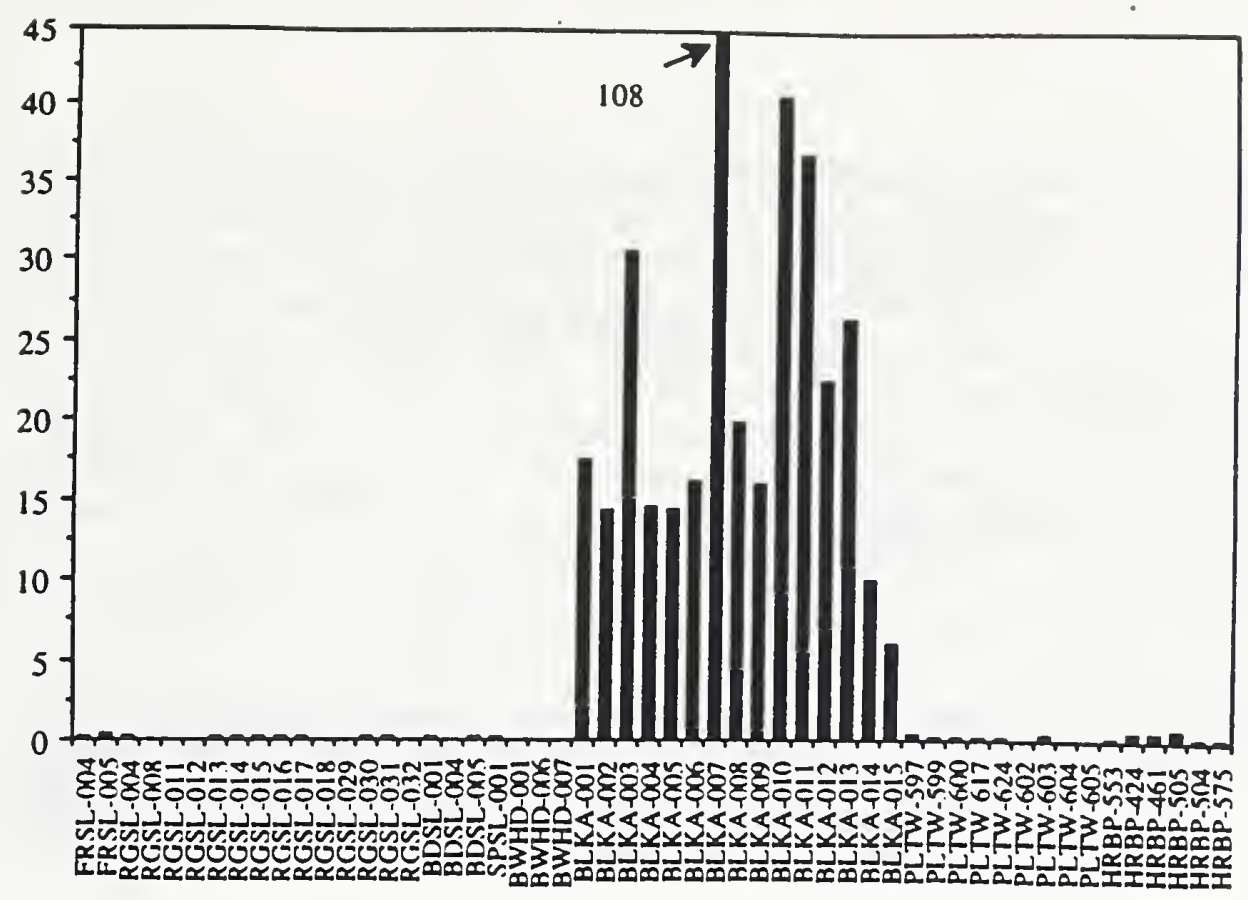

Figure 16. Silver concentration ( $\mu \mathrm{g} / \mathrm{g}$ wet weight) in AMMTAP and NMMTB liver samples. AMMTAP animals: FRSL $=$ northern fur seal; $R G S L=$ ringed seal; $B D S L=$ bearded seal; SPSL = spotted seal; $\mathrm{BWHD}=$ bowhead whale; $\mathrm{BLKA}=$ belukha whale. NMMTB animals: PLTW = pilot whale and $\mathrm{HRBP}=$ harbor porpoise.

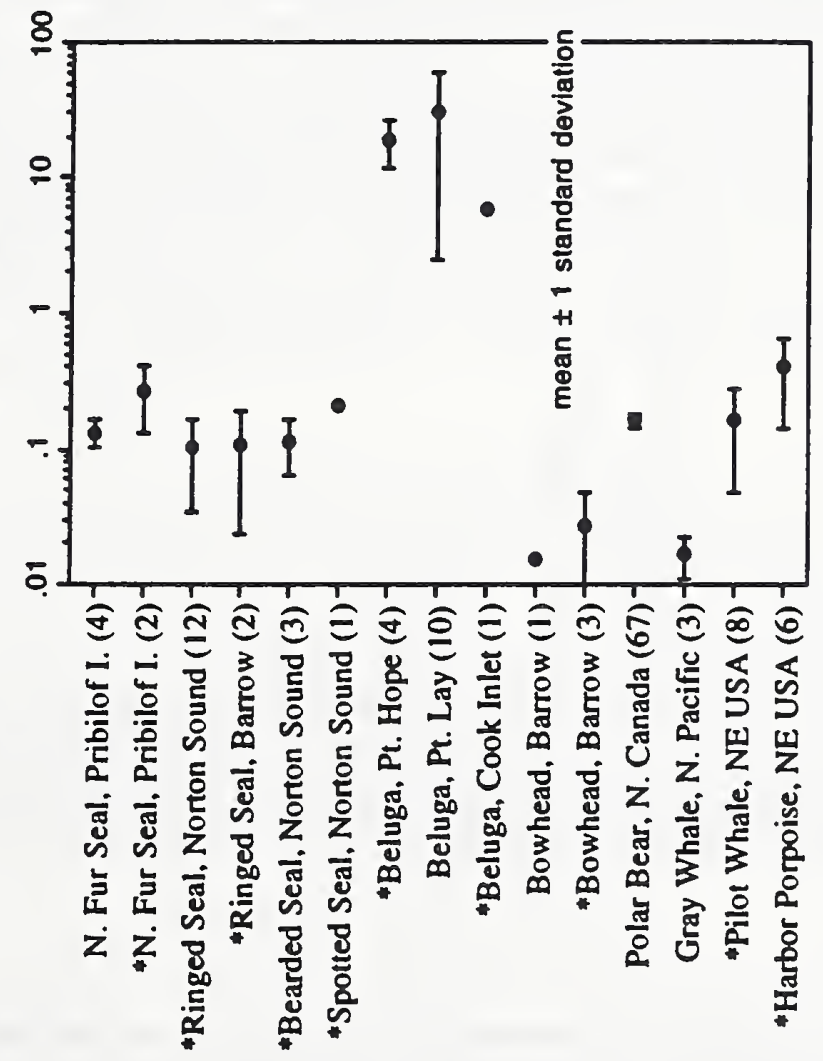

Figure 17. Comparison of silver concentrations ( $\mu \mathrm{g} / \mathrm{g}$ wet weight) in marine mammal liver tissue. AMMTAP and NMMTB data are indicated by an asterisk $(*)$. Other values are: fur seal from Smith (1986), bowhead from Byme et al. (1985), polar bear from Norstrom et al. (1986), and gray whale from Varanasi et al. (1993). Numbers of animals are in parentheses. 


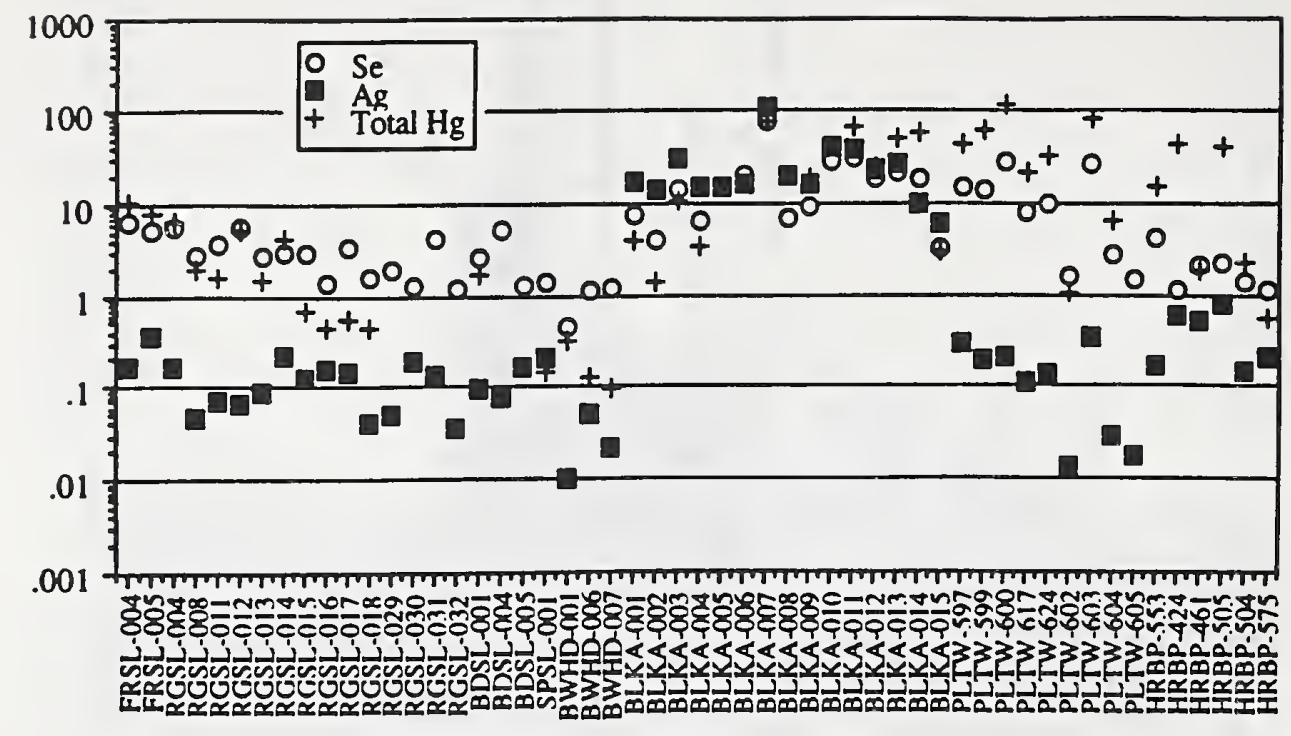

Figure 18. Comparison of the total mercury, selenium, and silver concentrations $(\mu \mathrm{g} / \mathrm{g}$ wet weight) in the liver tissue of animals sampled by AMMTAP and NMMTB.

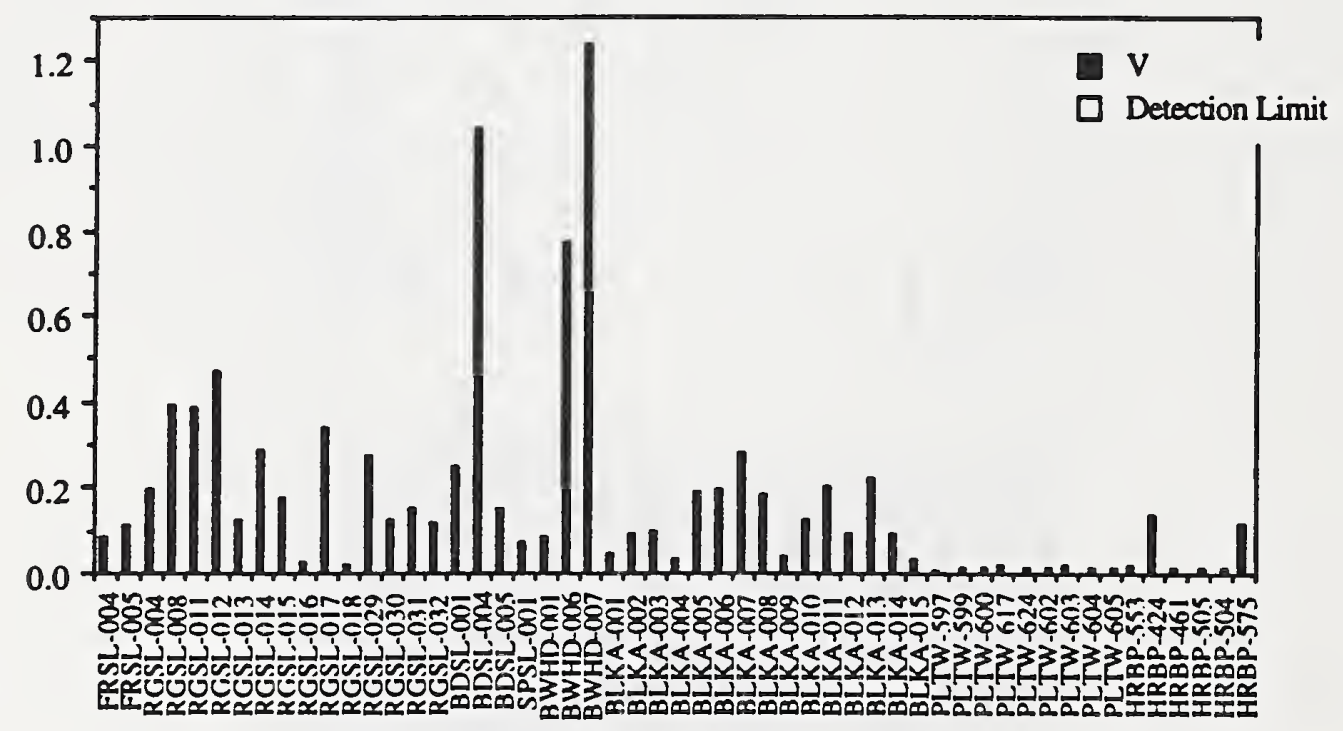

Figure 19. Vanadium concentration ( $\mu \mathrm{g} / \mathrm{g}$ wet weight) in AMMTAP and NMMTB liver samples. AMMTAP animals: FRSL $=$ northern fur seal; RGSL $=$ ringed seal; $B D S L=$ bearded seal; SPSL = spotted seal; $\mathrm{BWHD}=$ bowhead whale; $\mathrm{BLKA}=$ belukha whale. NMMTB animals: PLTW = pilot whale and $\mathrm{HRBP}=$ harbor porpoise . 
In all other cetaceans and pinnipeds from the AMMTAP and NMMTB, the levels of mercury and selenium are about the same order of magnitude and silver concentrations are substantially lower, but correlated with selenium to some degree. The linear correlation coefficient for hepatic silver versus hepatic selenium for pilot whales was 0.819 , significant at the $5 \%$ level, and for belukha whales 0.952 , significant at the $1 \%$ level. For the belukha whale livers, silver levels are comparable to those for selenium and mercury, and in some cases exceed the levels of these two elements (see Figure 18). The apparent correlation of silver with selenium does not necessarily indicate a direct relationship between the two elements but might be due to independent factors such as accumulation with age. However, physiological mechanisms involving the interaction of silver and selenium have been shown for other species of mammals and might also function in these marine mammals. These physiological mechanisms appear to be linked to the anti-oxidative functions of glutathione peroxidase and vitamin E (Ridlington and Whanger (1981). The interaction of silver with selenium differs from other selenium-metal interactions in mammals in that silver can induce symptoms of selenium deficiency in vitamin E-deficient animals by forming a silver-selenium complex that reduces the pool of available selenium used for normal cellular processes (Hammond and Beliles, 1980). The possible relationship between silver, mercury, and selenium in the belukha whale liver tissues from the AMMTAP has been discussed recently by Becker et al. (in press).

\section{Vanadium}

Vanadium concentrations in the liver of ringed seal, bowhead whales, and belukha whales varied widely (Figure 19). The highest values were found in two of the bowhead whales $(0.77$ and 1.23 $\mu \mathrm{g} / \mathrm{g}$ wet weight). The lowest concentration was found in the pilot whales, which had liver values as low as those reported for human liver tissue, e.g., $\leq 0.02 \mu \mathrm{g} / \mathrm{g}$ wet weight (Zeisler et al., 1983). Vanadium values were reported by Norstrom et al. (1986) for pooled liver samples from polar bears $(n=7)$ and by Warburton and Seagars (1993) for walrus $(n=53)$. The value reported by Norstrom et al. (1986) was $0.07 \mu \mathrm{g} / \mathrm{g}$ wet weight, which is in the low end of the range found in the AMMTAP belukha whale liver tissues. The values reported by Warburton and Seagars (1993) for walrus were higher than those found in the AMMTAP animals. Levels of vanadium in liver of walrus from the Bering and Chukchi seas ranged from 0.96 to $14.55 \mu \mathrm{g} / \mathrm{g}$ dry weight, with a mean of $6.04 \pm 3.12 \mathrm{SD}$. Converting the AMMTAP values to dry weight, the belukha whale liver concentrations of vanadium ranged from $0.122-1.119 \mu \mathrm{g} / \mathrm{g}$ and the bowhead liver concentrations ranged from $0.344-5.12 \mu \mathrm{g} / \mathrm{g}$.

Although the levels present in these tissues vary widely, vanadium is present at measurable levels in all of the Alaska marine mammal livers whereas for most of the east coast marine mammals, vanadium concentrations are at or below detection limits. Vanadium is used as an environmental indicator for the presence of crude oil. Although absolute vanadium concentrations vary for different oils, it is possible that the presence of vanadium in these whale liver tissues indicates the presence of oil in the Alaska marine environment.

\section{Zinc}

Like copper, zinc is an essential element regulated metabolically by vertebrates. Hepatic concentrations vary little between species, generally ranging from $20-60 \mu \mathrm{g} / \mathrm{g}$ wet weight (Thompson, 1990). Values for the AMMTAP and NMMTB animals are within this range (Figure 20). The range of hepatic zinc concentrations for the belukha whales was quite narrow (20-40 $\mu \mathrm{g} / \mathrm{g}$ ). A comparison with values reported by Wagemann et al. (1990) for belukha whales sampled from several locations in Canada shows that the range of hepatic zinc concentrations is very consistent for belukha whales throughout the Arctic and eastern Canada (Figure 21). Hepatic zinc concentrations for ringed seals are more variable. The liver of one seal, a relatively small male less than a year old (RGSL-016), from the Norton Sound, contained about $90 \mu \mathrm{g} / \mathrm{g}$ wet weight. Some of the highest zinc levels, far above the $20-60 \mu \mathrm{g} / \mathrm{g}$ range, were reported for pinnipeds from the 


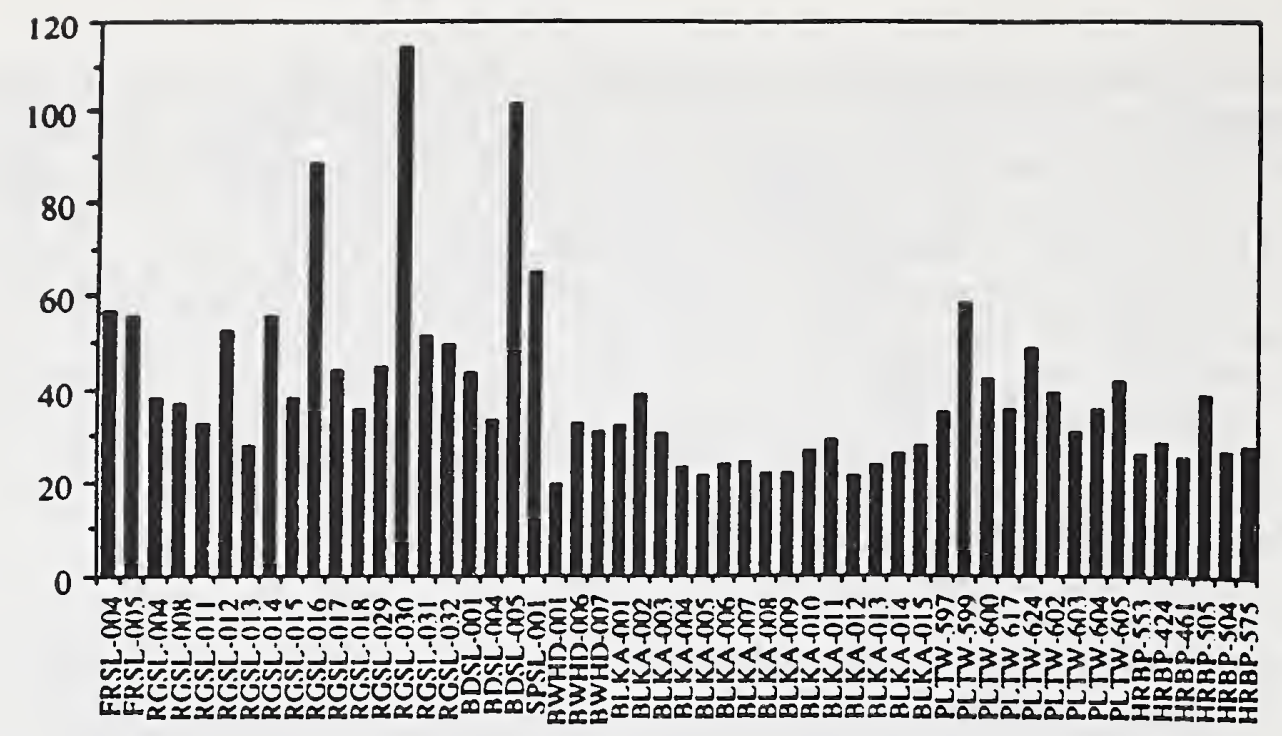

Figure 20. Zinc concentration $\mu g / g$ wet weight) in AMMTAP and NMMTB liver samples. AMMTAP animals: FRSL = northern fur seal; RGSL = ringed seal; $\mathrm{BDSL}=$ bearded seal; $\mathrm{SPSL}$ = spotted seal; $B W H D=$ bowhead whale; $B L K A=$ belukha whale. NMMTB animals: PLTW = pilot whale and HRBP = harbor porpoise.

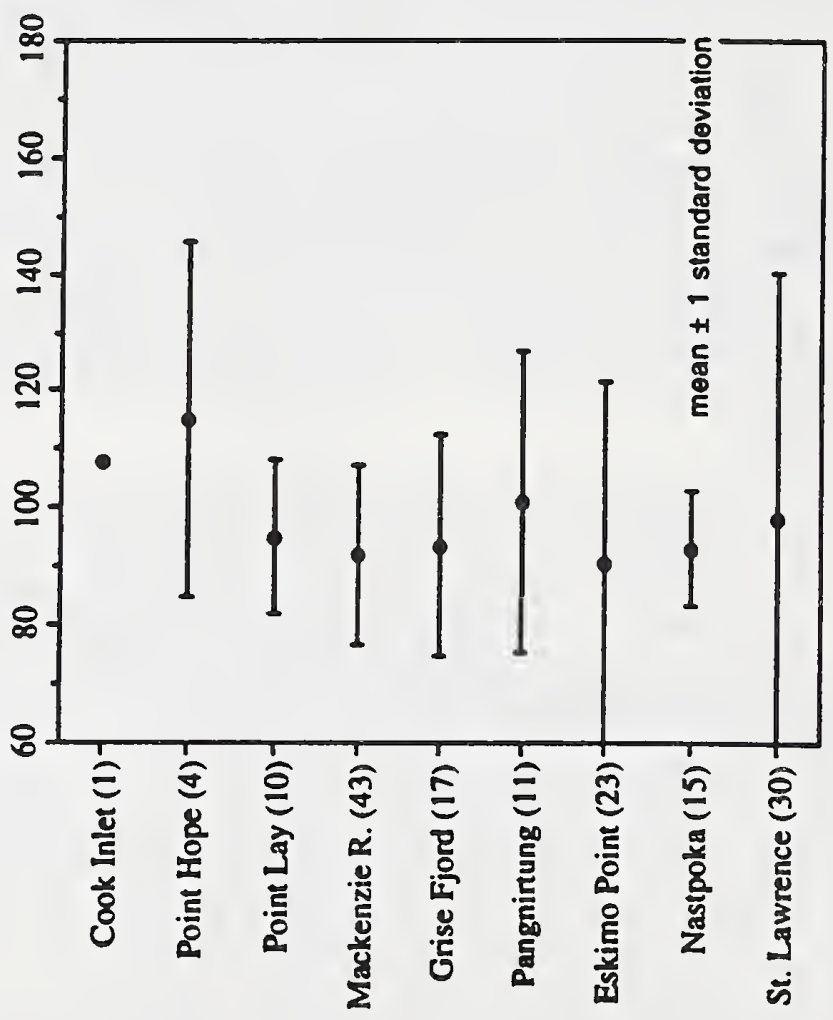

Figure 21. Comparison of zinc concentrations ( $\mu \mathrm{g} / \mathrm{g}$ dry weight) in liver of belukha whales from Alaska and Canada. Locations are presented from west to east (left to right); numbers of animals are in parentheses. Data for the six Canadian locations are from Wagemann et al. (1990). 
Antarctic. Thompson (1990) suggests that the higher hepatic zinc levels might reflect a natural dietary source that is high in zinc.

\section{Bioaccumulation}

For many trace elements in marine mammal tissues, little is known of baseline concentrations or what concentrations are within the normal range for a particular species. This information would be helpful in determining whether concentrations are increasing for a given population over time or whether bioaccumulation is occurring for a given species within a given organ. One measure of bioaccumulation is to determine whether concentrations increase with age. Concentrations in belukha whale liver were plotted versus age or length for each element. Positive correlations with age were observed for vanadium, selenium, silver, and mercury. These elements accumulate in liver tissue with age. The correlation between mercury and selenium and between selenium and silver may simply reflect that both elements accumulate with age or may also indicate a biochemical relationship between these elements. These biochemical relationships have been discussed in previous sections of this report as well as in Becker et al. (in press).

No correlation with age was observed for cadmium or for several other toxic elements. It is possible that some toxic elements do not accumulate in the same manner as others because of the existence of regulatory biochemical mechanisms that serve to prevent harmful bioaccumulation. For example, metallothioneins are known to protect mammalian bodies from the toxic effects of many trace elements, including cadmium and mercury. However, it still remains to be determined whether the concentration levels observed reflect levels that would be present naturally or whether the levels reflect the influence of anthropogenic inputs into the marine environment. Although most trace elements are acquired from diet rather than the surrounding water a comparison with levels present in seawater could indicate the presence of excessive amounts of a particular element in the marine environment. The relative amount of bioaccumulation was assessed by calculating enrichment factors, the amount of a given element present in the liver tissue relative to concentrations in sea water, normalized to sodium. Enrichment factor is defined in the following equation:

$$
\mathrm{EF}=[\mathrm{x}]_{1} /[\mathrm{Na}]_{1} / /[\mathrm{x}]_{\mathrm{S}} /[\mathrm{Na}]_{S}
$$

where $[x]_{1}$ is the concentration of element $x$ in the liver tissue and $[x]_{S}$ is the concentration of that same element in sea water (Drever, 1982). The enrichment factors for belukha whale liver tissue fall roughly into three categories: electrolytes, essential trace elements, and toxic (or potentially toxic) elements with the electrolytes showing the least enrichment and toxic trace elements the most (Figure 22). Cadmium and mercury fall into the last category and selenium is on the border between the last two categories. Similar trends are evident in the enrichment factors for ringed seal liver tissue. These results may indicate that bioaccumulation occurs for cadmium in liver tissue even without a linear correlation with animal age. 


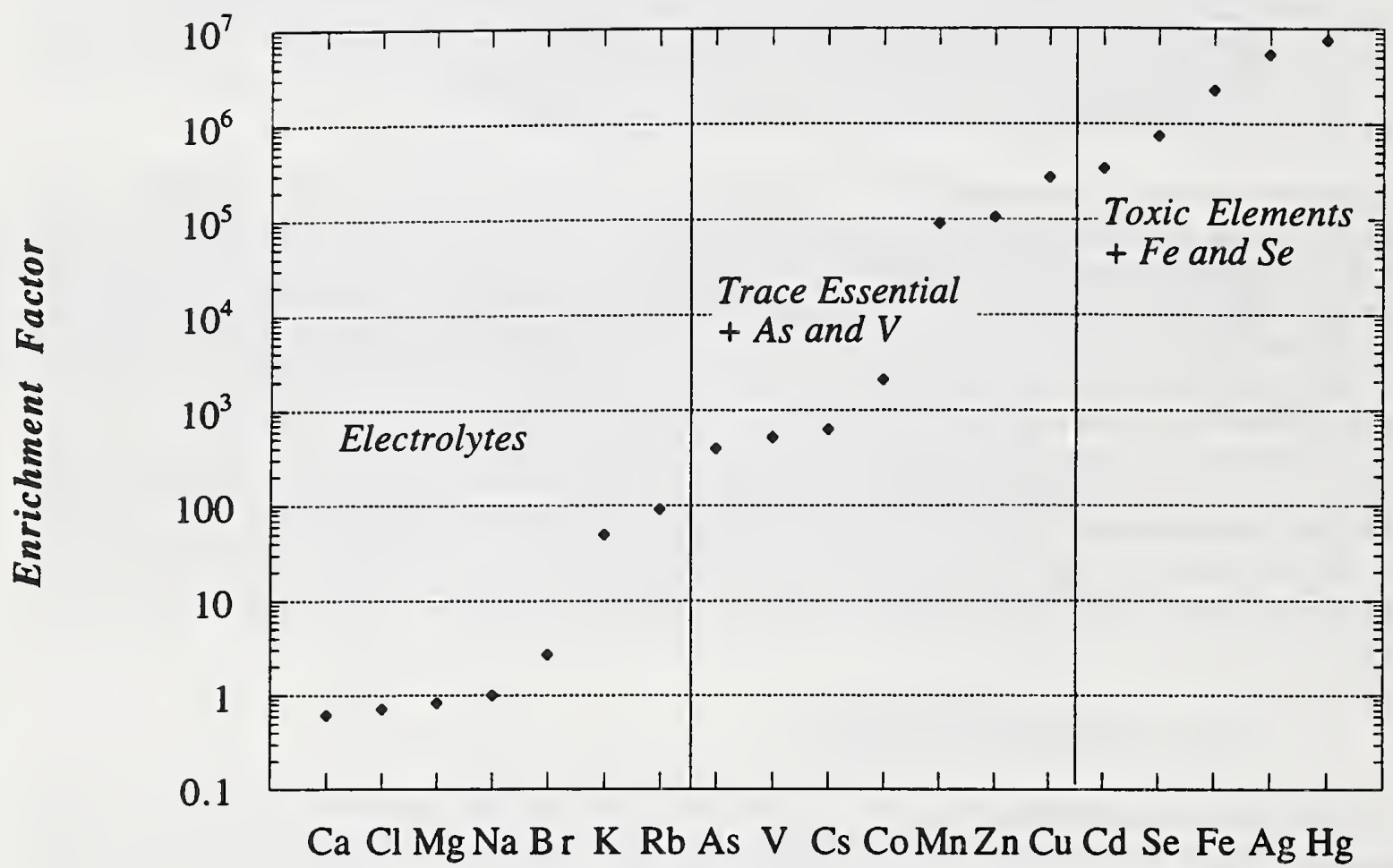

Element

Figure 22. Enrichment factors for belukha whale liver. 


\section{SUMMARY AND CONCLUSIONS}

It is very common to find PCBs and chlorinated pesticides such as DDT, $\mathrm{HCH}, \mathrm{HCB}$, dieldrin, mirex, chlordane, and toxaphene in Alaska marine mammals. Such contaminants are found throughout the world, including the most remote regions of the Arctic and Antarctic. Since these chemicals are lipophilic, the highest levels are found in the blubber. Of the species that the AMMTAP has sampled so far and for which chemical data are available, the highest levels of PCBs and chlorinated pesticides were found in the blubber of belukha whales sampled at Point Lay and Point Hope. Levels were somewhat higher in males than in the females, which is consistent with results reported for belukha whales from the Canadian Arctic, and closely resemble concentration levels reported for belukha whales sampled recently in Mackenzie Bay (eastern Beaufort Sea). The levels of PCBs are generally the same for the Arctic belukha whales as those for narwhal and polar bears, but an order of magnitude lower than levels for belukha whales from the St. Lawrence River Estuary, a population that is highly contaminated with organochlorine pesticides. The ratios of $4,4^{\prime}-\mathrm{DDE}$ to $\mathrm{EDDT}$ were quite similar for all belukha whales, including those from the St. Lawrence River Estuary.

Two groups of chlorinated pesticides that may be very important in the study of Arctic animals are the chlordanes and toxaphene. When one compares animals from lower latitudes with those from the northern latitudes and the Arctic, concentration levels of PCBs and most chlorinated pesticides generally decrease from south to north. However, in the case of chlordanes and toxaphene, there is much less difference between animals from the north and the south, and these two groups of chlorinated hydrocarbons contribute a relatively large fraction to the total amount of organochlorine compounds. The ratio of $\Sigma$ chlordane to $\Sigma$ PCBs, which reflects the relative contribution of chlordanes to the total organochlorines, appears to be much lower for belukha whales from the St. Lawrence River Estuary than for those from the Arctic.

The interpretation of heavy metal data in marine mammals is very difficult. Unlike PCBs and chlorinated pesticides, heavy metals occur naturally and levels can vary quite widely in the environment depending upon the regional geology. Alaska is highly mineralized with localized elevated levels of many heavy metals in rock and sediments. Cadmium and mercury are two heavy metals that are commonly present at high levels in marine mammal tissues (particularly in kidney and liver). Both elements are transferred to vertebrates through the food web and both may be present at relatively high levels in many kinds of seafood (shellfish, finfish, etc.). Both elements are non-essential; once taken up by a vertebrate, they are not easily eliminated and therefore bioaccumulate. One might expect that species from higher trophic levels would contain higher concentrations of cadmium and mercury. However, this is not always the case. Relatively high concentrations of mercury were found in the liver tissues of belukha whales sampled by the AMMTAP; however, cadmium concentrations for this species were very low. The bowhead whale, which feeds much lower in the food web than the belukha whale and which has very low levels of mercury, PCBs, and chlorinated hydrocarbons, had much higher hepatic cadmium concentrations. Cadmium in bowhead whale liver and kidney warrants further investigation, since the levels that we found and that have been previously reported by other investigators are quite high, approaching the levels found in northern fur seals from the Pribilof Islands and walrus from the Bering Sea.

The mercury concentrations in belukha whale livers were relatively high for the animals sampled at Point Lay (18 - 73 $\mu \mathrm{g} / \mathrm{g}$ wet weight) as compared with the levels in the liver tissue of the animals sampled at Point Hope $(1.4-10.2 \mu \mathrm{g} / \mathrm{g})$. The single whale from Cook Inlet, an older animal, had a relatively low concentration of mercury in its liver. Marine mammals accumulate mercury in a relatively non-toxic form. The toxic portion, methylmercury, is usually less than $2 \mu \mathrm{g} / \mathrm{g}$ wet weight liver. Although methylmercury was not determined in all of the belukha whale livers, for the specimens analyzed the values ranged from 0.36 to $2.15 \mu \mathrm{g} / \mathrm{g}$ wet weight. For the animals 
with the highest total mercury, methylmercury accounted for $3 \%$ of the total. The ability of some marine mammals to concentrate mercury to high levels in liver tissue is probably a protective mechanism by which the animals convert the toxic methyl form, which they ingest, into a nontoxic inorganic form which is then stored in the liver. Generally, hepatic selenium concentration is positively correlated with hepatic mercury. For many species, it has been shown that selenium combines with the mercury in liver to form a mercury selenide compound, a non-toxic form that is stored in the liver.

Arsenic levels in ringed seals from Norton Sound were quite high for marine mammals with six out of fourteen animals having levels over $1 \mu \mathrm{g} / \mathrm{g}$ wet weight. Although this might reflect a localized natural arsenic source (from the food web) for these animals, these arsenic levels are probably of no concern with regard to toxicity. Most seafoods have elevated arsenic levels and the liver tissue of the Norton Sound ringed seals had comparable levels of this trace element. The arsenic in marine biota are generally in an organic form, mostly arsenobetaine, which is essentially non-toxic and of no concern to humans consuming such biota. Bratton et al. (1993) measured organic arsenic in the liver tissue of one bowhead whale and found that approximately $98 \%$ of the total arsenic was in the form of arsenobetaine. Although we did not determine the form of arsenic, it is likely that most of it is in the organic form. However, until analyses for organic arsenic are performed, this can not be confirmed. The amount of arsenic in the liver tissues of the ringed seals does not pose a health risk for the seals or for the humans consuming these animals. However, the presence of these relatively high levels is of interest as this may represent an anomaly specific to the Norton Sound region and may be an example of a case in which a localized trace element source is reflected in a marine mammal species. The Norton Sound region is, historically, an important mining area and soil arsenic levels are normally elevated near arseniferous deposits and in mineralized zones containing gold, silver, and sulfides of lead and zinc (Dudas, 1984). 


\section{REFERENCES}

Addison, R. F., M. E. Zinck and T. G. Smith. 1986. PCB's have declined more than DDT-group residues in Arctic ringed seals (Phoca hispida) between 1972 and 1981. Environ. Sci. Technol. 20(3): 253-256.

AT, Am Test, Inc. 1988. Analysis Report To West Gold. 4 p.

Barrie, L. A., D. Gregor, B. Hargrave, R. Lake, D. Muir, R. Shearer, B. Tracey, and T. Bidlemen. 1992. Arctic contaminants: sources, occurrence and pathways. Sci. Total Environ. 122: $1-74$.

Becker, P. R., B. J. Koster, S. A. Wise, and R. Zeisler. 1990. Alaska Marine Mammal Tissue Archival Project. 1990. Biol. Trace Element Res. 26-27: 329-334.

Becker, P. R., E. A. Mackey, R. Demiralp, R. Suydam, G. Early, S. A. Wise, and B. J. Koster. Relationship of silver with selenium and mercury in the liver tissue of two species of toothed whales (Odontocetes). Mar. Poll, Bull., in press.

Becker, P. R., S. A. Wise, B. J. Koster, and R. Zeisler. 1991. Alaska Marine Mammal Tissue Archival Project: Revised Collection Protocol. NISTIR 4529. U.S. Department of Commerce, National Institute of Standards and Technology, Gaithersburg, MD. 39 p.

Becker, P. R., S. A. Wise, M. M. Schantz, B. J. Koster, and R. Zeisler. 1992. Alaska Marine Mammal Tissue Archival Project: Sample inventory and results of analyses of selected samples for organic compounds and trace elements. NISTIR 4731 U.S. Department of Commerce, National Institute of Standards and Technology, Gaithersburg, MD, $128 \mathrm{p}$.

Becker, P. R., S. A. Wise, and R. Zeisler. 1989. Alaskan Marine Mammal Tissue Archival Project: Acquisition and Curation of Alaskan Marine Mammal Tissues for Determining Levels of Contaminants Associated with Offshore Oil and Gas Development. Annual Report to U.S. Department of the Interior, Minerals Management Service, Anchorage, AK, 98 p.

Bratton, G. R., C. B. Spainhour, W. Flory, M. Reed, and J. Jayko. 1993. Presence and potential effects of contaminants. In: The Bowhead Whale, J. J. Burns, J. J. Montague and C. J. Cowles (eds), Special Publication Number 2, The Society for Marine Mammalogy. 701-744.

Brodie, P. F. 1969. Mandibular layering in Delphinapterus leucas and age determination. Nature 221: $956-958$.

Brodie, P. F. 1982. The belukha (Delphinapterus leucas): growth at age based on a captive specimen and a discussion of factors affecting natural mortality estimates. Reports of the International Whaling Commission 32: 445-447.

Burns, J. J. and G. A. Seaman. 1986. Investigations of belukha whales in coastal waters of western and northern Alaska. II. Biology and ecology. Final Report NOAA Outer Continental Shelf Environmental Assessment Program Contract NA-81-RAC-00049. Alaska Department of Fish and Game, Fairbanks, AK. 129 p.

Byrne, C., R. Balasuramanian, E. B. Overton, and T. F. Albert. 1985. Concentrations of trace metals in the bowhead whale. Mar. Poll. Bull. 16: 497-498. 
Calambokidis, J., and J. Peard. 1985. Chlorinated hydrocarbons in tissue of northern fur seals from St. Paul Island, Alaska. Final Report. Fur Seal Investigations, 1982. Pat Kozoloff (ed.) NOAA Tech. Memo. NMFS F/NWC-71. NMM Lab, Seattle, WA. 75-79.

Dearth, M. A., and R. A. Hites. Complete analysis of technical chlordane using negative ion mass spectrometry. 1991. Environ. Sci. Technol. 25: 245-254.

Dewailly, E., P. Ayotte, S. Bruneau, C. Laliberte, D. C. G. Muir, and R. J. Norstrom. 1993. Inuit exposure to organochlorines through the aquatic food chain in Arctic Quebec. Environ. Health Perspect. 101(7): 618-620.

Dietz, R., C. O. Nielsen, M. M. Hansen, and C. T. Hansen. 1990. Organic mercury in Greenland birds and mammals. Sci. Total Environ. 95: 41-51.

Drever, J. I. 1982. The Geochemistry of Natural Waters, Prentice-Hall, Inc., Englewood Cliffs, N.J. 234.

Dudas, M. J. 1984. Enriched levels of arsenic in pot-active acid sulfate soils in Alberta. Soil Sci. Soc. Am. J. 48: 1451-1452.

Edmonds, J. S., and K. A. Francesconi. 1993. Arsenic in seafoods: human health aspects and regulations. Marine Poll. Bull. 26(12): 665-674.

Eisler, R. 1988. Arsenic Hazards to Fish, Wildlife, and Invertebrates: A Synoptic Review. Biological Report 85(1.12), Contaminant Hazard Reviews, Report No. 12. U.S. Department of Interior, Fish and Wildlife Service. $92 \mathrm{p}$.

Eisler, R. 1981. Trace Metal Concentrations in Marine Organisms. Pergamon Press, New York. $687 \mathrm{p}$.

Ernst, W., R. G. Schaefer, H. Goerke, and G. Eder. 1974. Aufarbeitung von meerestieren für die bestimmung von PCB, DDT, DDE, DDD, $\gamma-\mathrm{HCH}$ und HCB. Fresenius $Z$. Anal. Chem. 272: 358-363.

Falconer, C. R., I. M. Davies and G. Topping. 1983. Trace metals in the common porpoise, Phocoena phocoena.. Mar. Environ. Res. 8: 119-127.

Fowler, S. W., and M. Y. Unlu. 1978. Factors affecting bioaccumulation and elimination of arsenic in the shrimp, Lysmata seticaudata.. Chemosphere 9:711-720.

GESAMP. 1986. (IMO/FAO/UNESCO/WMO/WHO/IAEA/UN/UNEP Joint group of experts on the scientific aspects of marine pollution). Review of potentially harmful substances: arsenic, mercury and selenium. Reports and Studies GESAMP (28).

Goren, A. D., P. F. Brodie, S. Spotte, G. C. Ray, H. W. Kaufman, A. J. Gwinnett, J. J. Sciubba, and J. D. Buck. 1987. Growth layer groups (GLGs) in the teeth of the adult belukha whale (Delphinapterus leucas) of known age: evidence for two annual layers. Mar. Mam. Sci. 3: 14-21.

Hall, R. A., E. G. Zook, and G. M. Meaburn. 1978. National Marine Fisheries Service survey of trace elements in the fishery resources. U.S. Dep. Commerce NOAA Tech. Rep. NMFS SSRF$721,313 \mathrm{p}$. 
Hammond, P. B. and R. P. Beliles. 1980. Metals. In: Casareet and Doull's Toxicology: the Basic Science of Poisons, Second Edition (J. Doull, C. D. Klaassen and M. O. Amdur, eds). Macmillan Publishing Co., Inc., New York, NY, pp. 409-467.

Hansen, C. T., C. O. Nielsen, R. Dietz, and M. M. Hansen, 1990. Zinc, cadmium, mercury and selenium in minke whales, belukhas and narwhals from West Greenland. Polar Biol. 10: 529539.

Hazard, K. 1988. Belukha whale. In: Selected Marine Mammals of Alaska: Species Accounts with research and Management Recommendations. J. W. Lentfer, ed. Marine Mammal Commission, Washington, DC, pp. 409-467.

Honda, K., R. Tatsukawa, K. Itano, N. Miyazaki, and T. Fujiyama. 1983. Heavy metal concentrations in muscle, liver and kidney tissue of striped dolphin, Stenella coeruleoalba, and their variations with body length, weight, age and sex. Agric. Biol. Chem. 47: 1219-1228.

Jenkins, D. W. 1980. Biological monitoring of toxic trace metals. Vol. 2. Toxic trace metals in plants and animals of the world. Part I. U.S. Environ. Protection Agency Rep. 600/3-80-090: 30-138.

Jongen, W. M. F., J. M. Cardinaals, and P. M. J. Box. 1985. Genotoxicity testing of arsenobetaine, the predominant form of arsenic in marine fishery products. Food Chem. Toxicol. 23: 669-673.

Kaise, T., S. Watanabe, and K. Itoh. 1985. The acute toxicity of arsenobetaine. Chemosphere 14: 1327-1332.

Kinloch, D., H. Kuhnlein, and D. C. G. Muir. 1992. Inuit foods and diet: a preliminary assessment of benefits and risks. Sci. Total Environ. 122: 247-278.

Koster, B. J., S. A. Wise, and P. R. Becker, Alaska Marine Mammal Tissue Archival Project: Specimen Inventory, NISTIR-5462, 1994.

Kurtz, D. A. 1987. PCB/DDT contamination in northern fur seals. Report to the National Geographic Society, Committee for Research and Exploration. June 23, 1987. 18 p.

Maher, W.A. 1985. The presence of arsenobetaine in marine animals. Comp. Biochem. Physiol. 80C: $199-201$.

Martoja, R., and D. Viale. 1977. Accumulation de granules de séléniure mercurique dans le foie d'Odontocétes (Mammiféres Cétacés): un mécanisme possible de détoxification du méthylmercure par le sélénium. C. R. Acad. Sci. 285: 109-112.

May, K., and M. Stoeppler. 1984. Pretreatment Studies with Biological and Environmental Materials. IV. Complete wet digestion in partly and completely closed quartz vessels for subsequent trace and ultratrace mercury determination. Fresenius Z. Anal. Chem. 317: 248-251.

McClurg, T. P. 1984. Trace metals and chlorinated hydrocarbons in Ross seals from Antarctica. Mar. Poll. Bull. 15(10): 384-389.

Meador, J. P. Varanasi, P. A. Robisch, and S-L. Chan, Toxic Metals in Pilot Whales (Globicephala melaena) from strandings in 1986 and 1990 on Cape Cod, MA., Canadian J. Fish. Aquatic Sci., 50: 2698-2706. 
Muir, D. C. G., C. A. Ford, N. P. Grift, R. E. A. Stewart, and T. F. Bidleman. 1992 a. Organochlorine contaminants in narwhal (Monodon monoceros) from the Canadian Arctic. Environ. Pollut. 75: 307-316.

Muir, D. C. G, C. A. Ford, R. E. A. Stewart, T. G. Smith, R. F. Addison, M. E. Zinck, and P. Béland. 1990. Organochlorine contaminants in belukhas, Delphinapterus leucas, from Canadian waters. Can. Bull. Fish. Aquat. Sci. 224: 165-190.

Muir, D. C. G., R. J. Norstrom, and M. Simon. 1988a. Organochlorine contaminants in arctic marine food chains: accumulation of specific polychlorinated biphenyls and chlordane-related compounds. Environ. Sci. Technol. 22: 1071-1079.

Muir, D. C. G., R. Wagemann, N. P. Grift, R. J. Norstrom, M. Simon, and J. Lein. 1988 b. Organochlorine chemical and heavy metal contaminants in white-beaked dolphins (Lagenorhynchus albirostris) and pilot whales (Globicephala melaena) from the coast of Newfoundland, Canada. Arch. Environ. Toxicol. Chem. 17: 613-629.

Muir, D. C. G., R. Wagemann, B. T. Hargrave, D. J. Thomas, D. B. Peakall, and R. J. Norstrom. 1992b. Arctic marine ecosystem contamination. Sci. Total Environ. 122(1/2): 74134.

Norheim, G. 1987. Levels and interactions of heavy metals in sea birds from Svalbard and the Antarctic. Environ. Pollut. 47: 83-94.

Norstrom, R. J., R. E. Schweinsberg, and B. T. Collins. 1986. Heavy metals and essential elements in livers of the polar bear (Ursus maritimus) in the Canadian Arctic. Sci. Total Environ. 48: $195-212$.

Norstrom, R. J., M. Simon, D. C. G. Muir, and R. E. Schwinsberg. 1988. Organochlorine contaminants in arctic marine food chains: identification, geographical distribution and temporal trends in polar bears. Environ. Sci. Technol. 22: 1063-1071.

Norstrom, R. J., and H. T. Won. 1985. Long-term preservation of eggs and tissue homogenates for determination of organochlorine compounds: freezing versus freeze-drying. J. Assoc. Off. Anal. Chem. 68: 130-135.

Oehme, M., P. Fürst, C. Krüger, H. A. Meemken, and W. Groebel. 1988. Presence of polychlorinated dibenzofurans and pesticides in Arctic seal from Spitsbergen (Norway). Chemosphere 17(7): 1291-1300.

Ostapczuk, P., P. Valenta, and H. W. Nurnberg. 1986. Square wave voltammetry-- A rapid and reliable determination method of $\mathrm{Zn}, \mathrm{Cd}, \mathrm{Pb}, \mathrm{Cu}, \mathrm{Ni}$ and $\mathrm{Co}$ in biological and environmental samples. J. Electroanal. Chem. 214: 51-64.

Ridlington, J. W., and P. D. Whanger. 1981. Interactions of selenium and antioxidants with mercury, cadmium and silver. Fundam. Appl. Toxicol. 1: 368-375.

Rotruck, J. T. 1973. Selenium: biochemical role as a component of glutathione peroxidase. Science 179: 588-590.

Schantz, M. M., B. J. Koster, R. Zeisler, S. A. Wise, and P. R. Becker. 1993. Determination of PCBs and chlorinated hydrocarbons in marine mammal tissues. Sci. Total Environ. 139/140: 323-345. 
Sergeant, D. E. 1959. Age determination in Odontocete whales from dentinal growth layers. Norsk Hvalfangst-tidende 48: 273-288.

Smith, D. R. 1986. Trace Metal Concentrations in Northern Fur Seals (Callorhinus ursinus) from the Pribilof Islands. Report to NMFS. Creative Educational Consultants, Monterey, CA, USA. 5 p.

Soto., E. G., D. P. Rodriguez, E. A. Rodriguez, P. L. Mahia, E. Fernandez, and A. C. Zubieta. 1993. Inorganic As(III) and As(V) quantification in marine organisms. Mar. Poll. Bull. 26(6): 335-338.

Stern, G. A., D. C. G. Muir, M. D. Segstro, R. Dietz, and M. P. Heide-Jørgensen. 1994. PCB's and other organochlorine contaminants in white whales (Delphinapterus leucas) from West Greenland: Variations with age and sex. Medd. om Grønland, Bioscience 39: 243-257.

Taylor, D. L., S. Schliebe, and H. Metsker. 1989. Contaminants in blubber, liver and kidney tissue of Pacific walruses. Mar. Pollut. Bull. 20: 465-468.

Thompson, D. R. 1990. Metal levels in marine vertebrates. In: Heavy Metals in the Marine Environment. R. W. Furness and P. S. Rainbow (eds.) CRC Press, Inc. Boca Raton, FL. 143182.

Thomas, D. J., and M. C. Hamilton. 1988. Organochlorine residues in biota of the Baffin Island region, SEAKEM Oceanography, Ltd., Sidney, BC. Indian and Northern Affairs Canada, Ottawa.

Vahter, M., and J. Envall. 1983. In vivo reduction of arsenate in mice and rabbits. Environ. Res. 32: 14-24.

Wagemann, R. 1993. Lead and other heavy metals in tissues of walrus and ringed seals. In: Synopsis of Research Conducted Under the 1992/93 Northern Contaminants Program, L. J. Murray, and R. G. Shearer, (eds.). Environmental Studies No. 70: 105-116.

Wagemann, R., N. B. Snow, A. Lutz, and D. P. Scott. 1983. Heavy metals in tissues and organs of the narwhal (Monodon monoceros). Can. J. Fish. Aquat. Sci. 40(Suppl. 2): 206-214.

Wagemann, R., R. E. A. Stewart, P. Béland, and C. Desjardins. 1990. Heavy metals and selenium in tissues of belukha whales, Delphinapterus leucas, from the Canadian Arctic and the St. Lawrence Estuary. Can. Bull. Fish. Aquat. Sci. 224: 191-206.

Warburton, J., and Seagars, D. J. 1993. Heavy metal concentrations in liver and kidney tissues of Pacific walrus: Continuation of a baseline study. USFWS Technical Report R7/MMM 93-1. Anchorage, Alaska.

Wise, S. A., B. J. Koster, J. K. Langland, and R. Zeisler, 1994. Current Activities within the National Biomonitoring Specimen Bank. Sci. Total Environ. 139/140: 1 - 12.

Wise, S. A. 1993. Quality assurance of contaminant measurements in marine mammal tissues. Coastal Zone 93: Proceedings of the 8th Symposium on Coastal and Ocean Management (New Orleans, LA), O. T. Magoon, W. S. Wilson, H. Converse, and L. T. Tobin, eds. ASCE, New York, NY. 3: 22531-2541. 
Wise, S. A., M. M. Schantz, B. J. Koster, R. Demiralp, E. A. Mackey, R. R. Greenberg, M. Burow, P. Ostapczuk, and T. I. Lillestolen. 1993. Development of frozen whale blubber and liver reference materials for the measurement of organic and inorganic contaminants. Fresenius $J$. Anal. Chem. 345: 270-277.

Wise, S. A., B. J. Koster, R. M. Parris, M. M. Schantz, S. R. Stone, and R. Zeisler. 1989. Experiences in environmental specimen banking. Intern. J. Environ. Anal. Chem. 37: 91-106.

Wise, S. A., and R. Zeisler. 1984. The pilot Environmental Specimen Bank program. Environ. Sci. Technol. 18(10): 302A-307A.

Wrench, J. S., W. Fowler, and M. Y. Ünlü. 1979. Arsenic metabolism in a marine food chain. Mar. Poll. Bull. 10(1): 18-20.

Würfels, M., E. Jackwerth, and M. Stoeppler. 1989. Residues from biological materials after pressure decomposition with nitric acid. Part 1. Carbon conversion during sample decomposition. Analytica Chimica Acta. 226: 1-16.

Zeisler, R., R. Demiralp, B. J. Koster, P. R. Becker, M. Burow, P. Ostapczuk, and S. A. Wise. 1993. Determination of inorganic constituents in marine mammal tissues. Sci. Total Environ. 139/140: 365-386.

Zeisler, R., S. H. Harrison, and S. A. Wise, eds. 1983. The Pilot National Environmental Specimen Bank- Analysis of Human Liver Specimens. National Bureau of Standards Special Publication 656. Gaithersburg, MD. 135 p. 
APPENDIX A

CHLORINATED HYDROCARBON DATA: BELUKHA WHALE BLUBBER 
A list of the abbreviations used in Appendices $A$ and $B$ are shown below in Table A-1. NA indicates that there was no analysis; ND indicates that the substance was not detected, e.g., below minimum detection limit (MDL). Chlordane related compounds, "C", C1A, C2/U5, C3, C5, U3, are U1 are defined according to Dearth and Hites, 1991. Concentration values are expressed as ng. $\mathrm{g}^{-1}$, wet weight (ppb, wet weight).

Table A-1. List of abbreviations.

TCB = tetrachlorobenzene

$\mathrm{P5CBZ}=$ pentachlorobenzene

HCBZ - hexachlorobenzene

$\Sigma \mathrm{CBZ}=$ sum of chlorobenzenes

$\mathrm{HCH}=$ hexachlorocyclohexane

$\alpha-\mathrm{HCH}=$ alpha hexachlorocyclohexane

$\beta-\mathrm{HCH}=$ beta hexachlorocyclohexane

$\gamma-\mathrm{HCH}=$ gamma hexachlorocyclohexane

"C"= chlordane "C"

HCHLOR = heptachlor

OCSTYR = octachlorostyrene

$\mathrm{C} 1 \mathrm{~A}=$ chlordane-C $1 \mathrm{~A}$

$\mathrm{C} 2 / \mathrm{U}-5=$ chlordane-C2/U5

$\mathrm{C} 3$ = chlordane-C3

$\mathrm{C} 5=$ chlordane-C5

U3 = nonachlor III

$\mathrm{U} 1=$ cphotoheptachlor

$\mathrm{U} 1=$ cphotoheptachlor
OXYCLR = oxychlordane

$\mathrm{T}-\mathrm{CHLOR}=$ trans-chlordane

$\mathrm{C}-\mathrm{CHLOR}=$ cis-chlordane

T-NONA = trans-nonachlor

C-NONA = cis-nonachlor

H.EPOX = heptachlor epoxide

$\Sigma C H L O R=$ sum of chlordane compounds

$\Sigma T O X=$ sum of chlorobornane congeners $\Sigma$ TOXSRF = Toxaphene; single response factor calculation

MONO/DI = mono- and dichlorobiphenyl

TETRA = tetrachlorobiphenyls

PENTA = pentachlorobiphenyls

HEXA = hexachlorobiphenyls

HEPTA = heptachlorobiphenyls

OCTA = octachlorobiphenyls

NONA = nonachlorobiphenyls

$\mathrm{DECA}=$ decachlorobiphenyls 


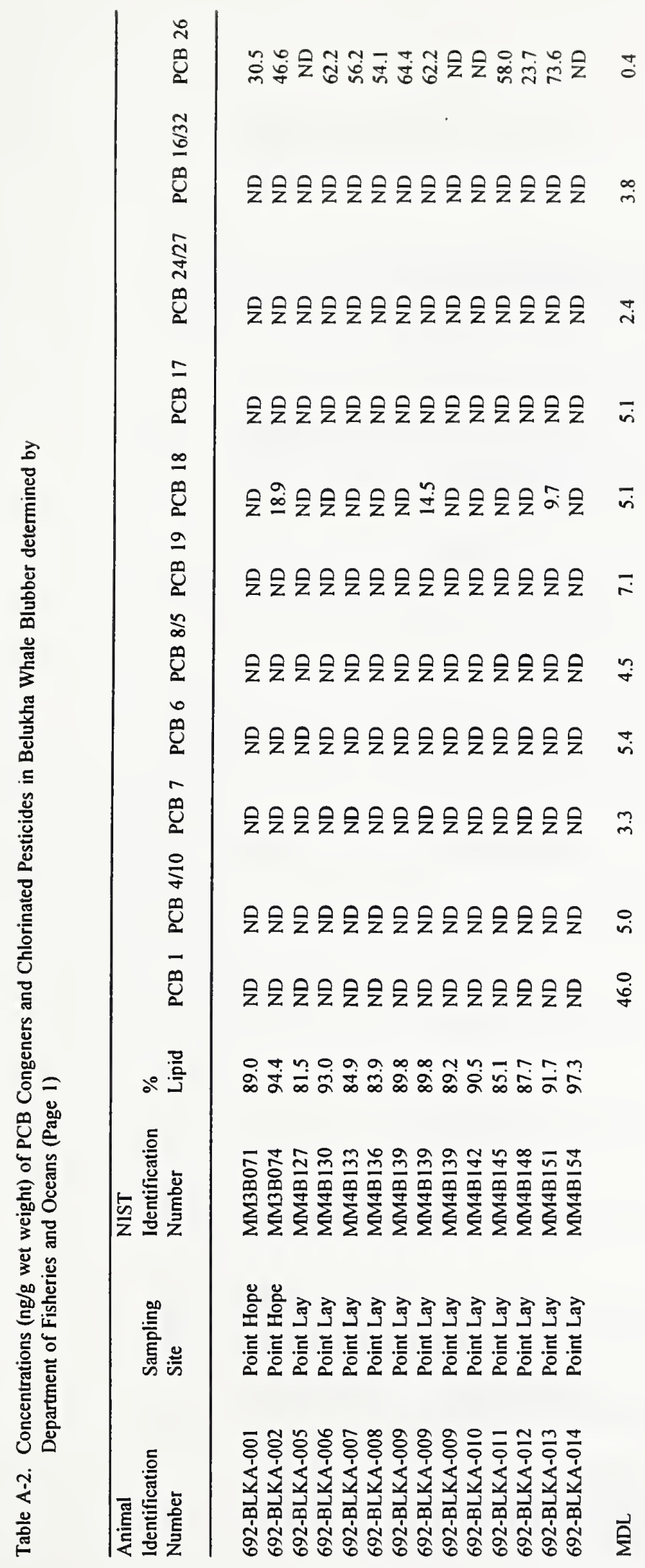




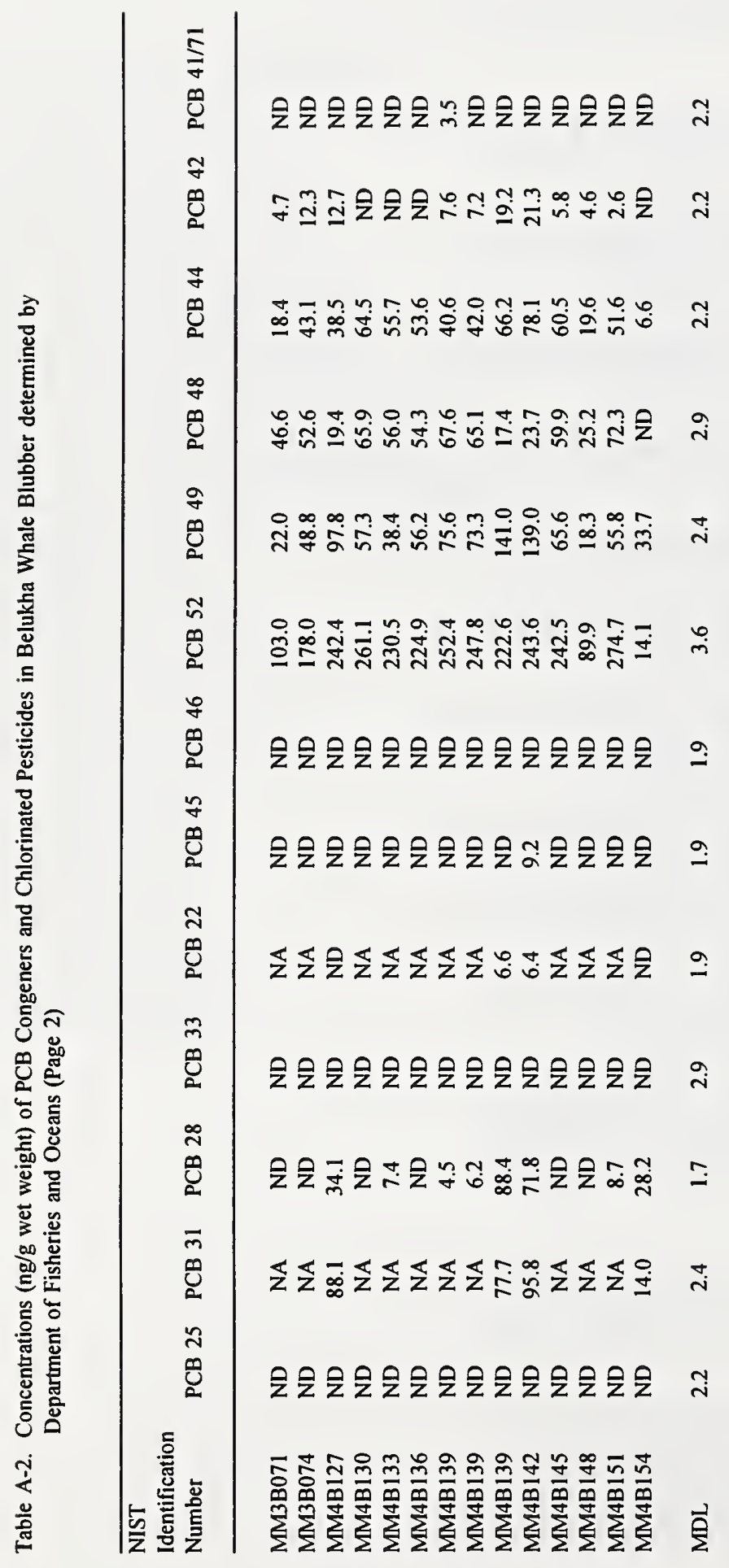




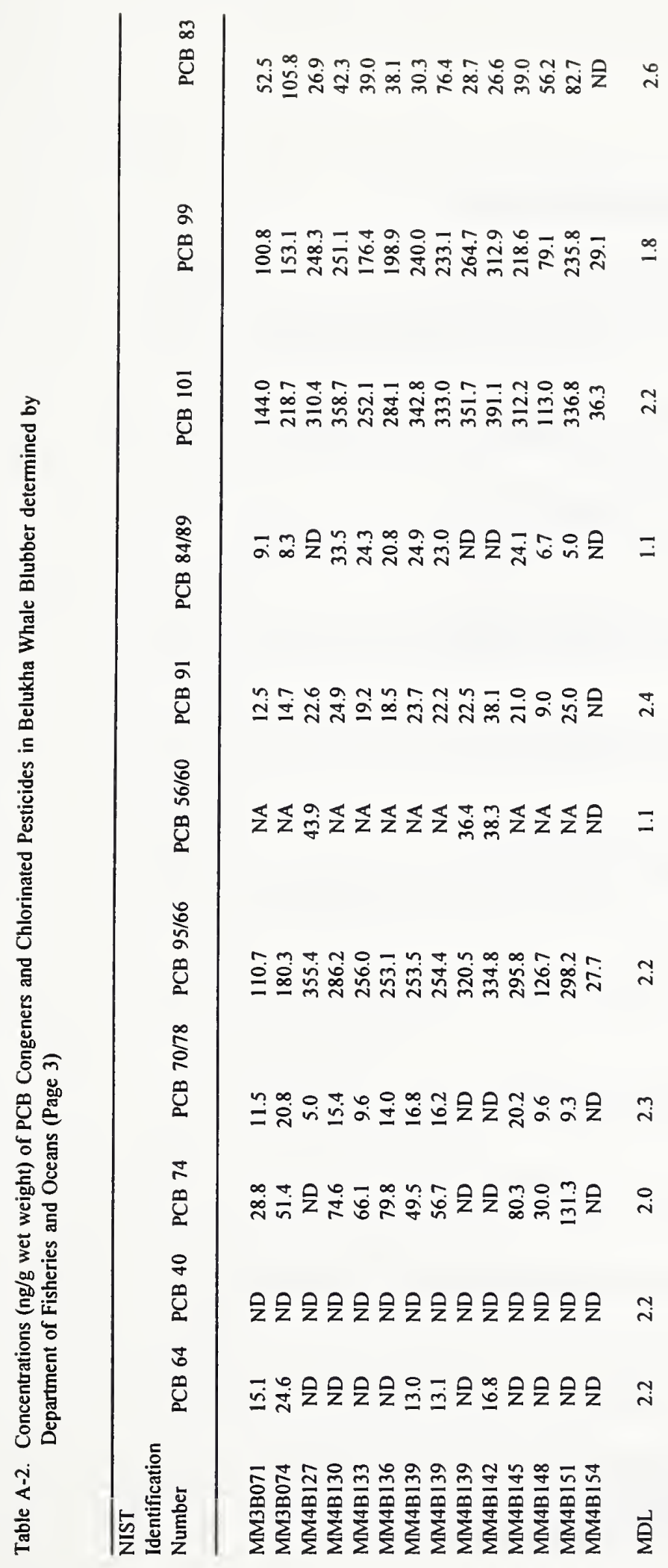




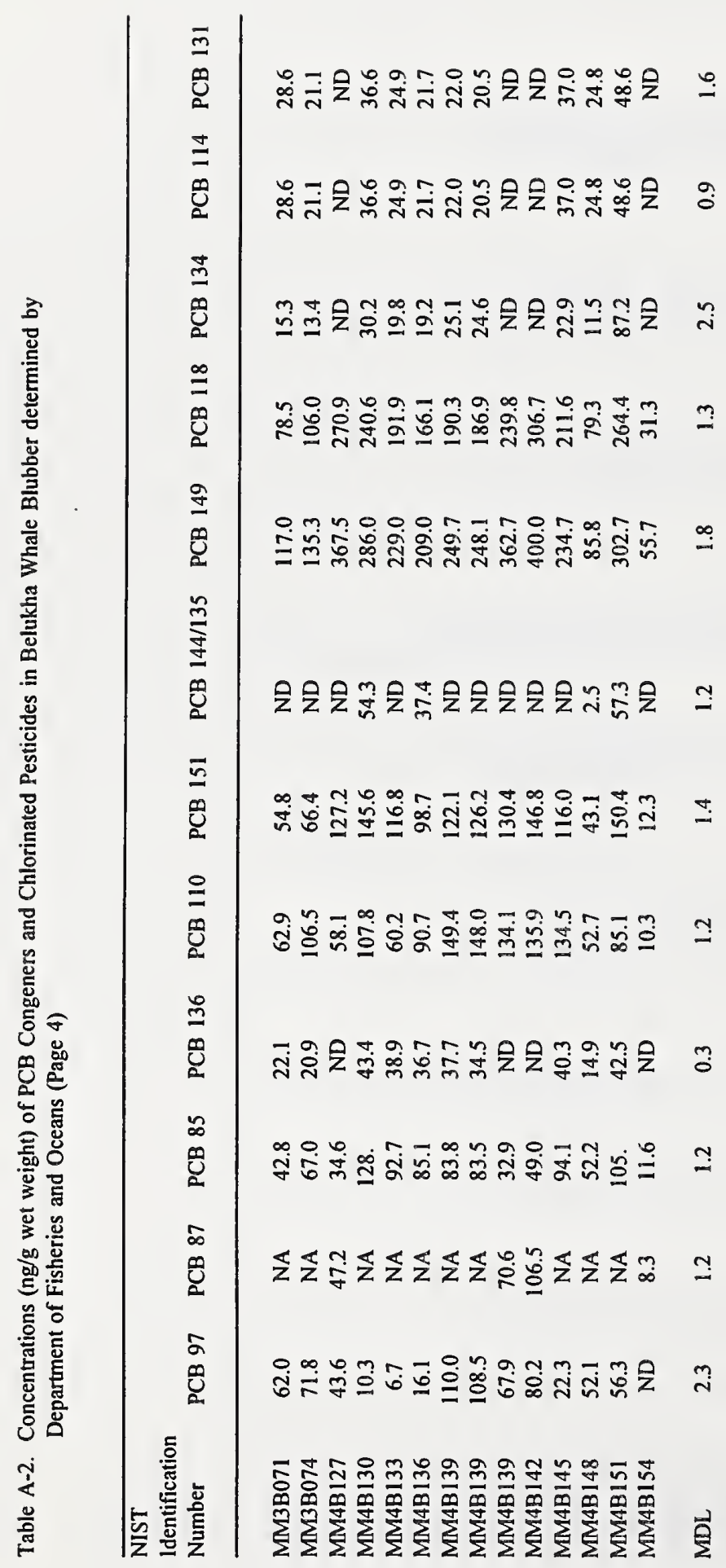




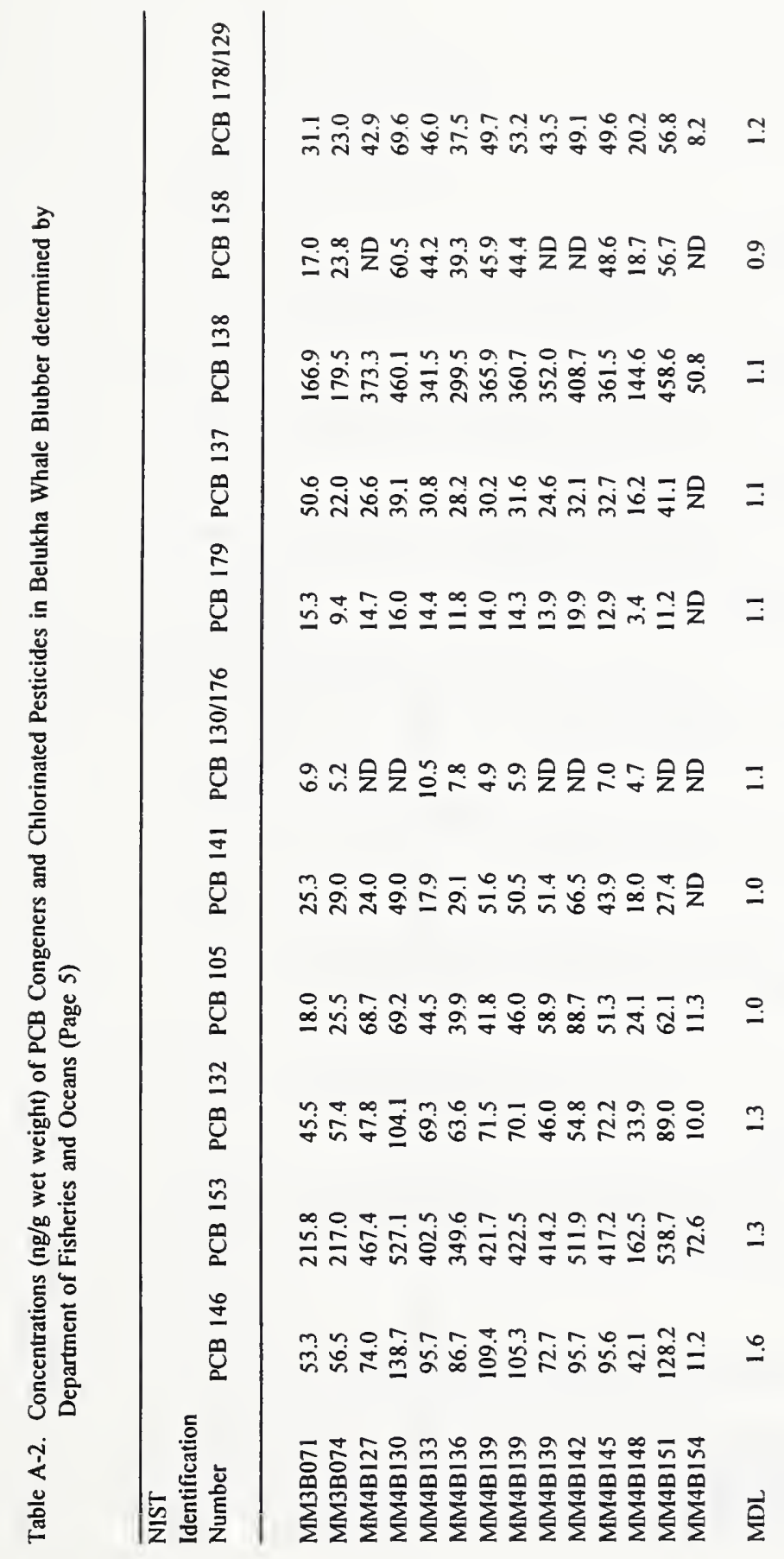




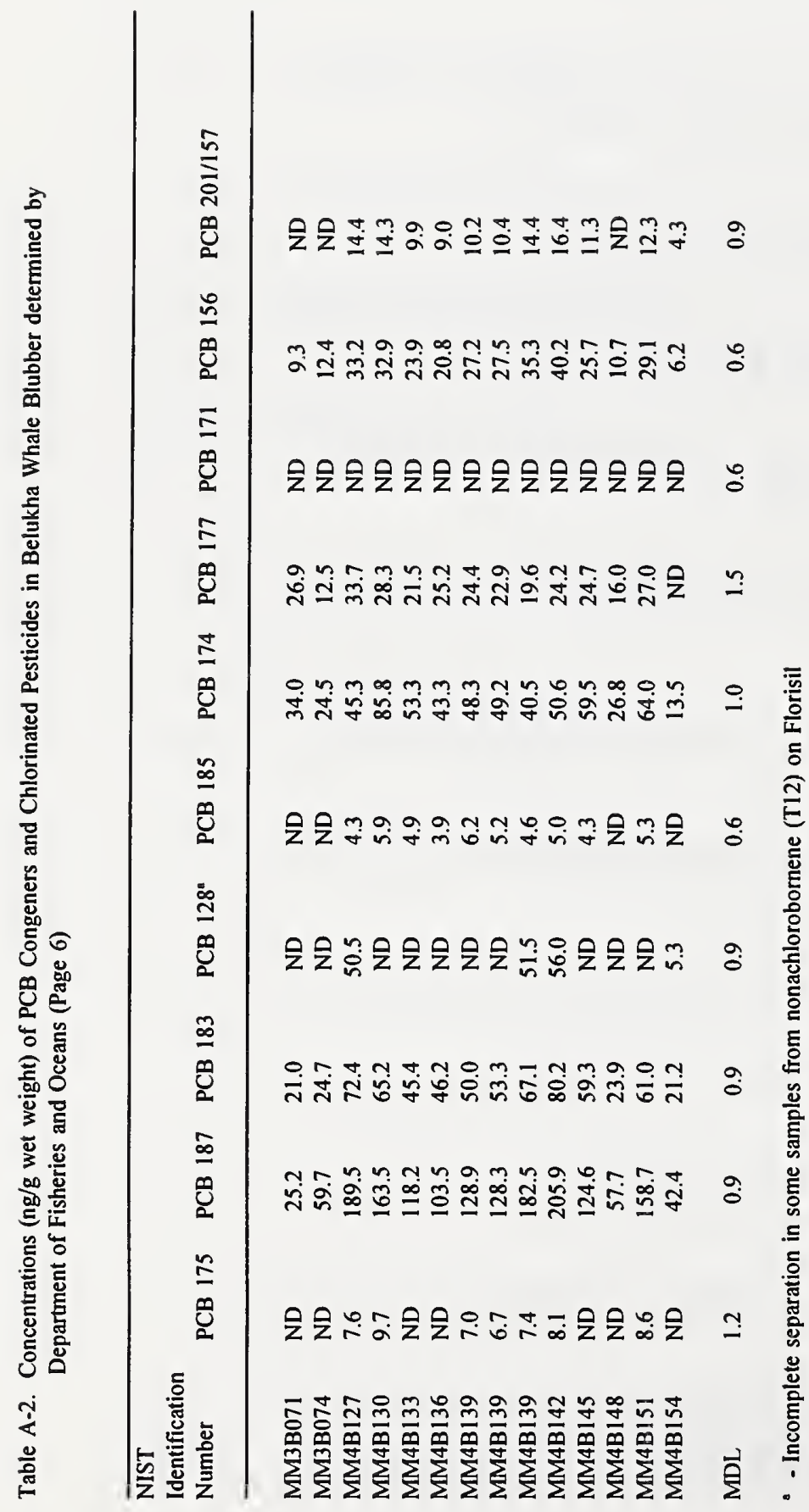




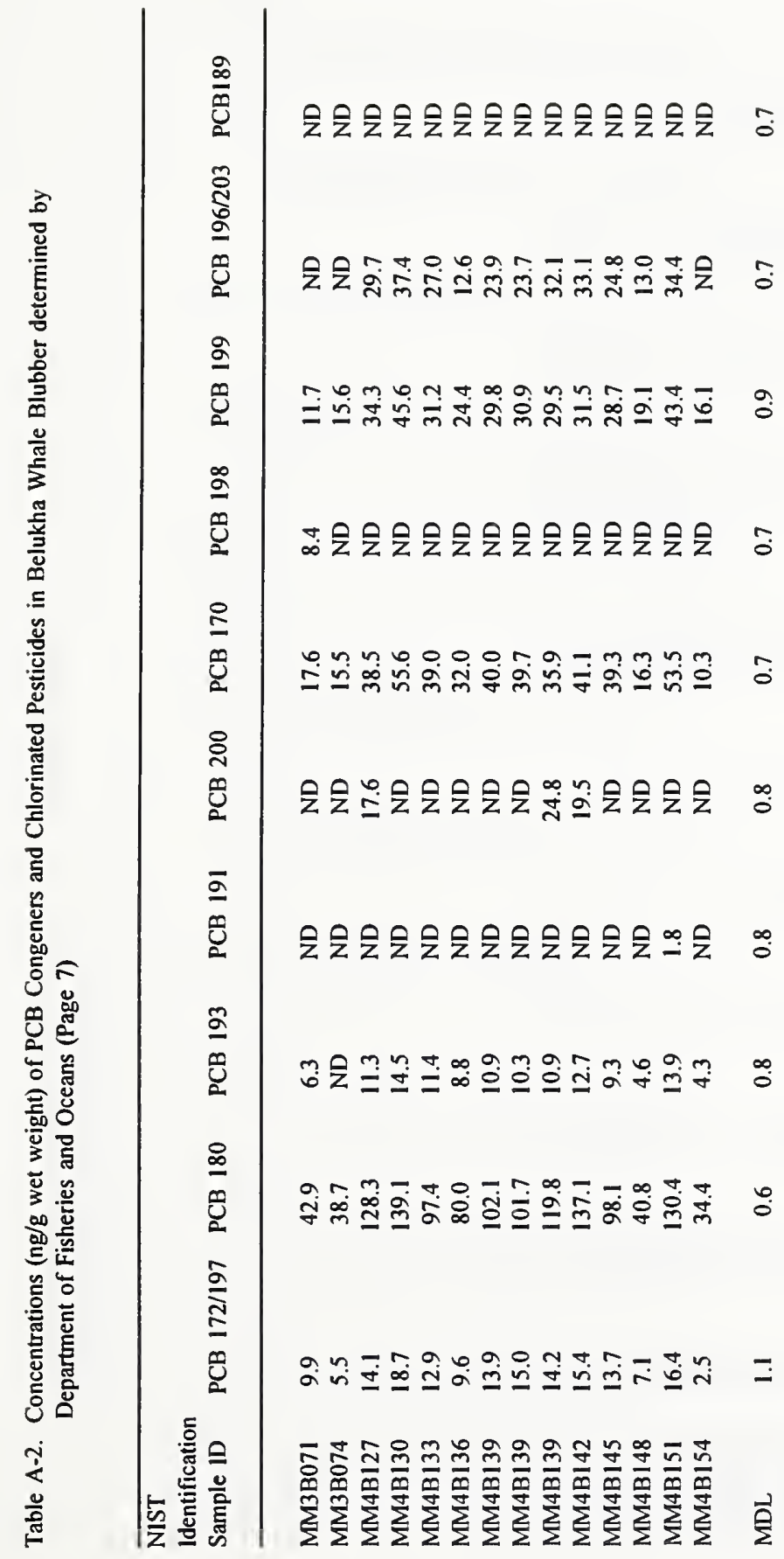




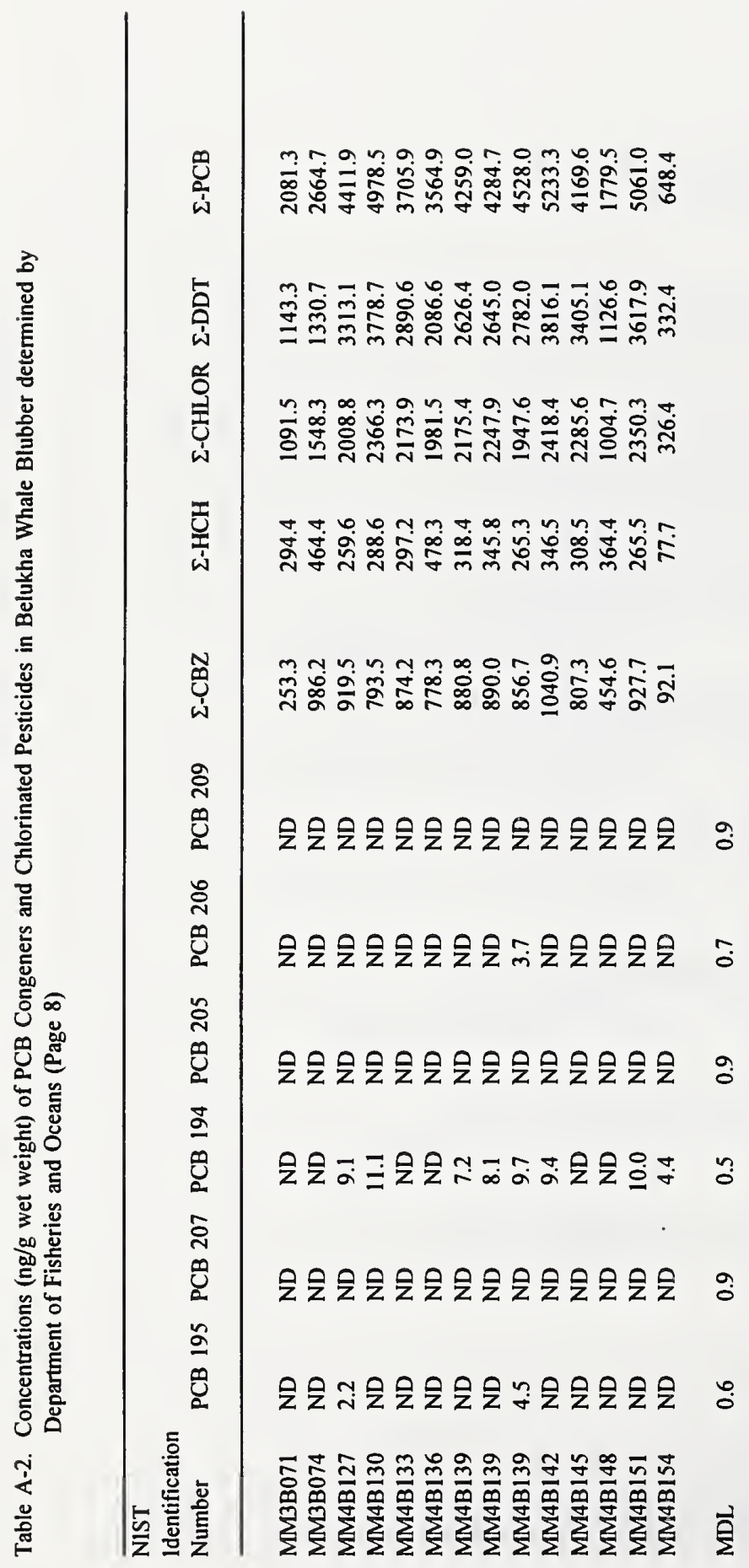




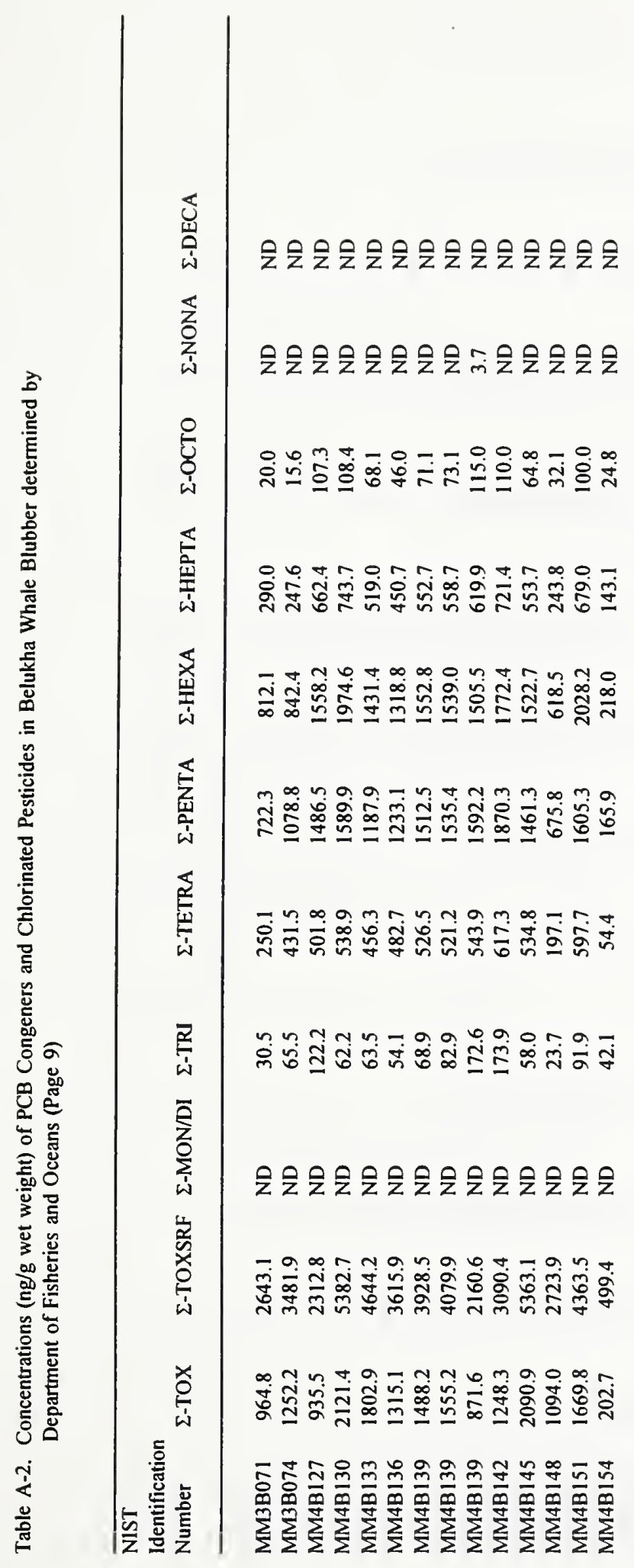




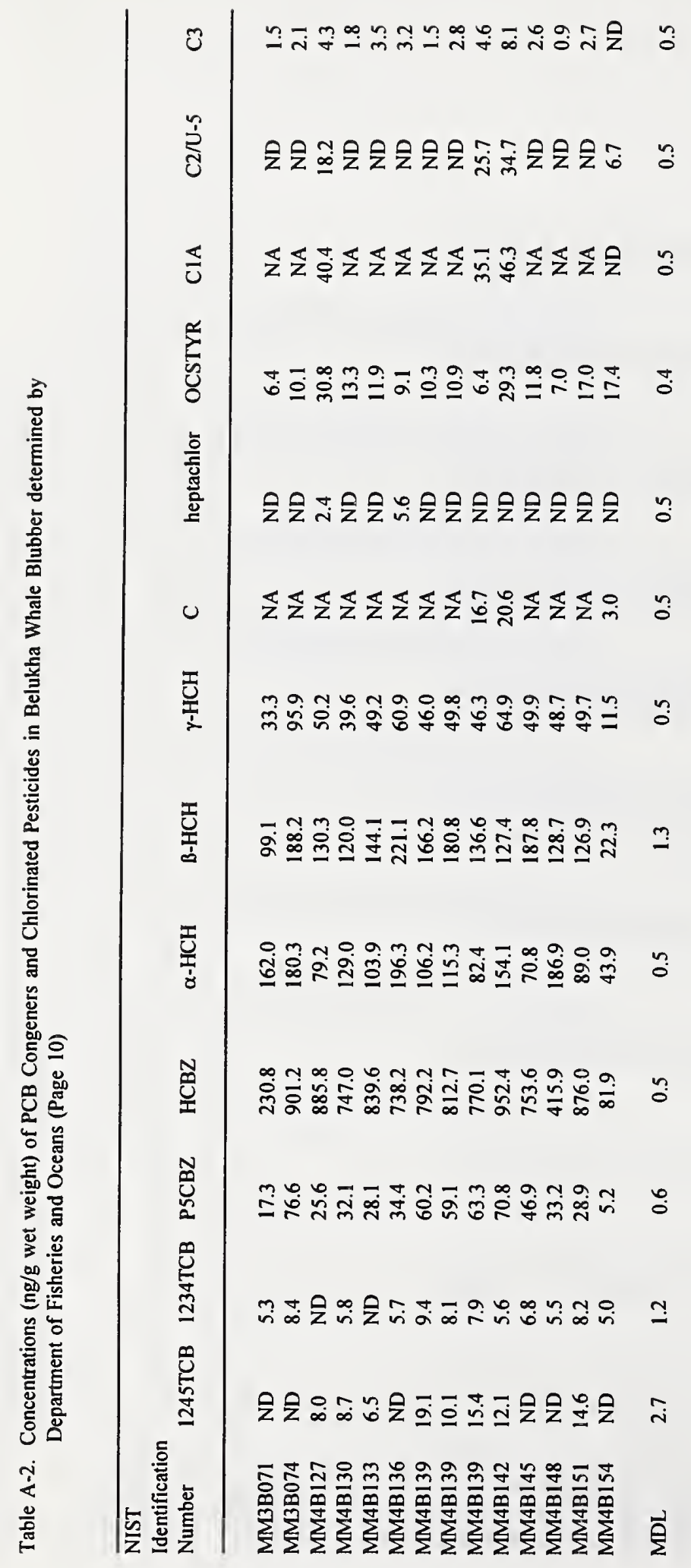




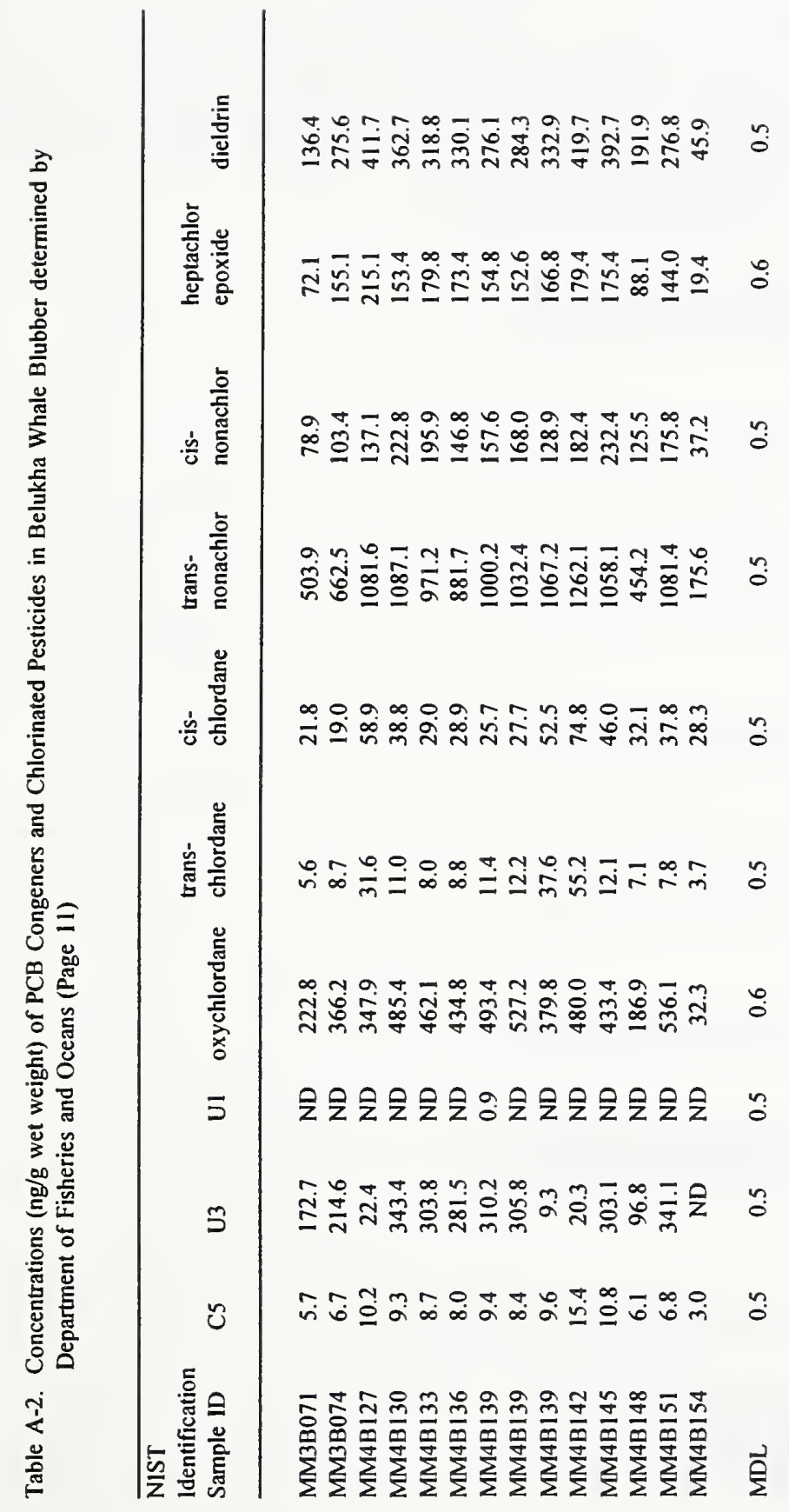




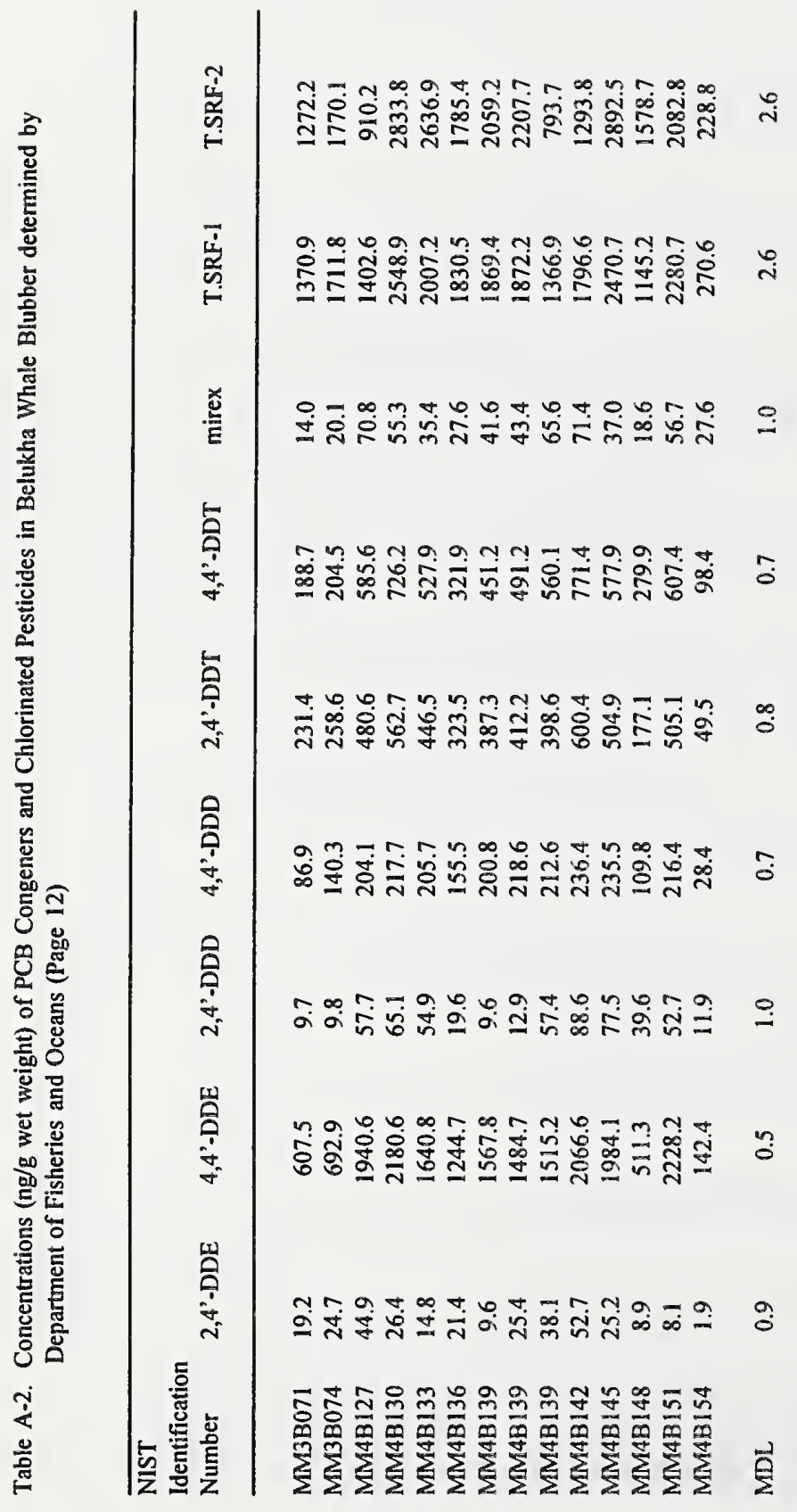




\section{APPENDIX B}

QUALITY CONTROL IN ORGANIC ANALYSIS:

INTERLABORATORY COMPARISON OF ANALYSIS OF BELUKHA WHALE BLUBBER, SRM 1588, AND QA WHALE BLUBBER HOMOGENATE 


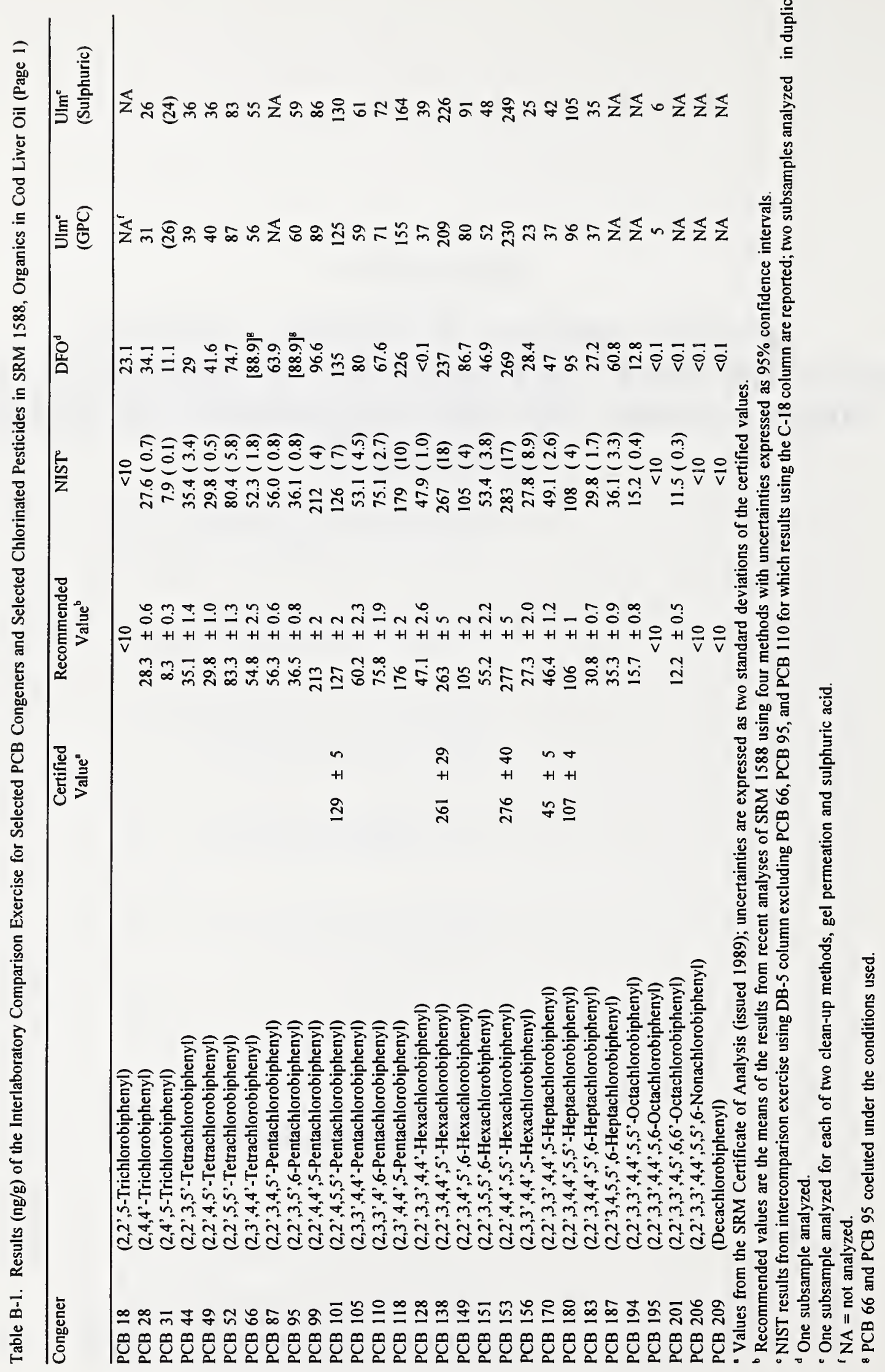




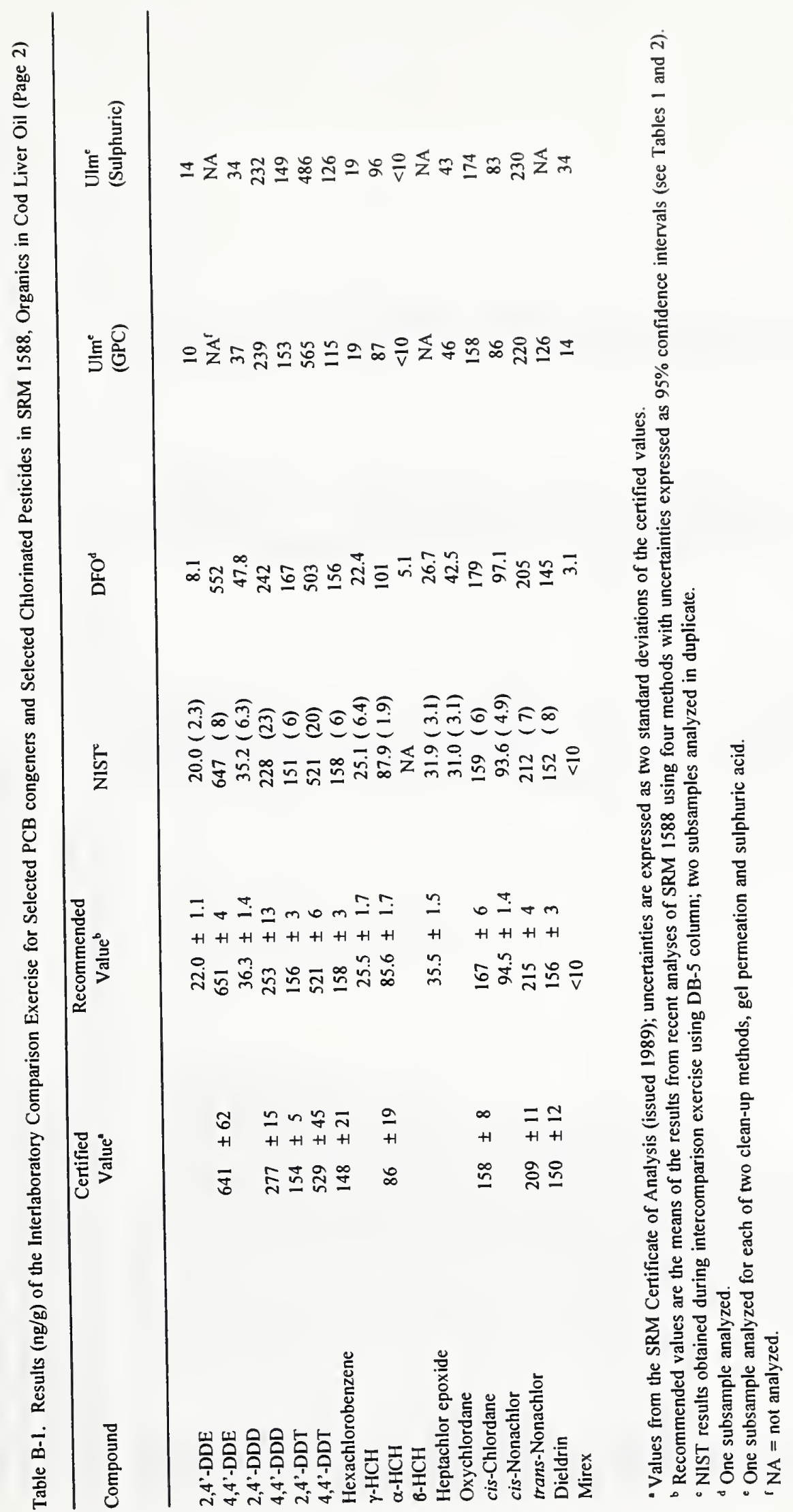



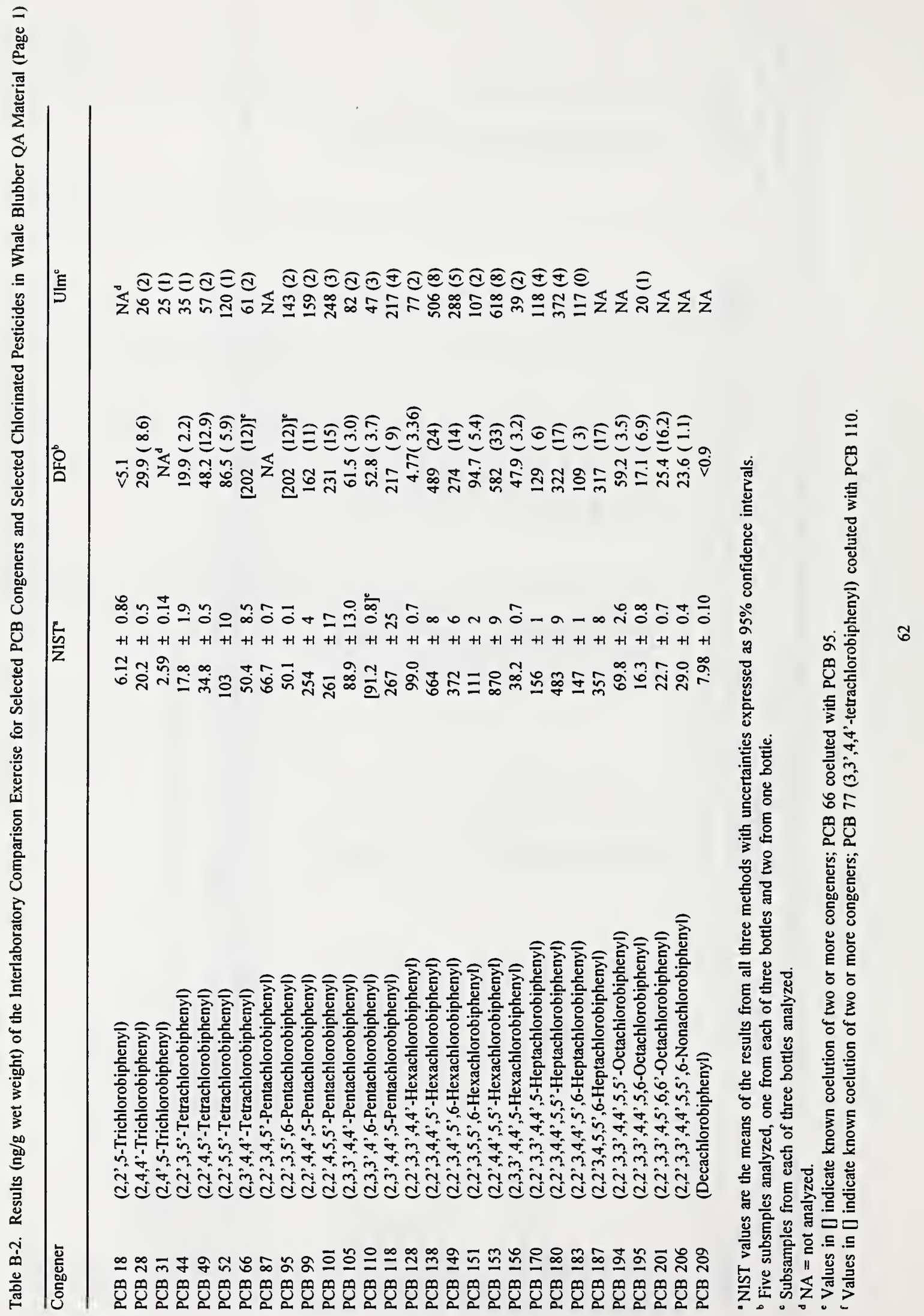


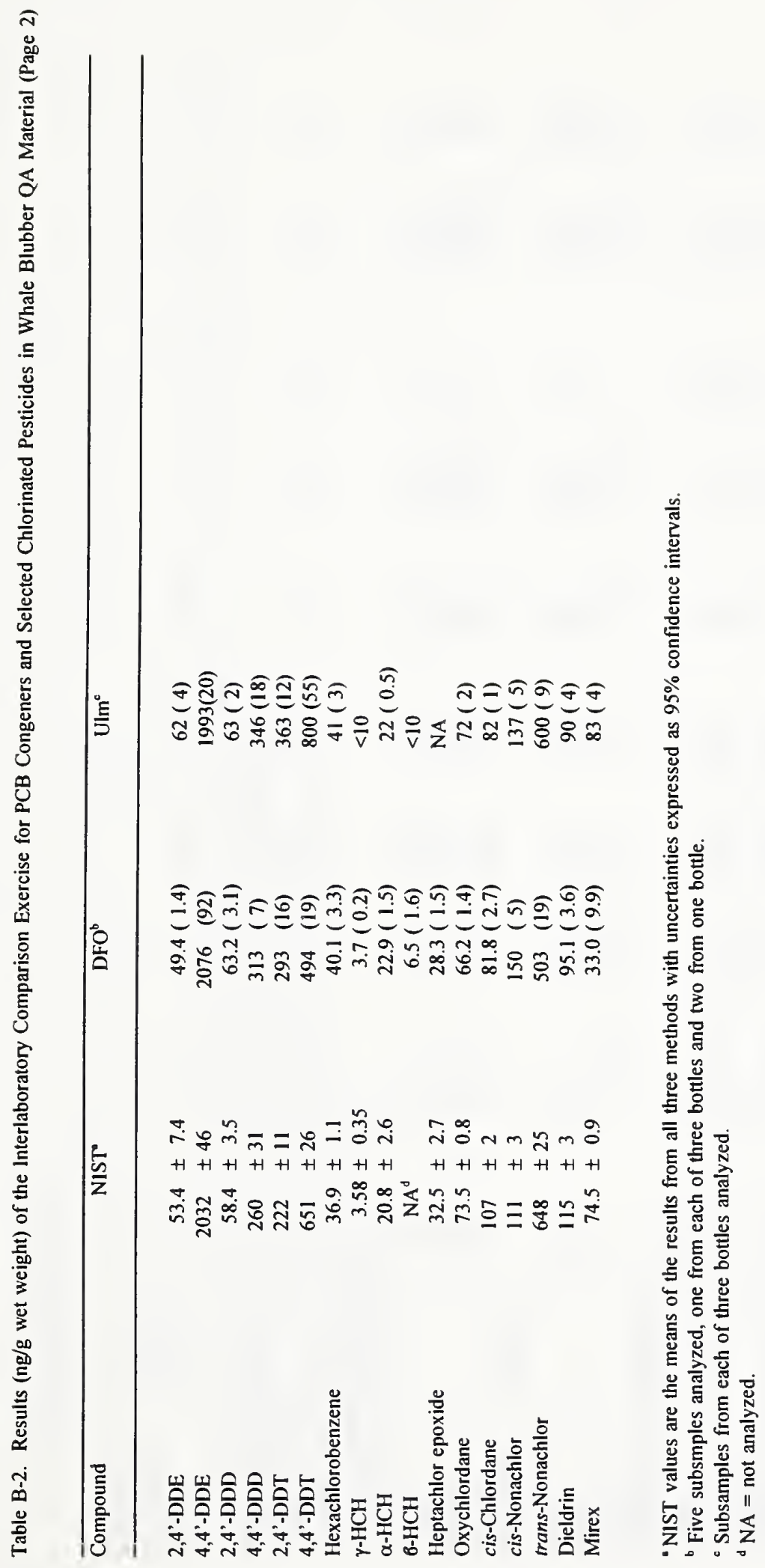




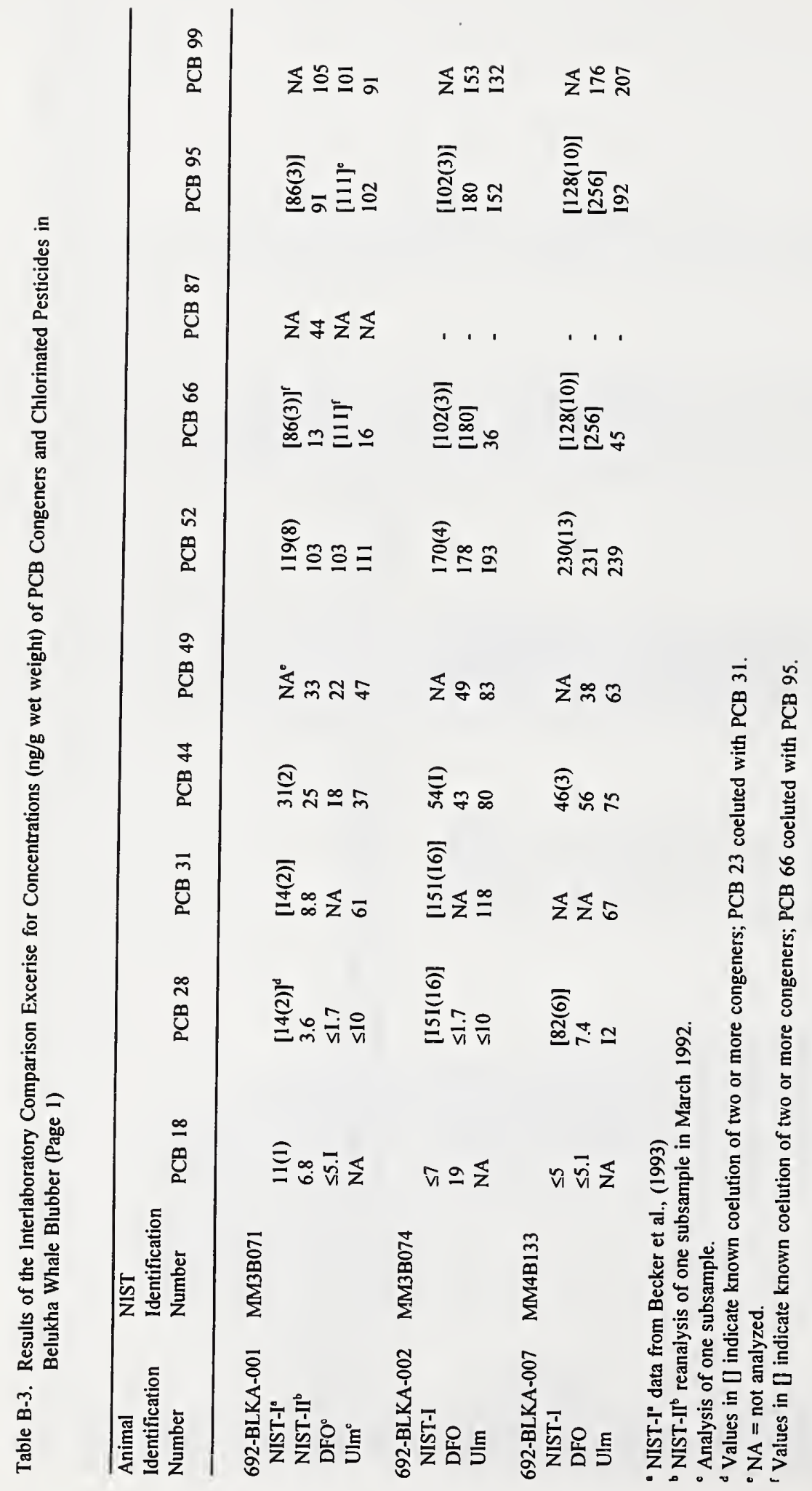




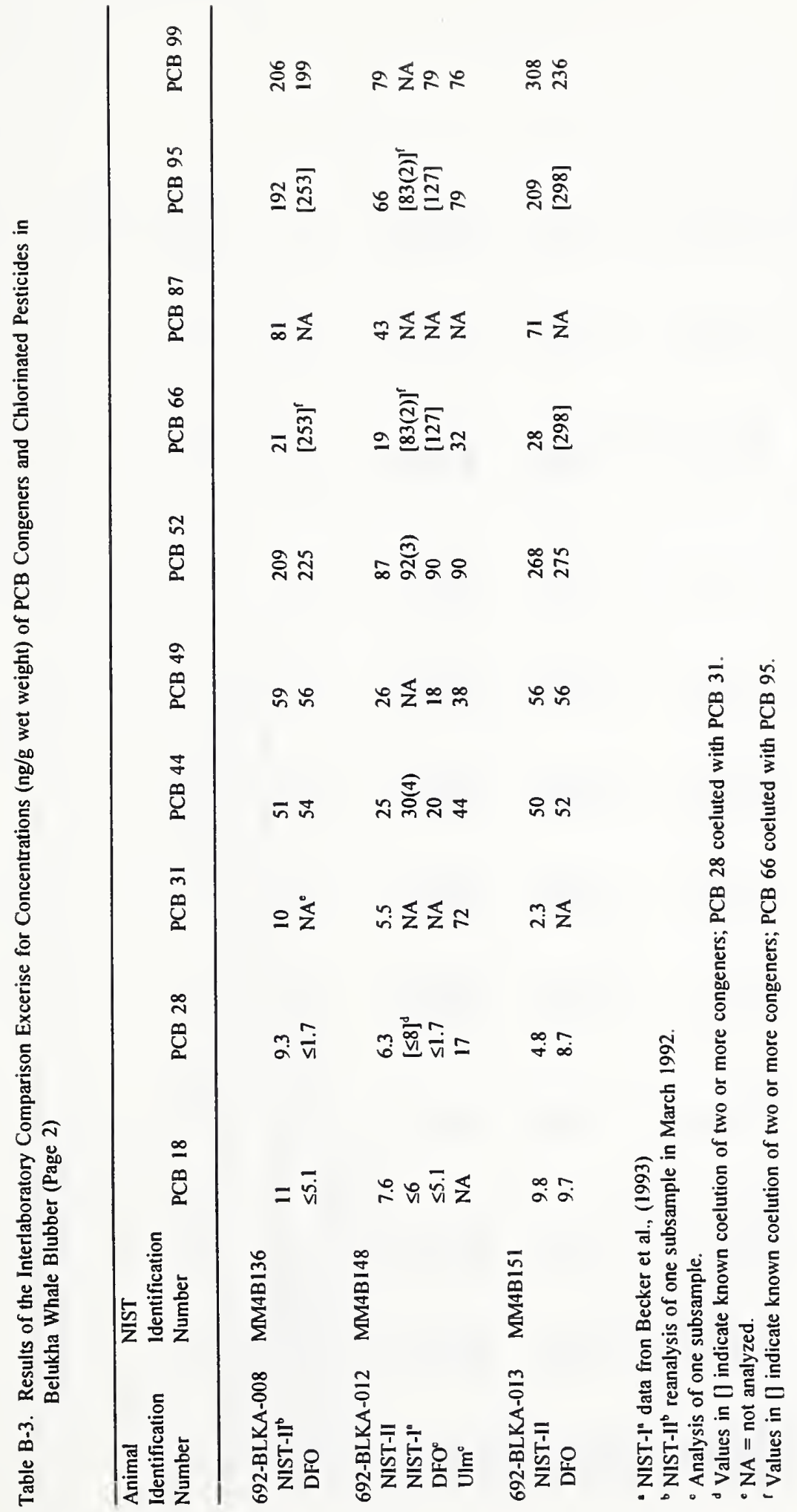




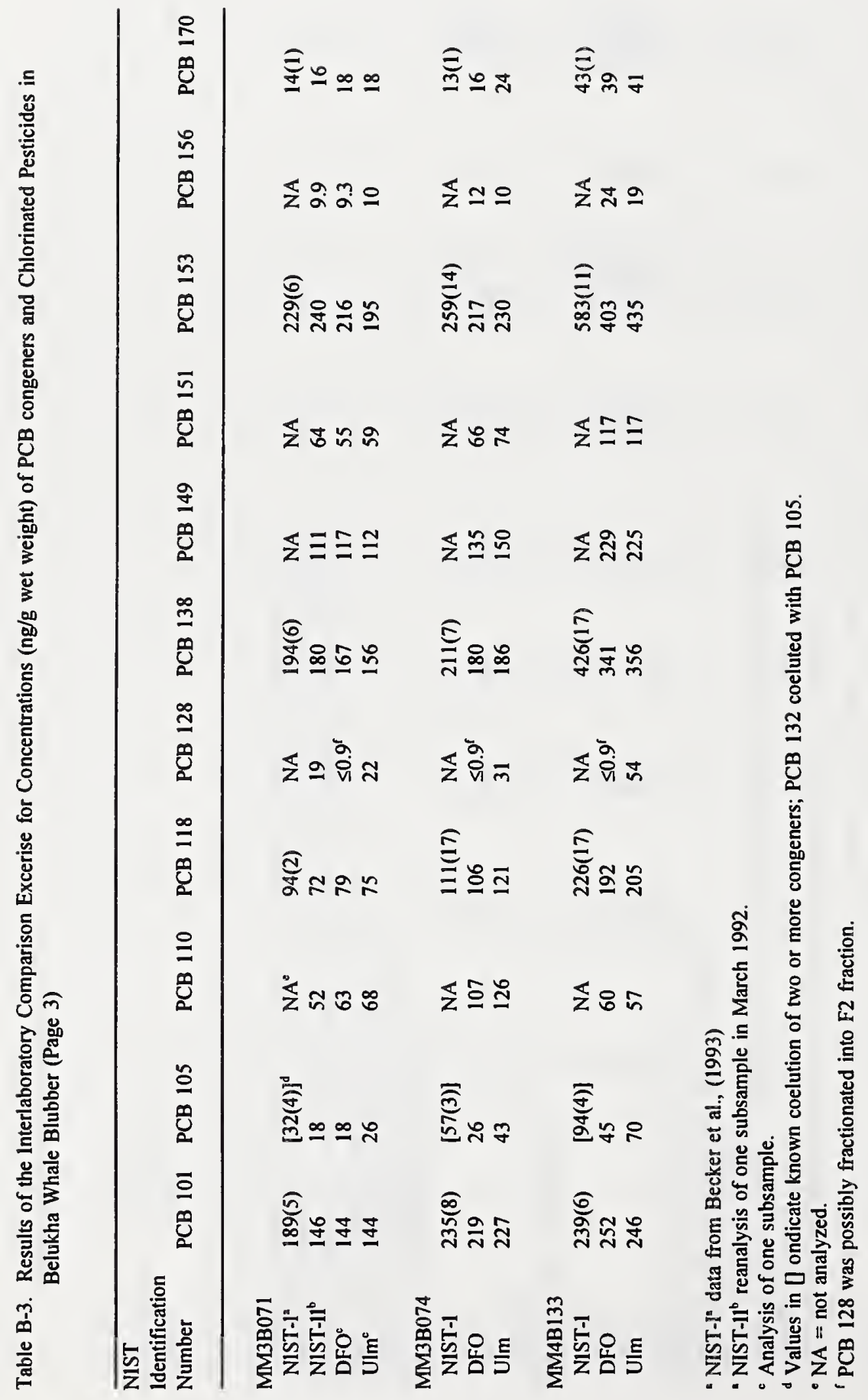




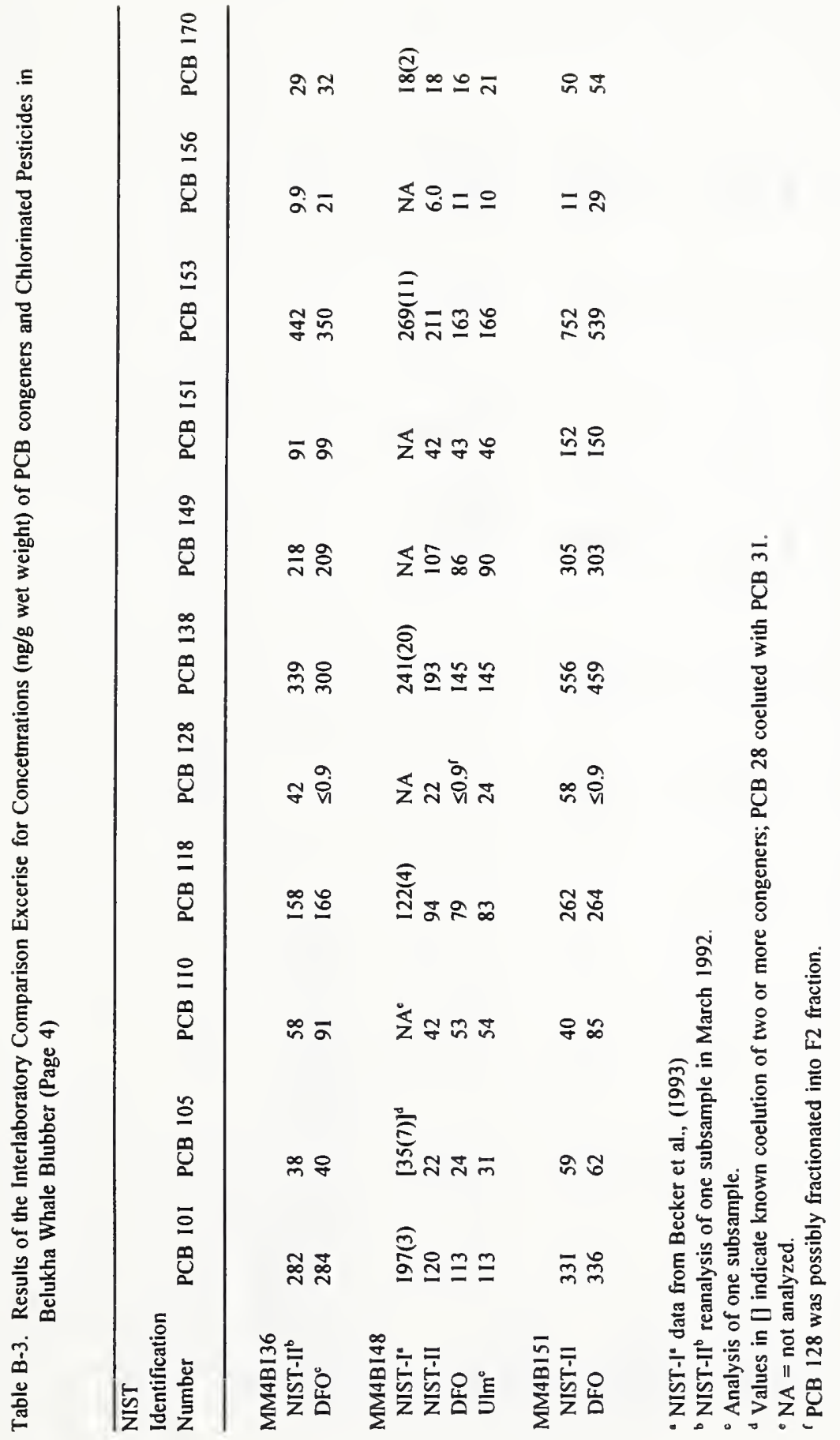




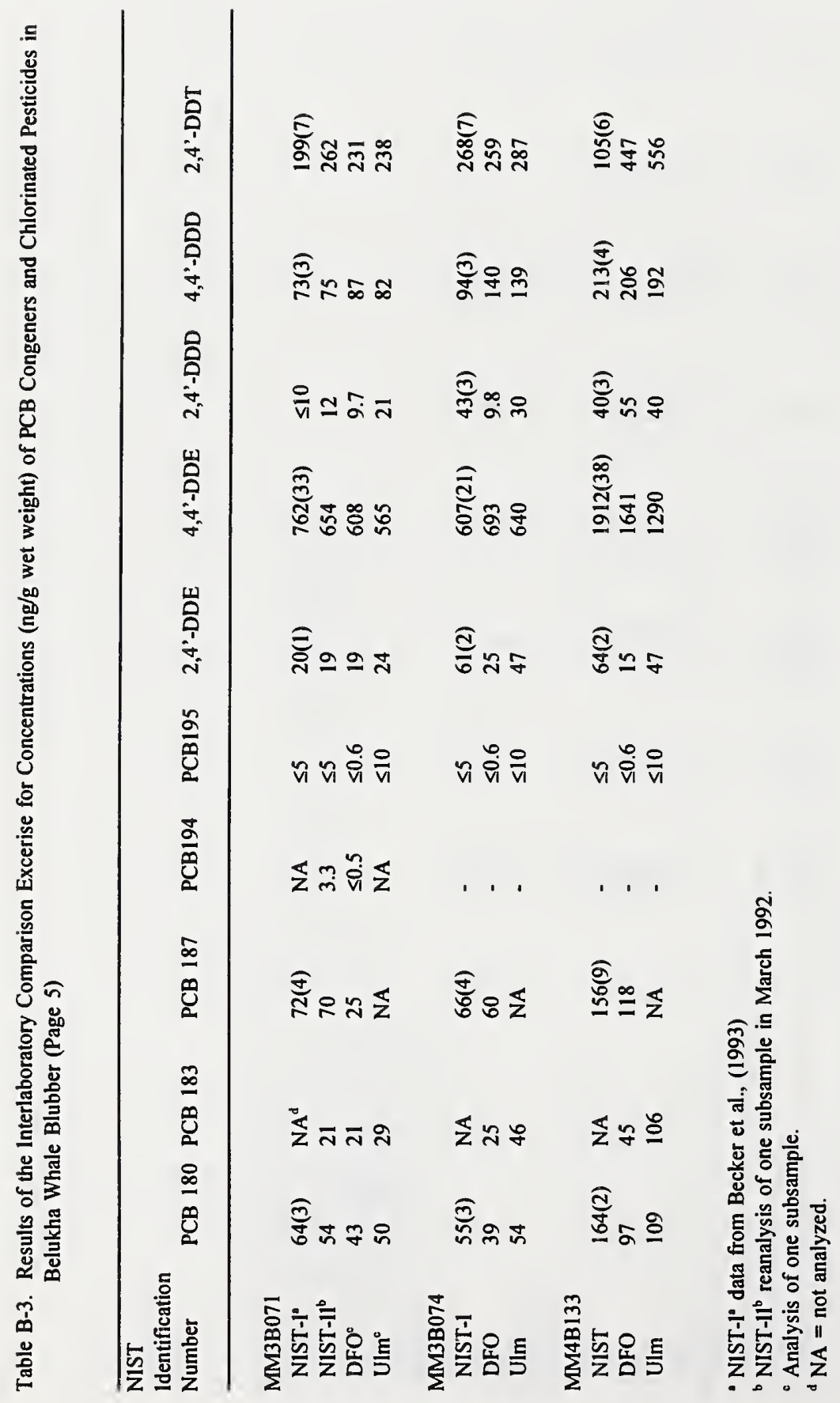




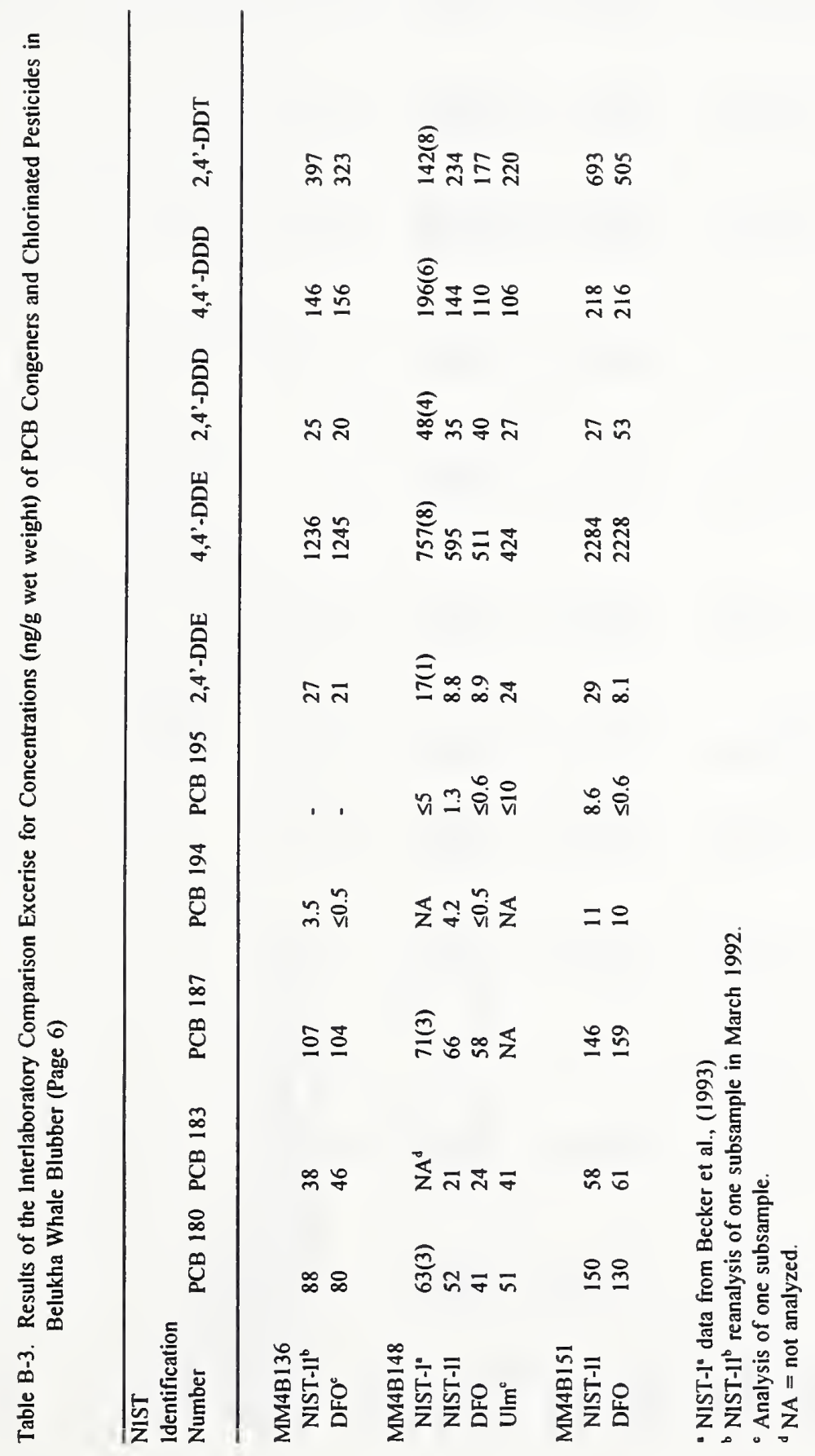




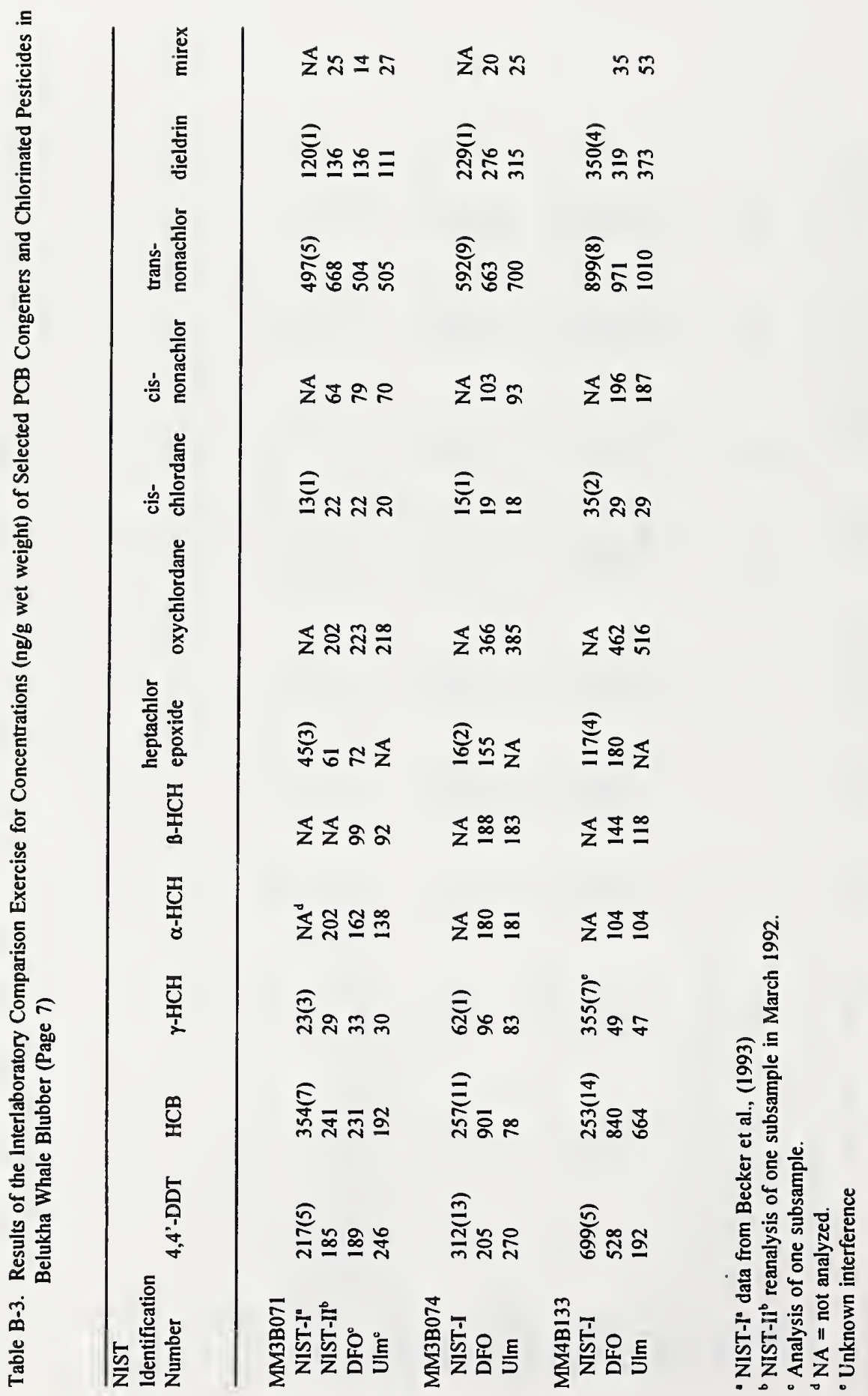




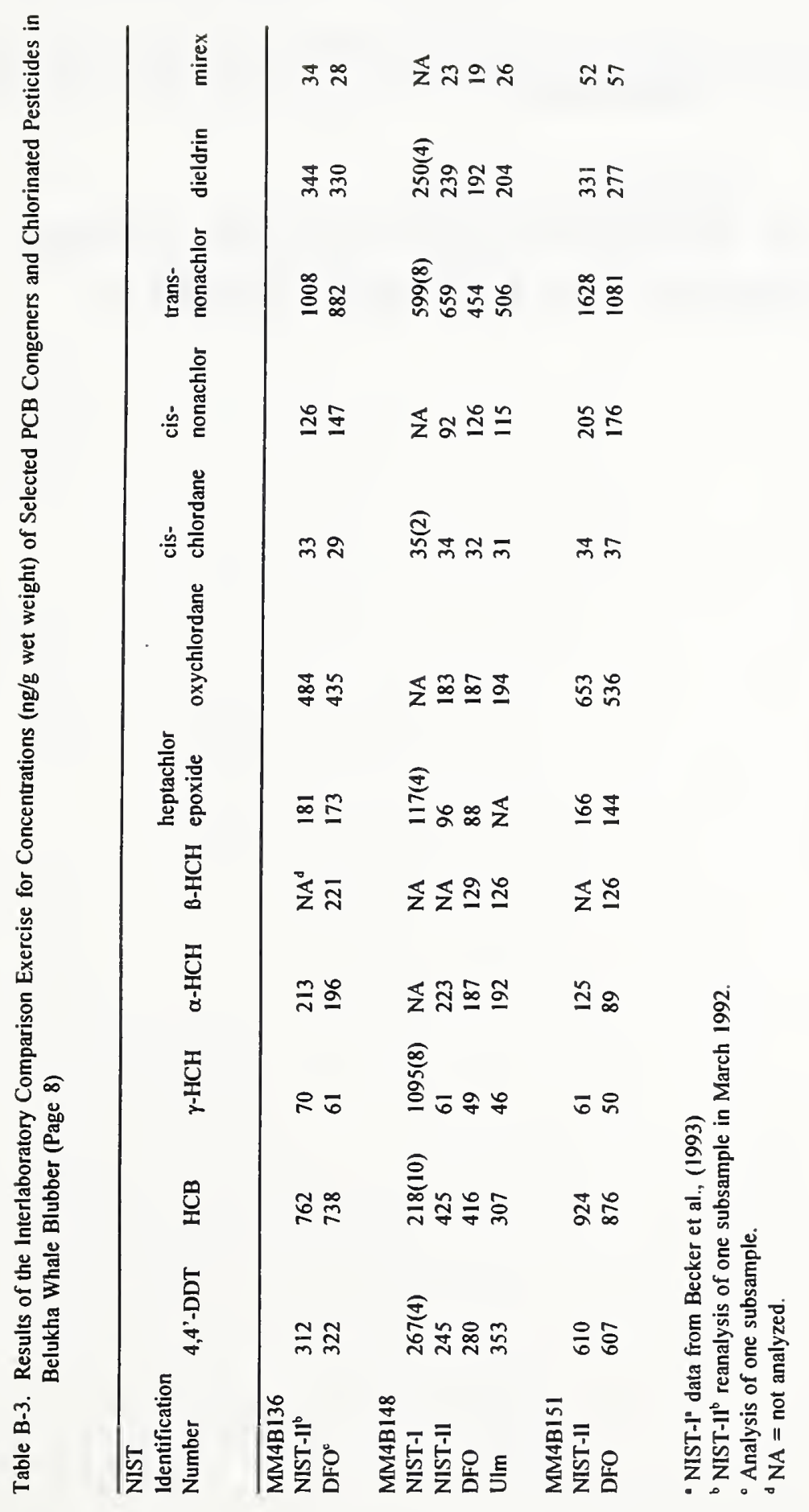




\section{APPENDIX C}

\section{ELEMENT DATA:}

LIVER TISSUE OF PINNIPEDS FROM NORTON SOUND, BELUKHA WHALES AND BOWHEAD WHALES 
Typical detection limits for these elements in marine mammal liver tissue are listed in Table C- 1 . Element concentration data for duplicate subsamples of the liver specimens are presented in Tables C-2 - C-6. Table C-2 presents data from ringed seals sampled in Norton Sound in 1989 and 1991. The concentration values for RGSL-011 and RGSL-012 have been previously reported in Becker et al. (1992) and Zeisler et al. (1993). Table C-3 presents data from a bearded seal and Table C-4 presents data from a spotted seal sampled in Norton Sound in 1989 and 1991, respectively. Table C-5 presents data from belukha whales sampled at Point Hope in 1989, Point Lay in 1990 and Cook Inlet in 1992. The concentration values for BLKA-001, -002, -003, -004, -007 and -012 have been previously reported by Becker et al. (1992) and Zeisler et al. (1993). Table C-6 presents data from bowhead whales sampled at Barrow in 1992.

Concentration values are expressed as $\mu \mathrm{g} / \mathrm{g}$, wet weight, and dry weight conversion factors for each sample are listed in Table C-7; NA indicates that there was no analysis. 
Table C-1. Range of INAA detection limits for elements in marine mammal liver tissues.

\begin{tabular}{lc}
\hline ELEMENTS & LIMITS OF DETECTION $(\mu \mathrm{g} / \mathrm{g})$ \\
\hline $\mathrm{Sc}$ & $0.00007-0.0002$ \\
$\mathrm{Sr}$ & $0.5-2$ \\
$\mathrm{Mo}$ & $0.13-1.1$ \\
$\mathrm{Sn}$ & $1-2$ \\
$\mathrm{Ba}$ & $3-25$ \\
$\mathrm{La}$ & $0.002-0.01$ \\
$\mathrm{Ce}$ & $0.01-0.03$ \\
$\mathrm{Sm}$ & $0.0005-0.03$ \\
$\mathrm{Eu}$ & $0.0002-0.001$ \\
$\mathrm{~Tb}$ & $0.0006-0.001$ \\
$\mathrm{Hf}$ & $0.0003-0.005$ \\
$\mathrm{Ta}$ & $0.0002-0.002$ \\
$\mathrm{Au}$ & $0.0002-0.1$ \\
$\mathrm{Th}$ & $0.001-0.02$ \\
$\mathrm{U}$ & $0.03-0.7$
\end{tabular}




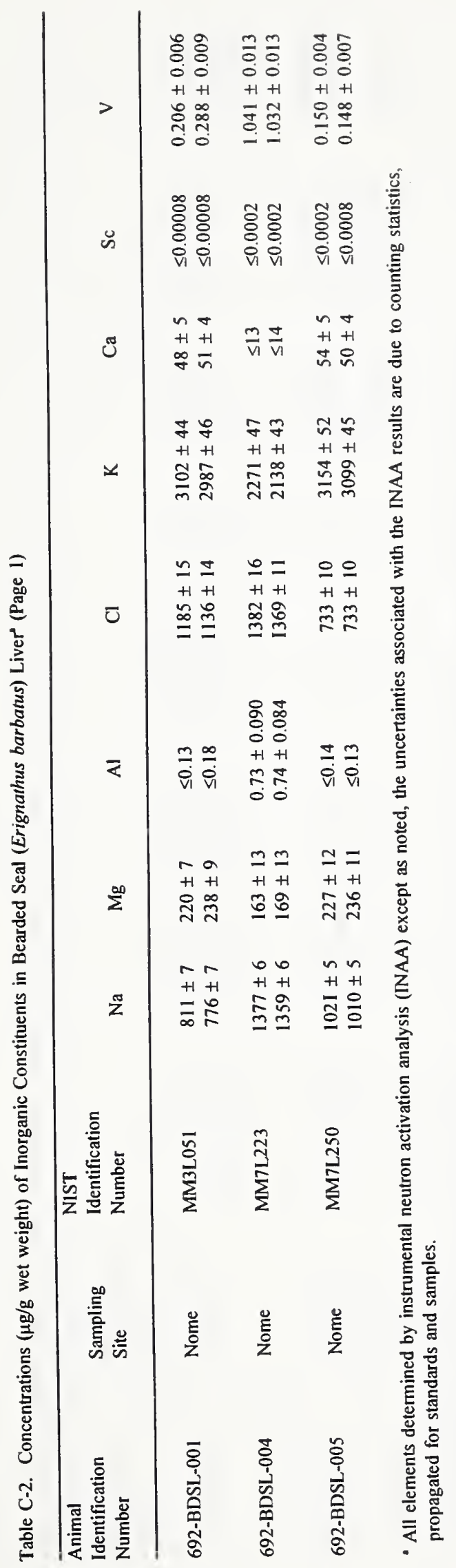




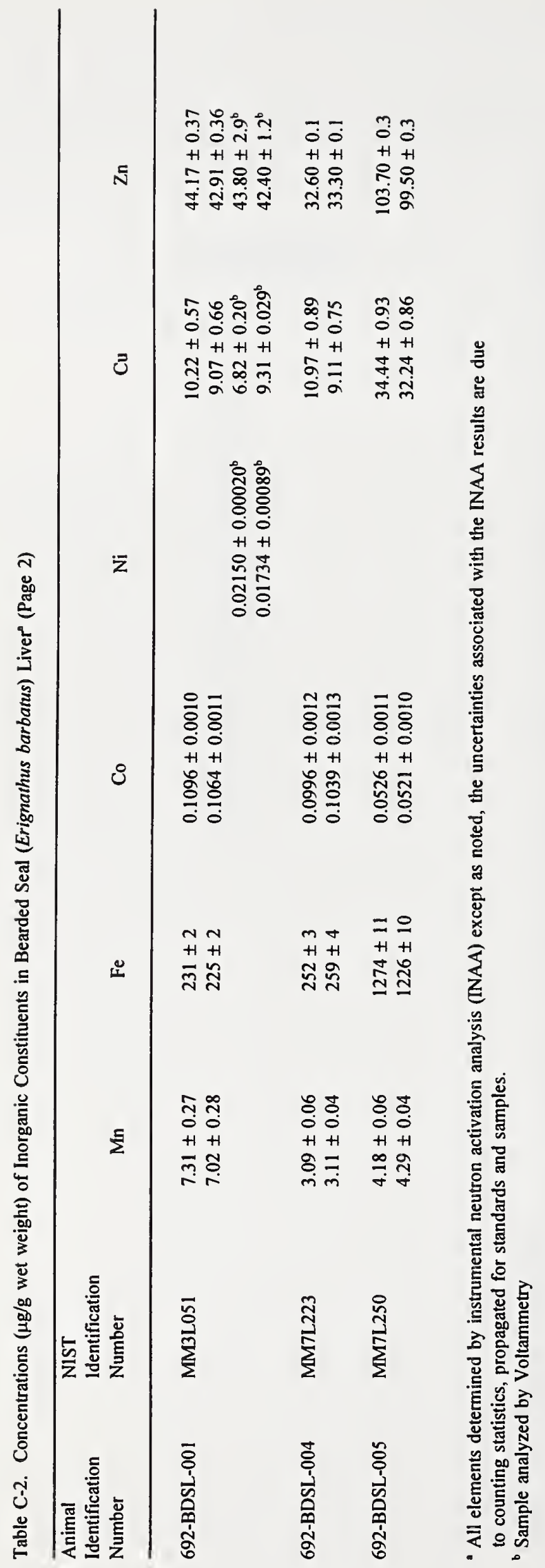




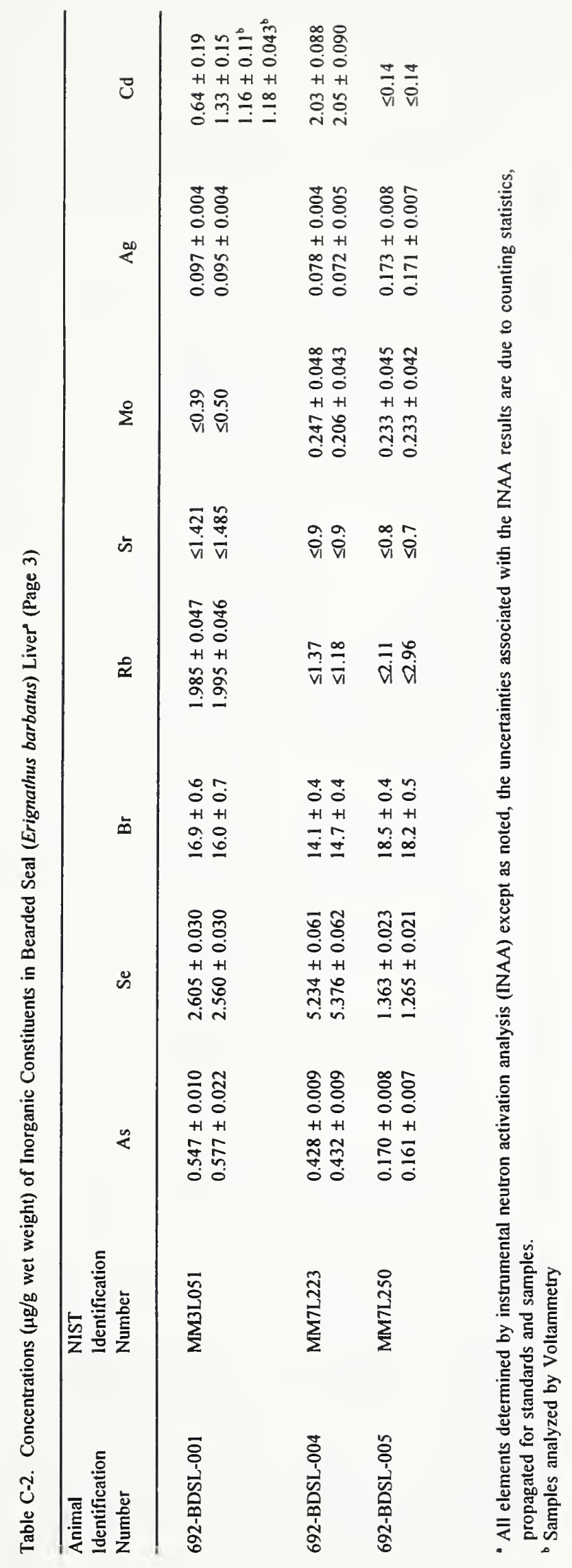




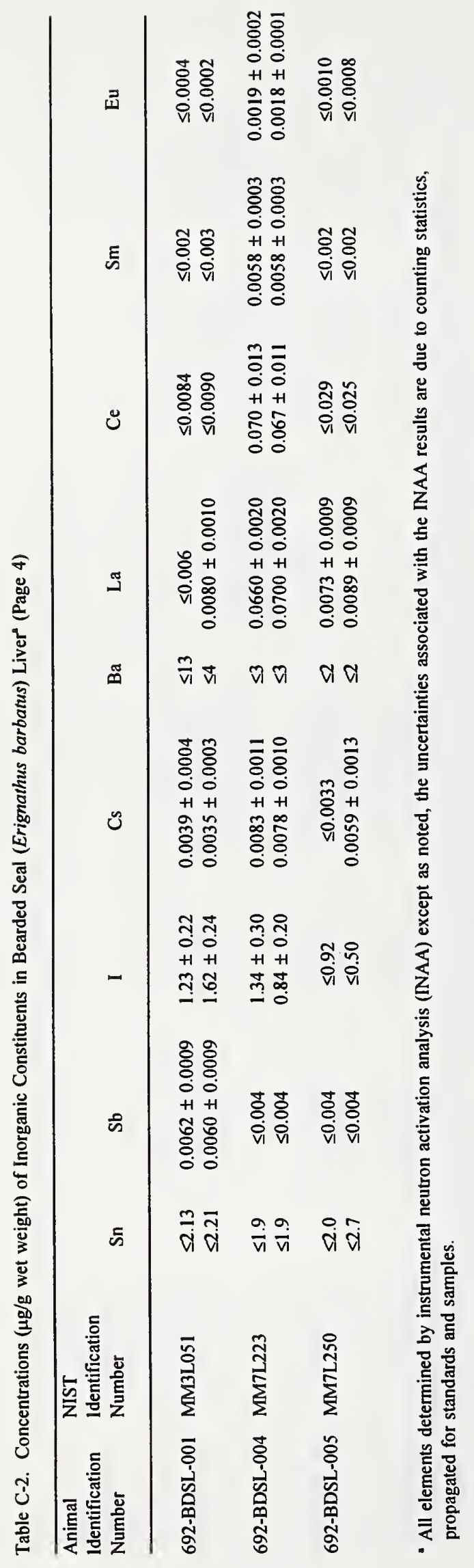




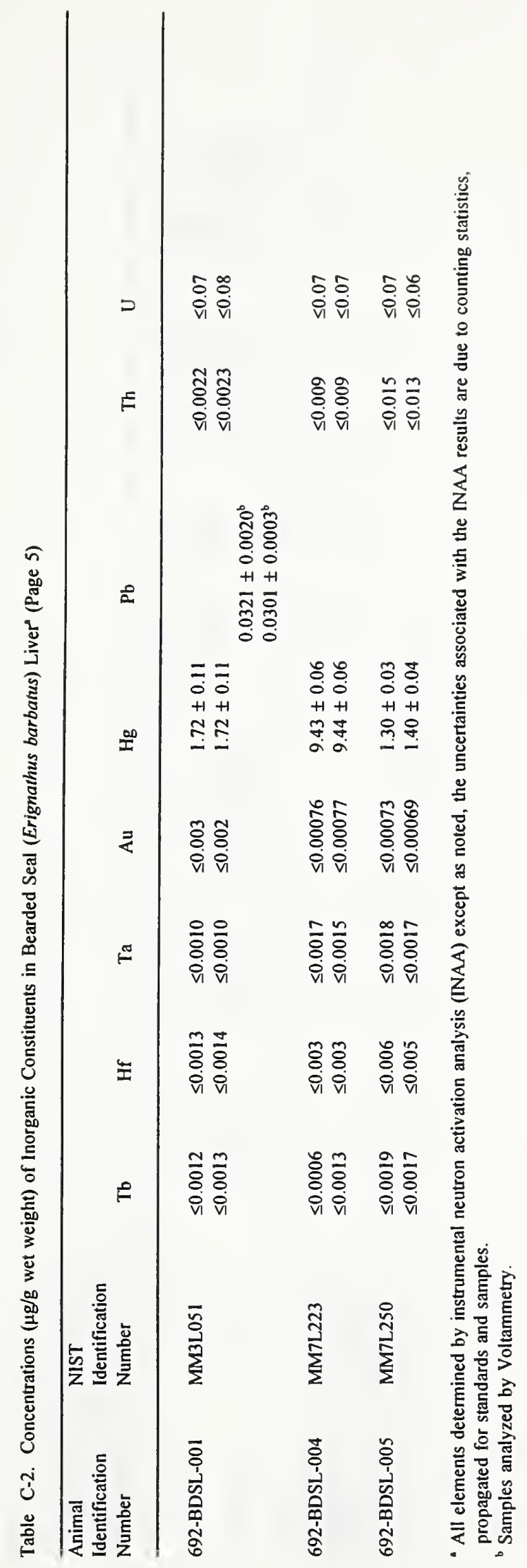



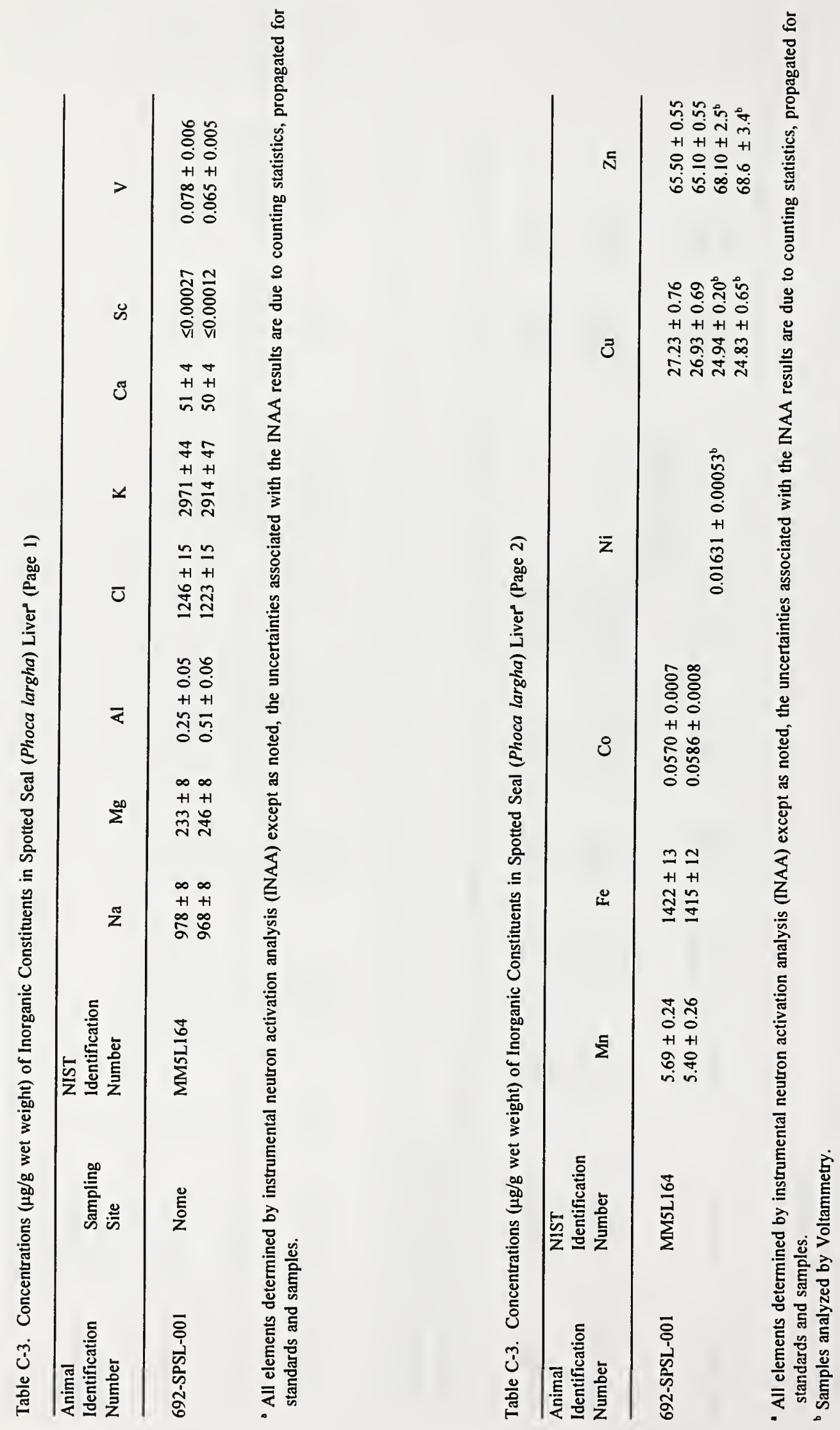

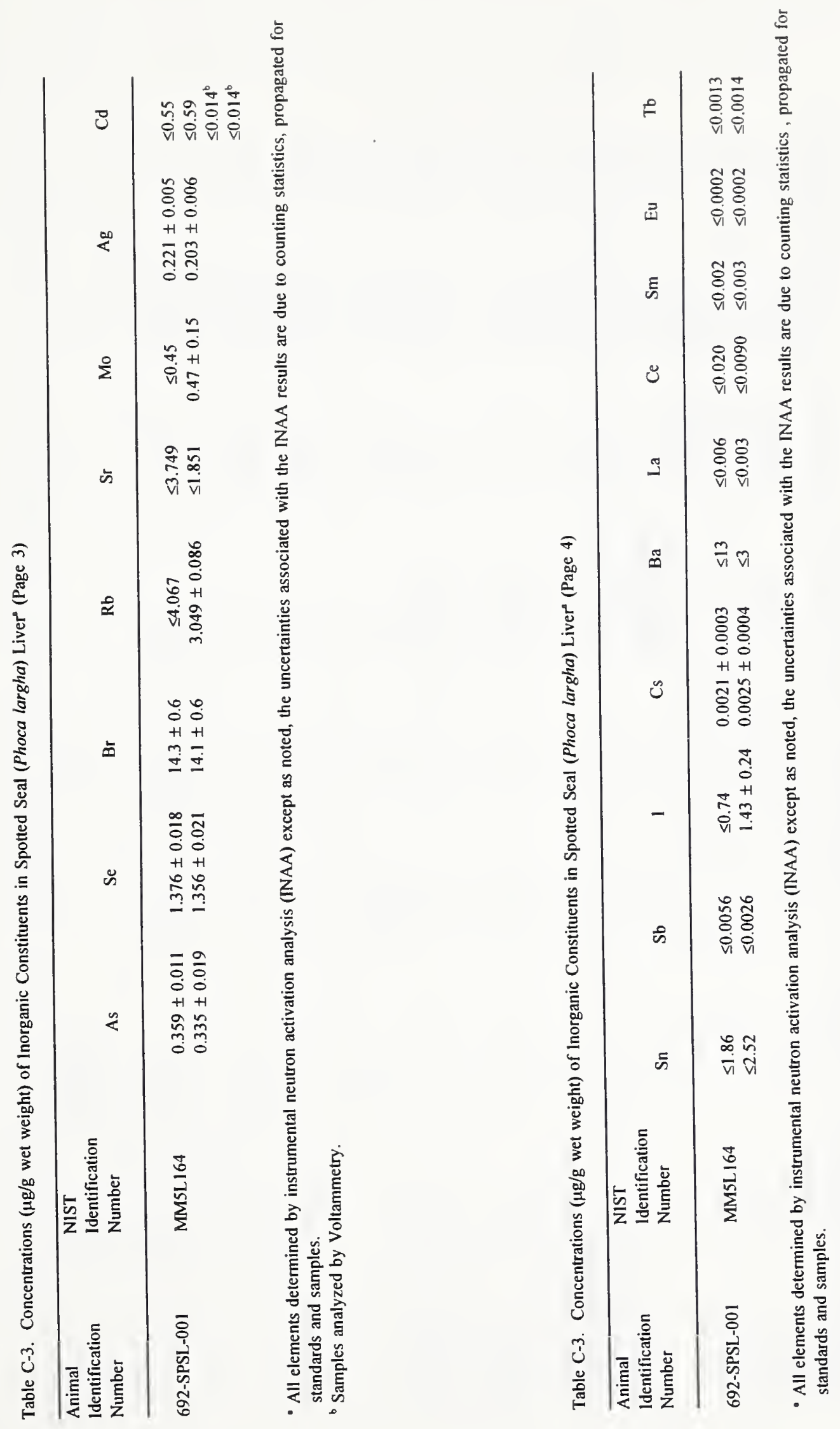


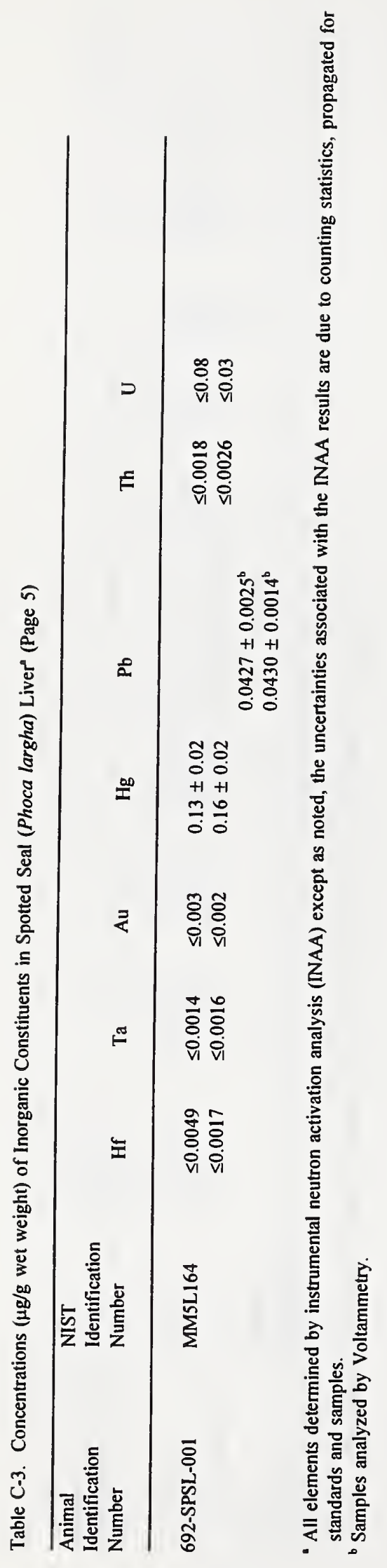




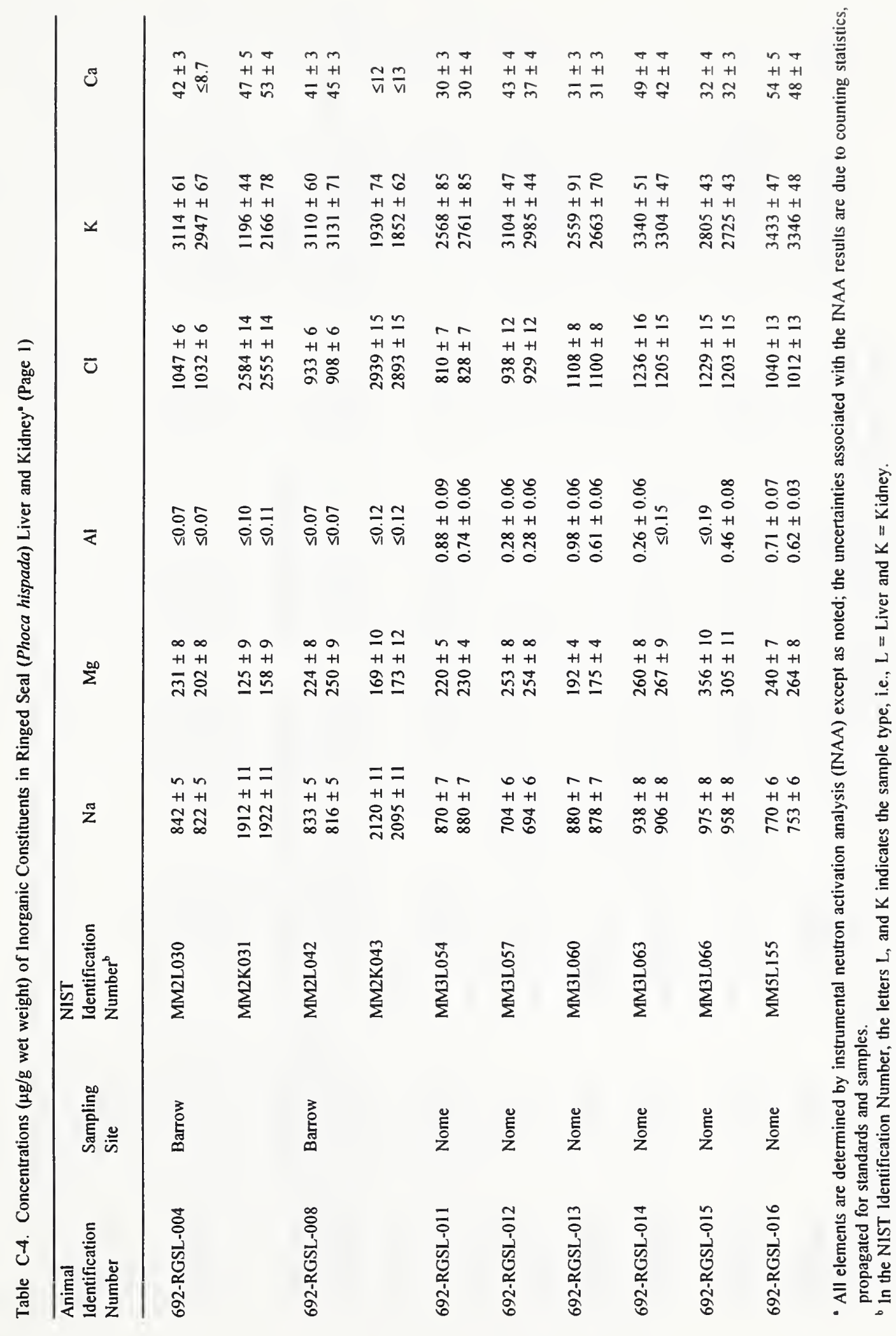




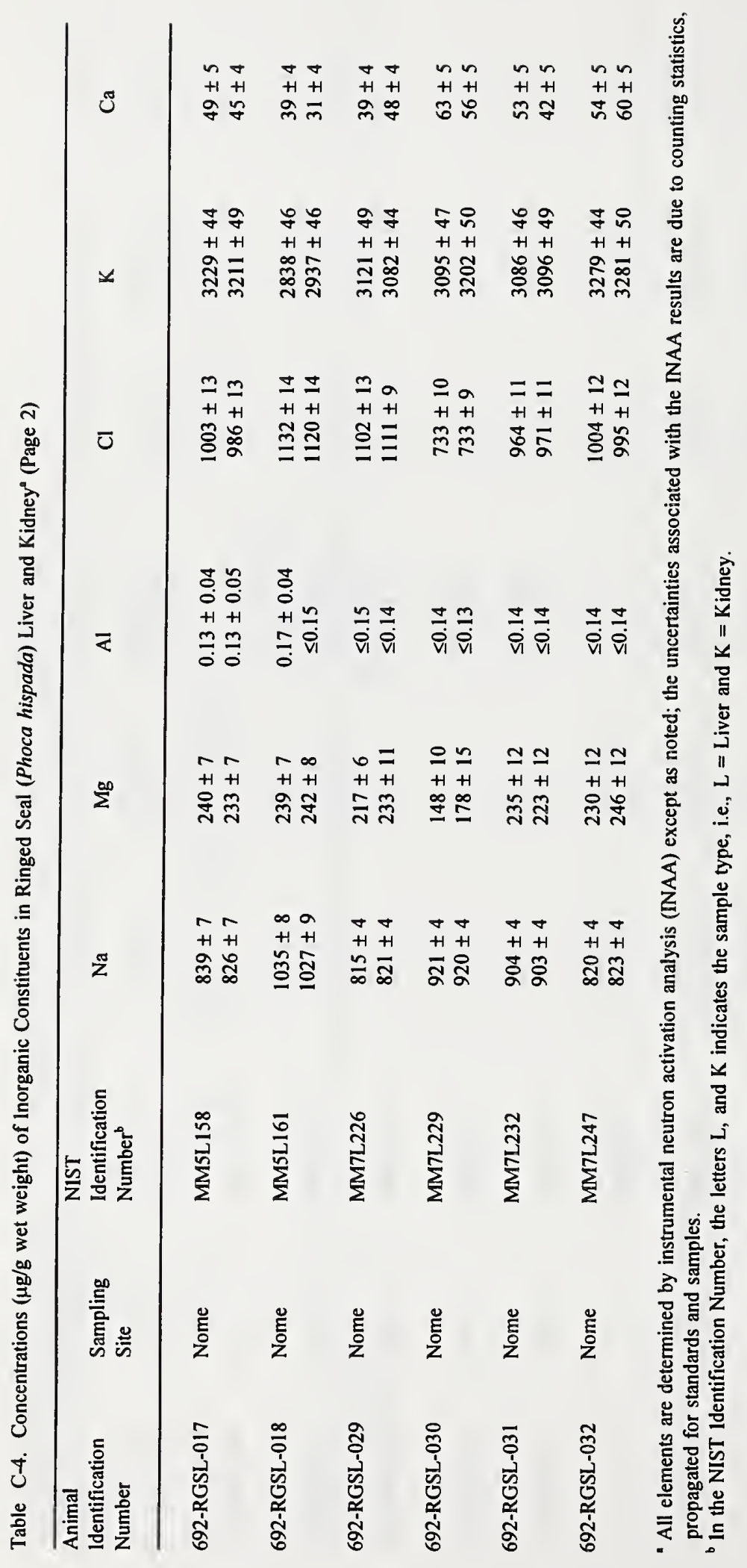




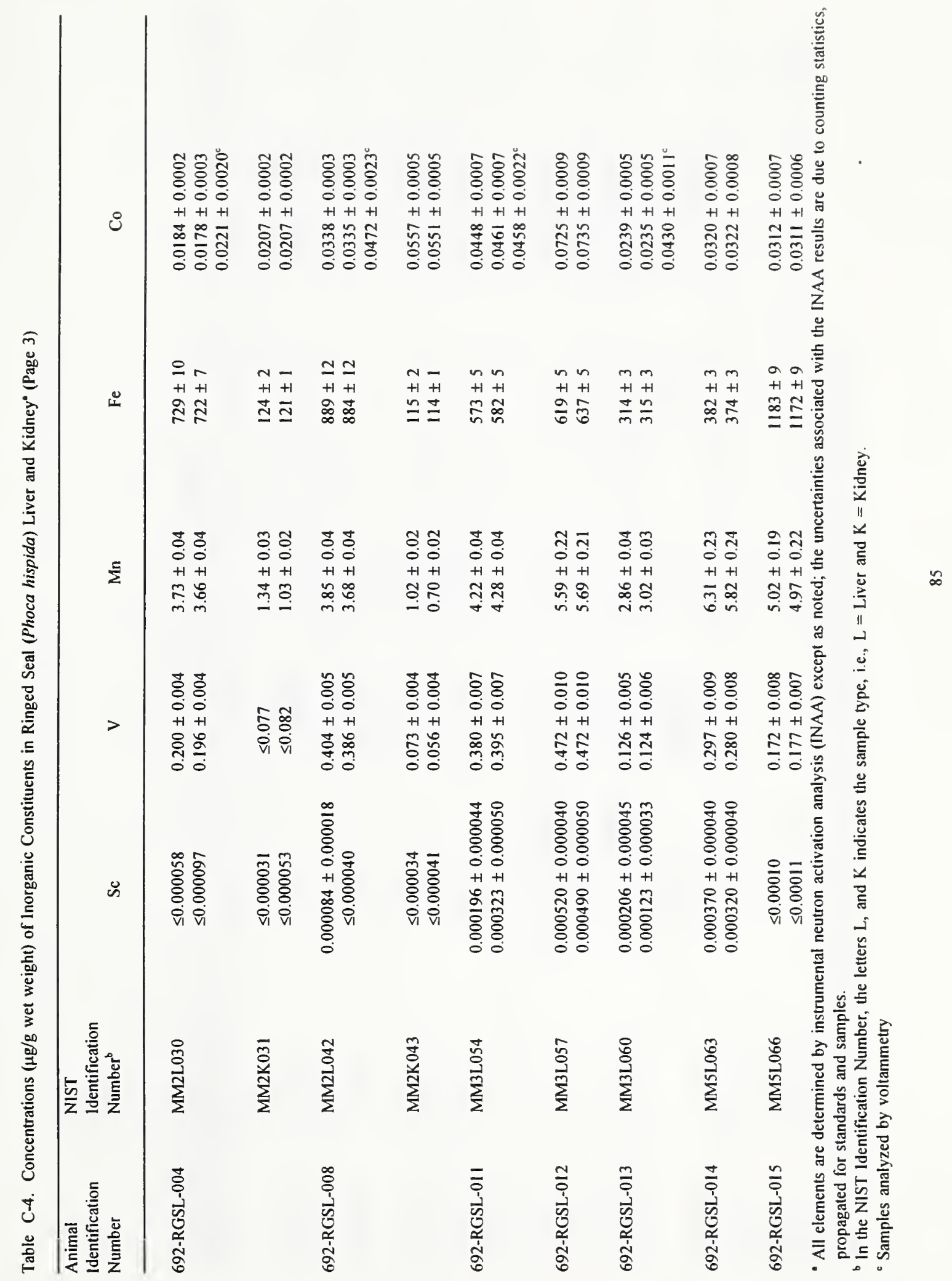




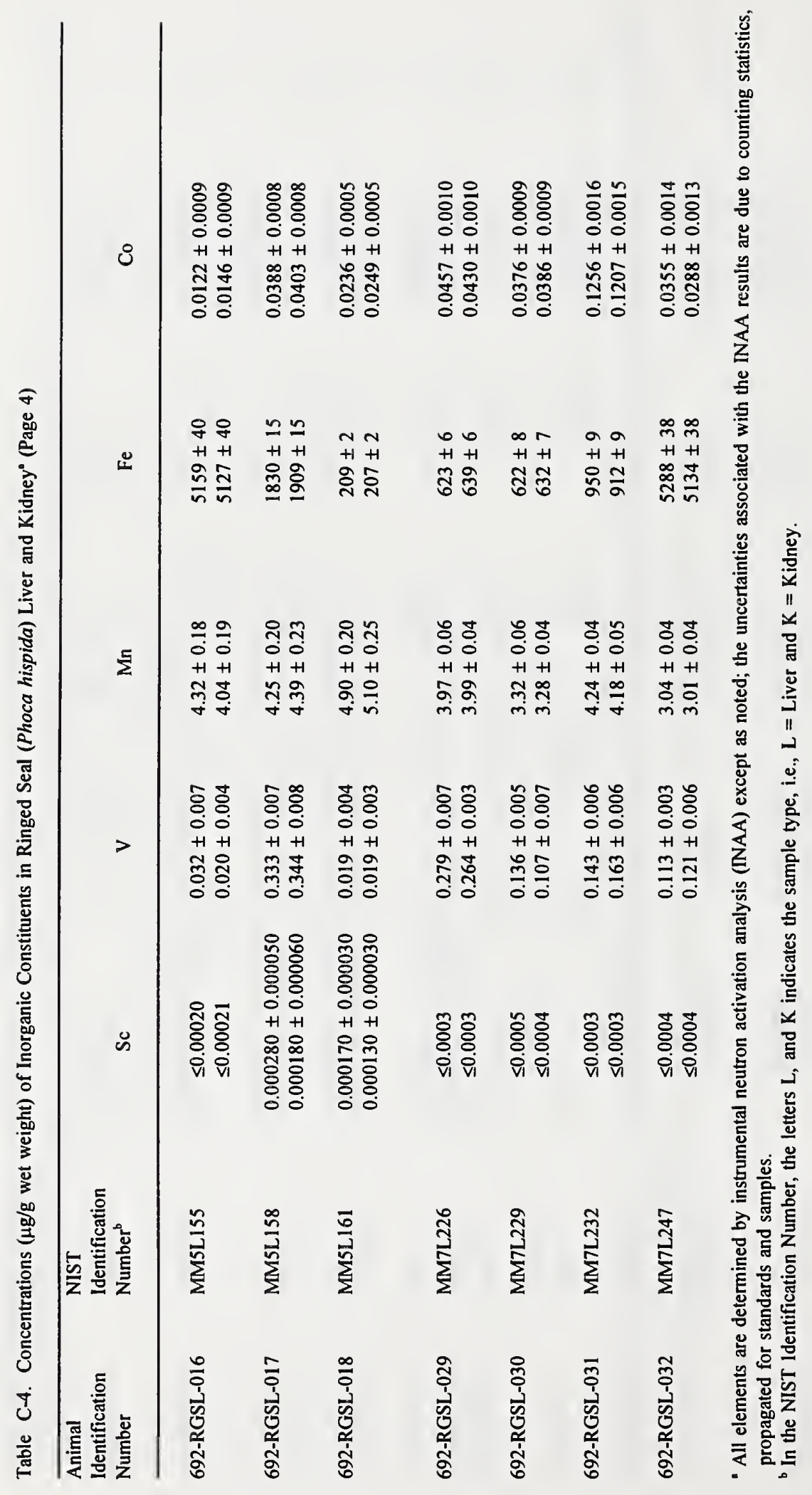




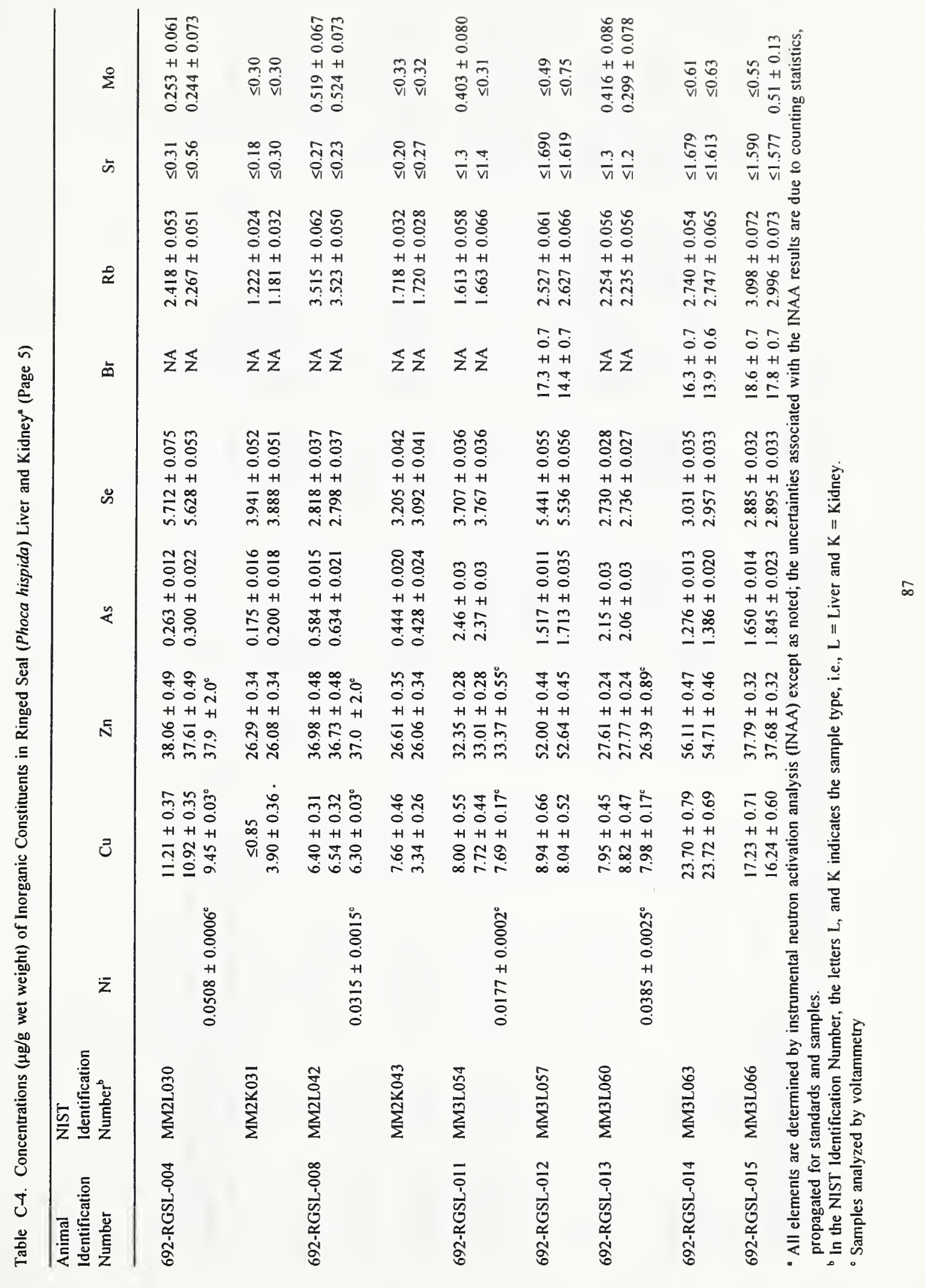




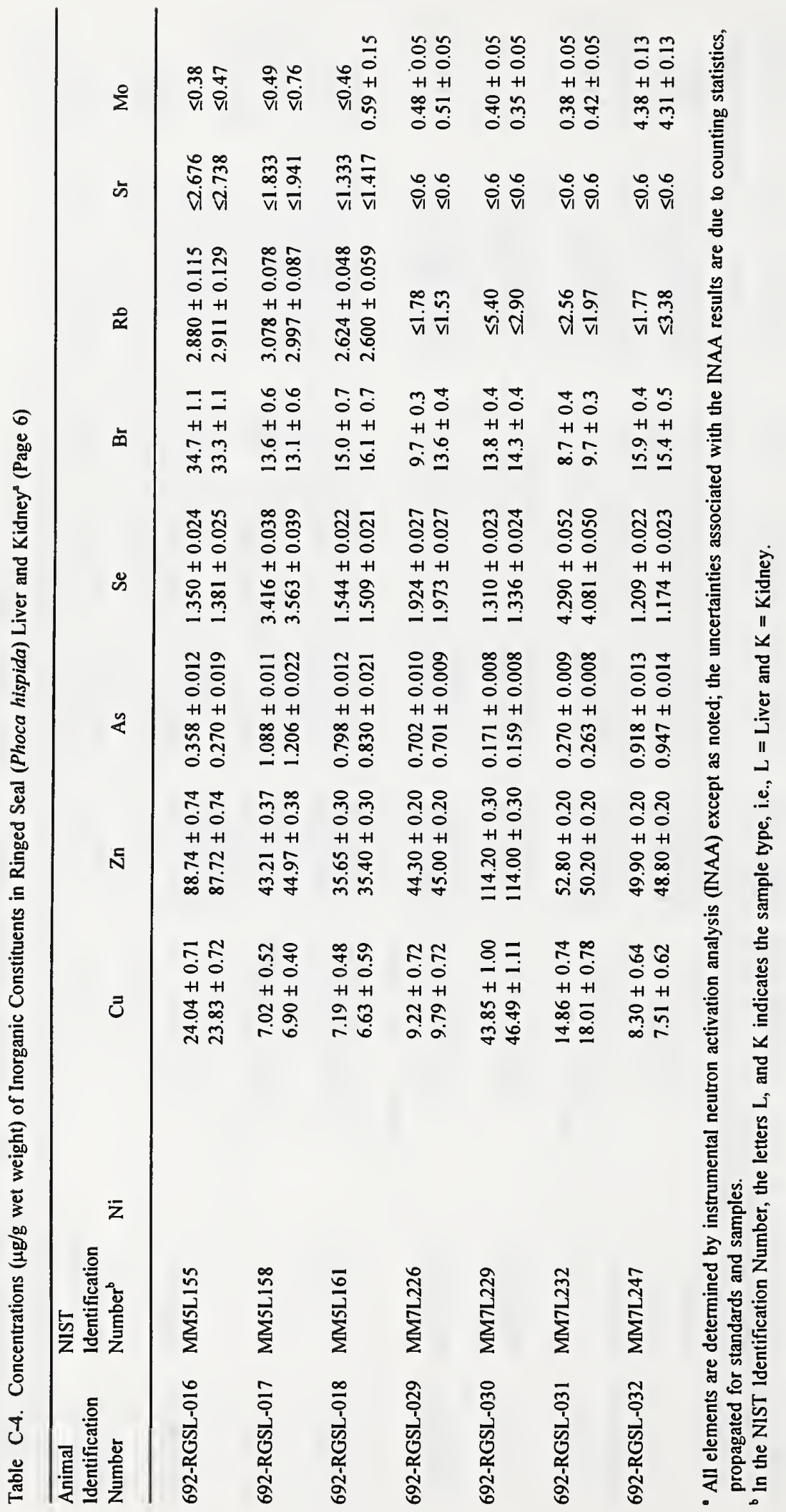




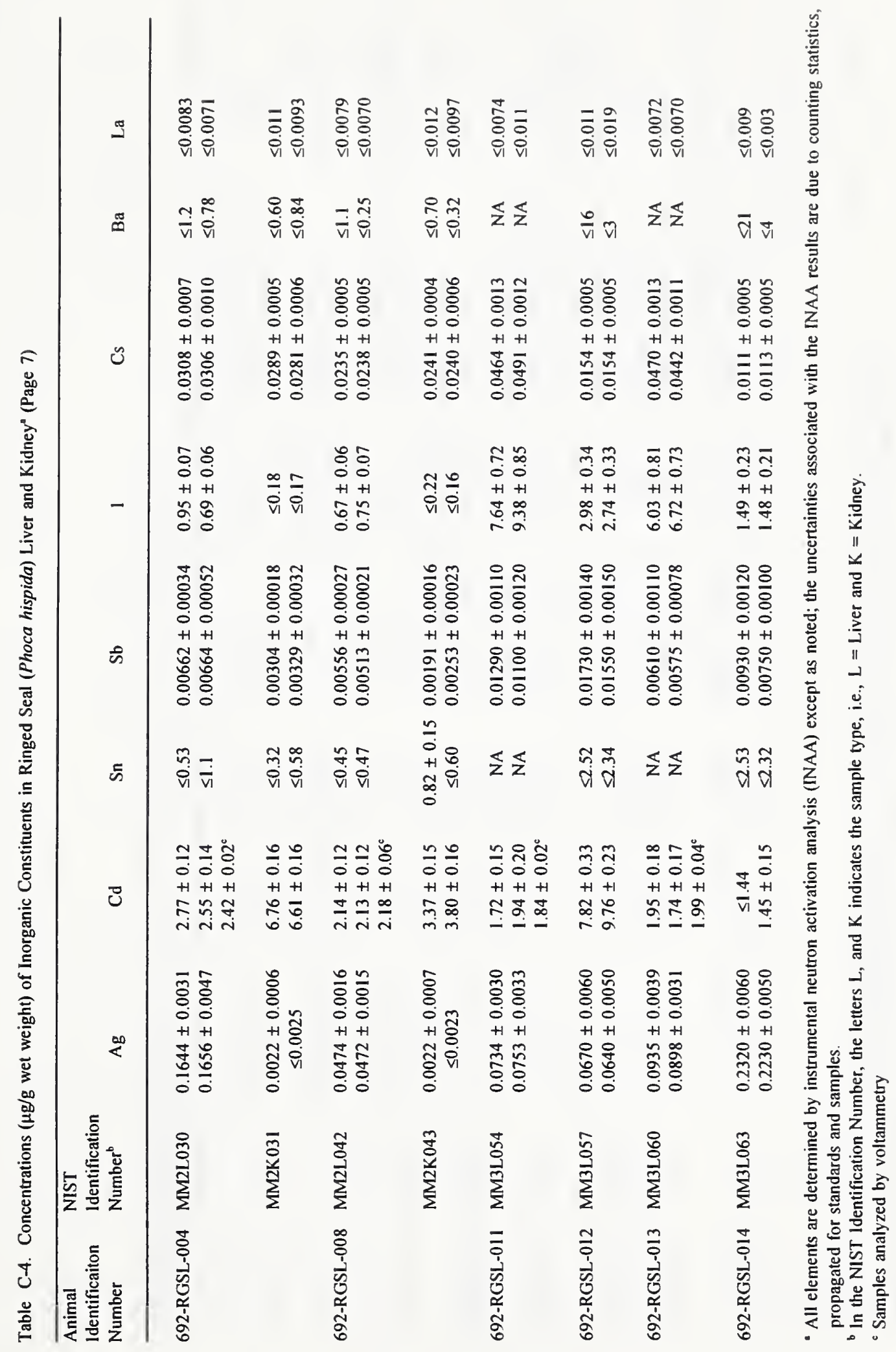




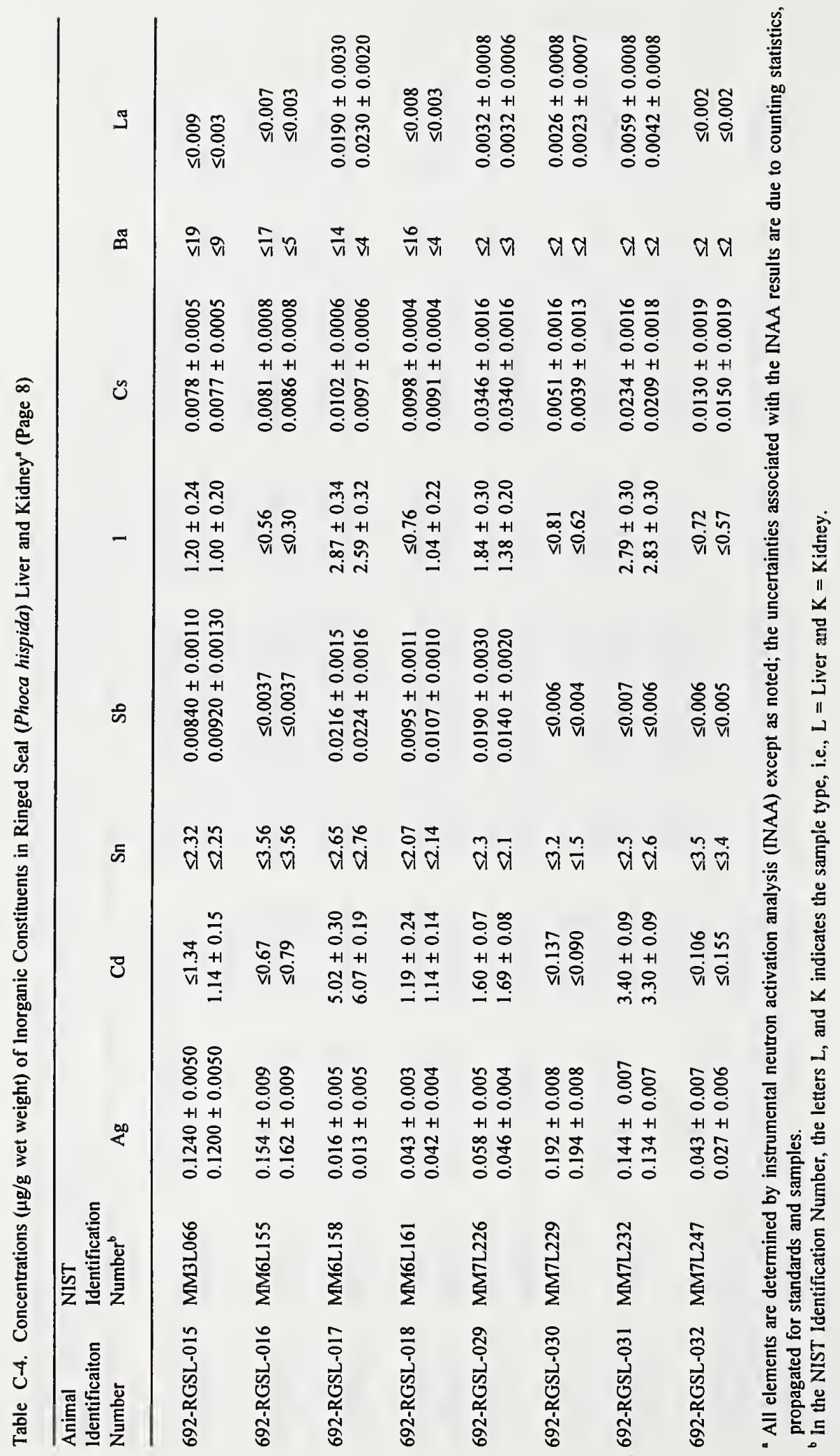




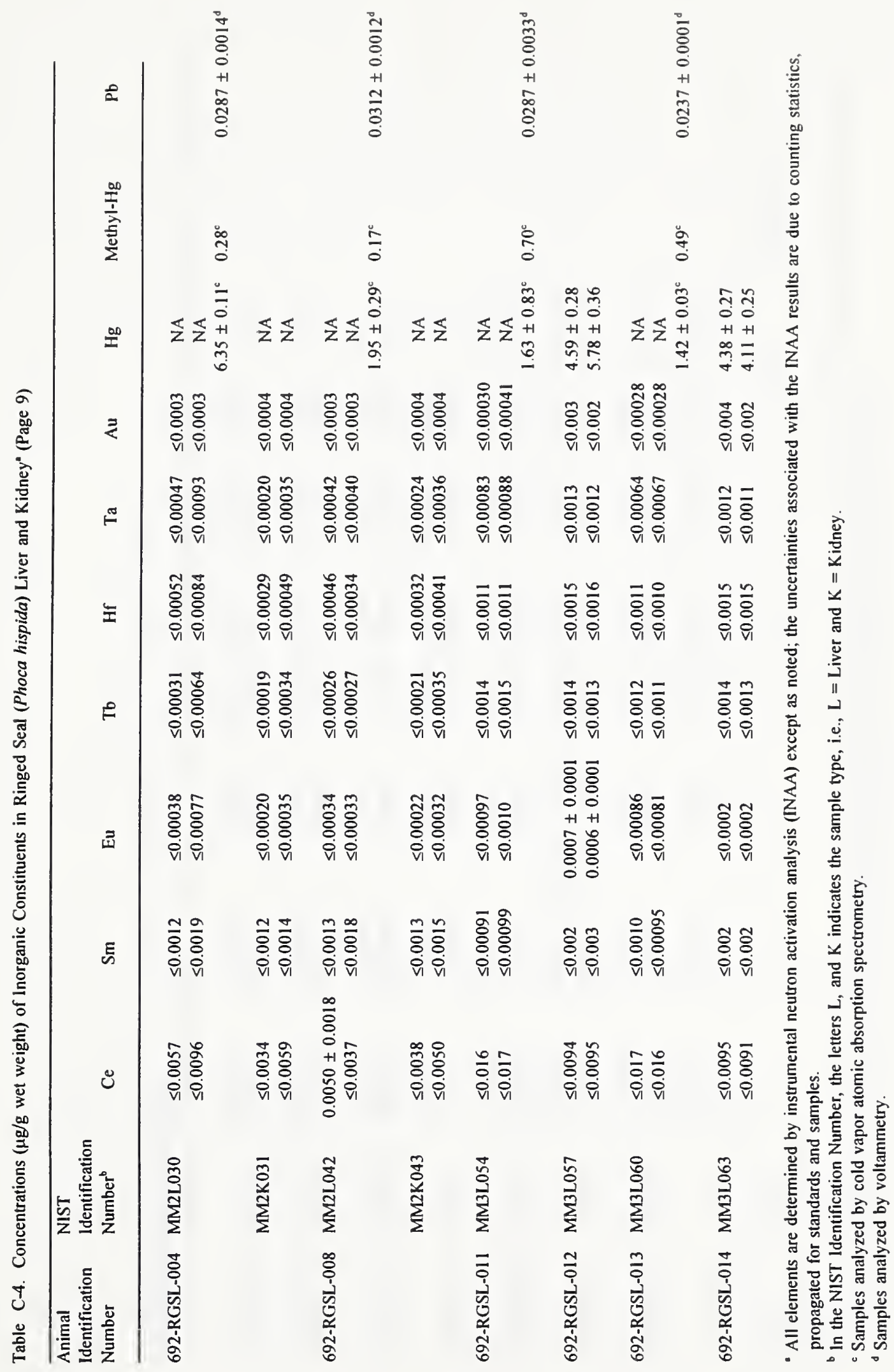




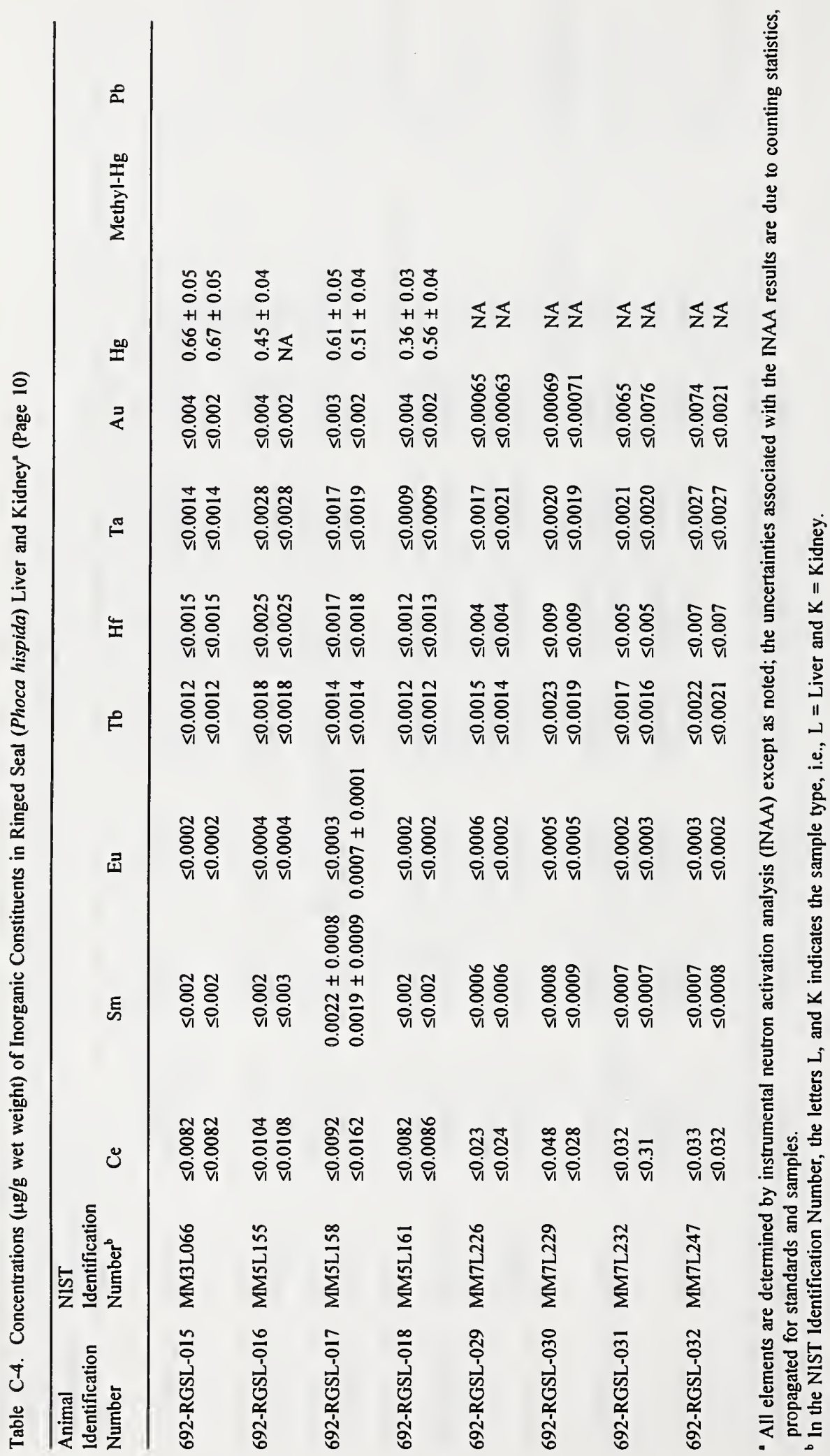




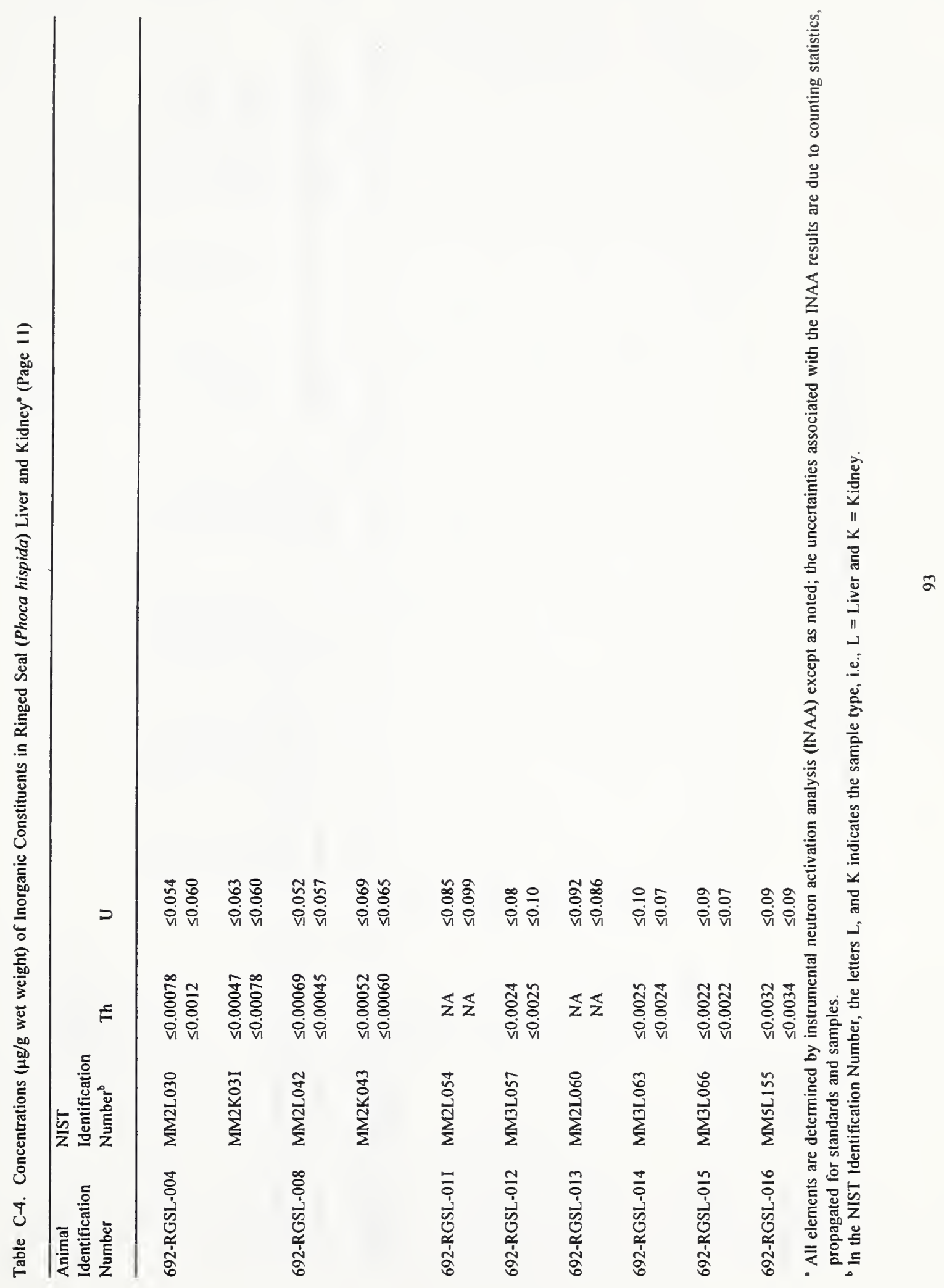




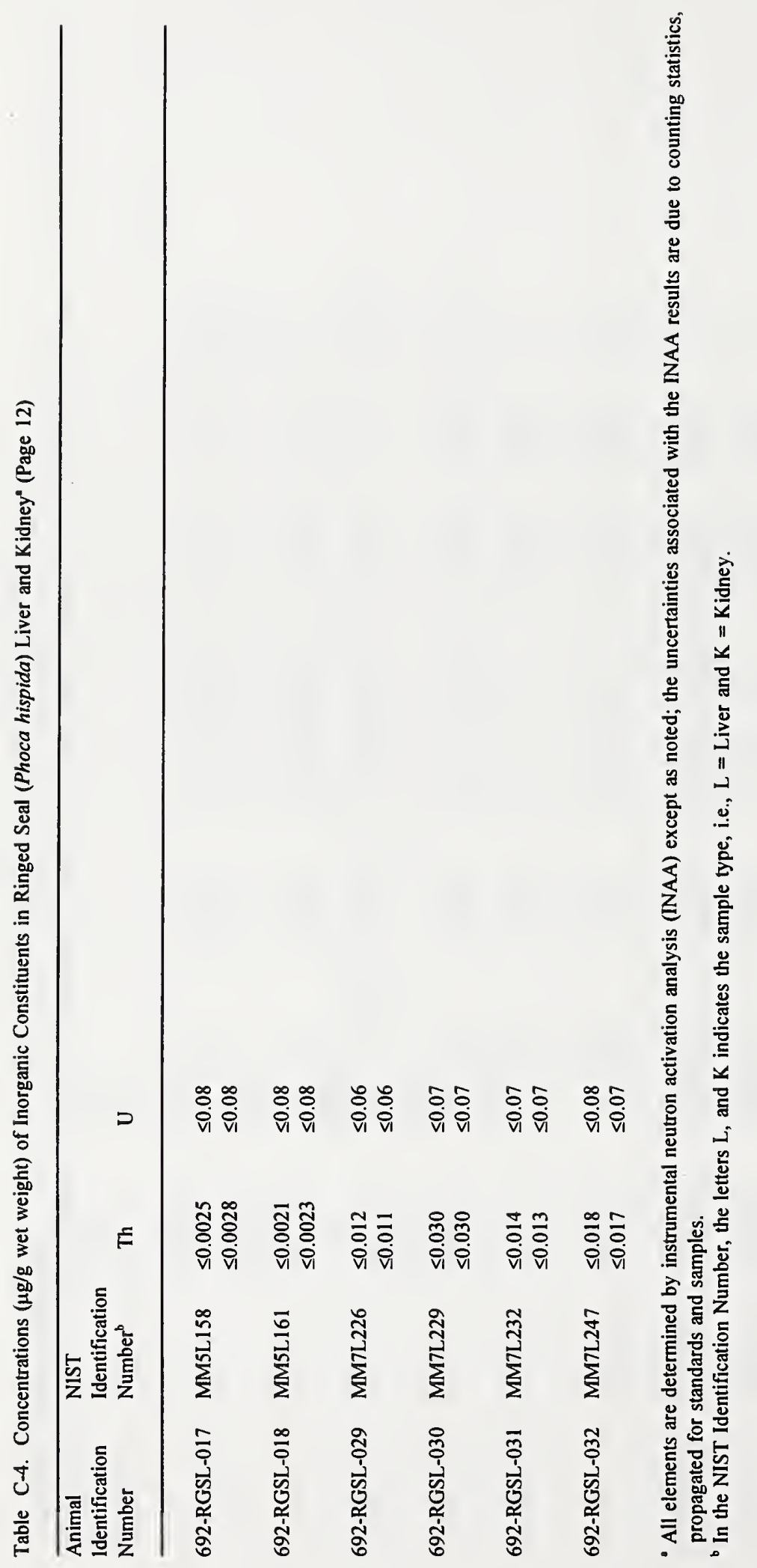




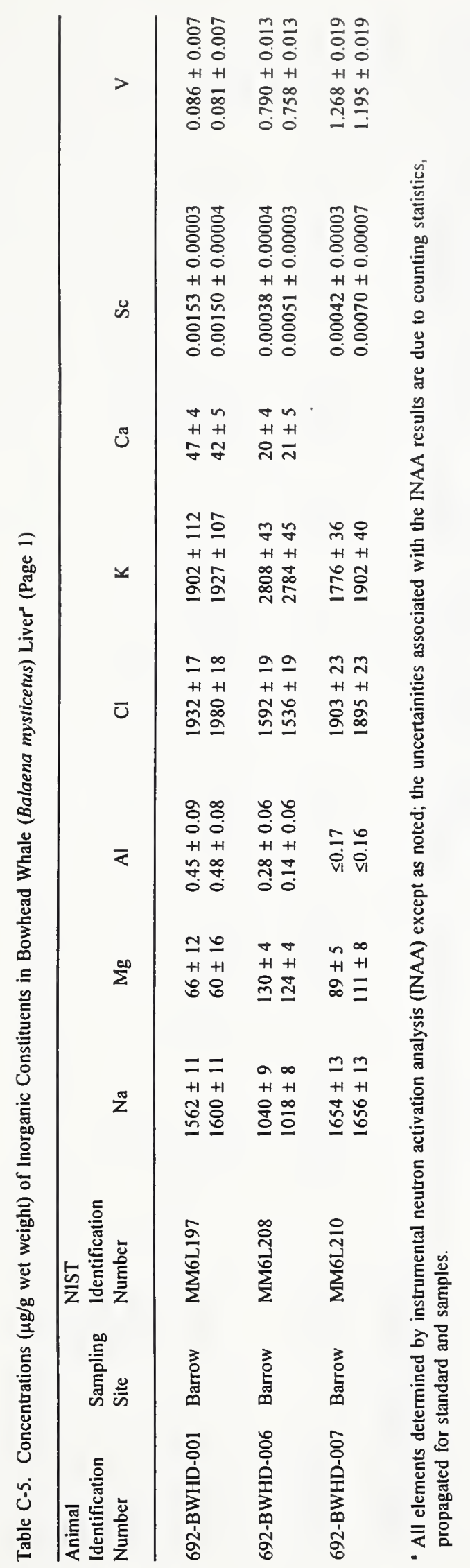




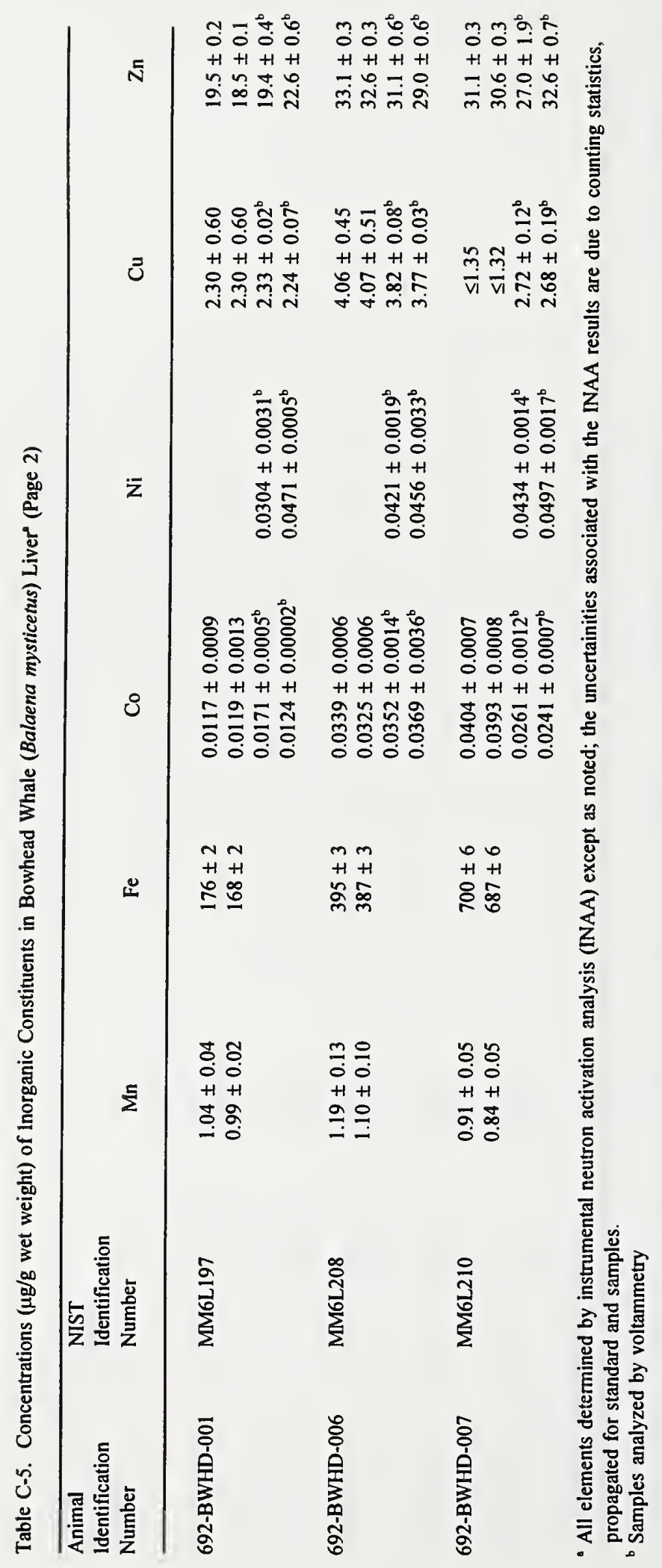




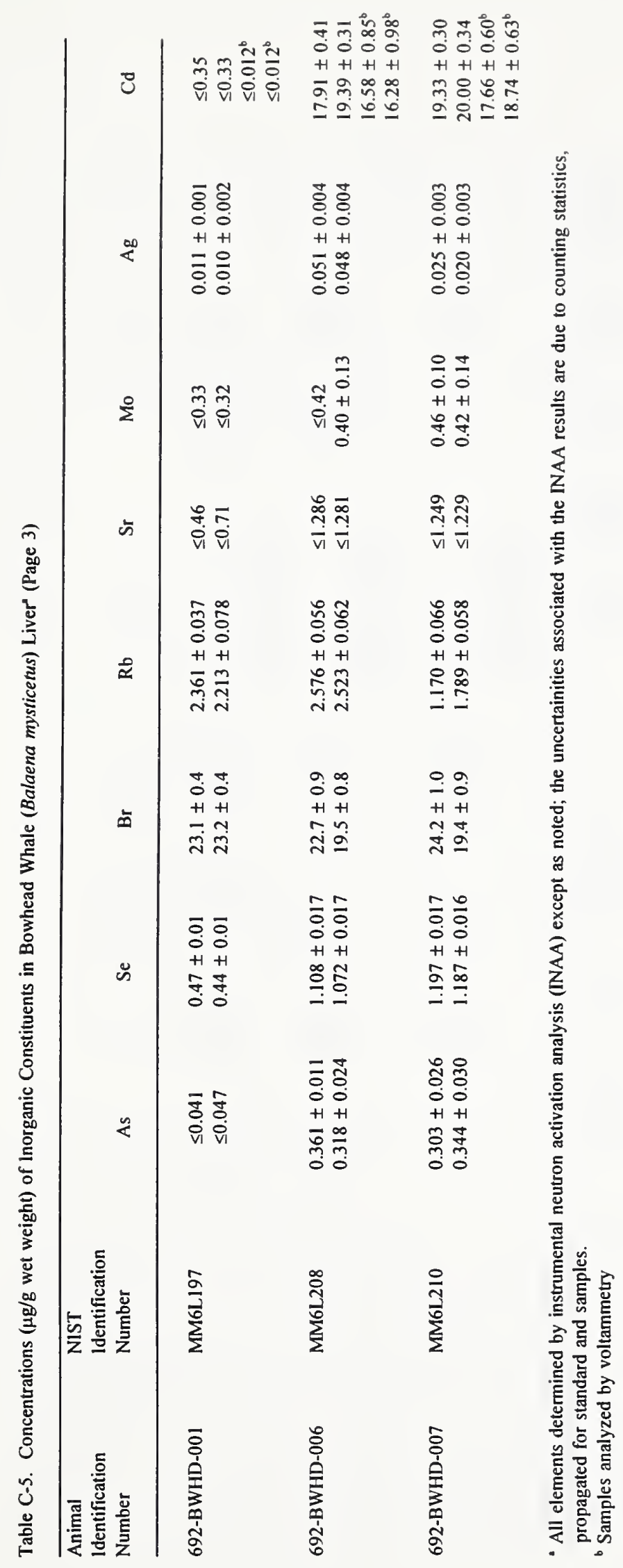




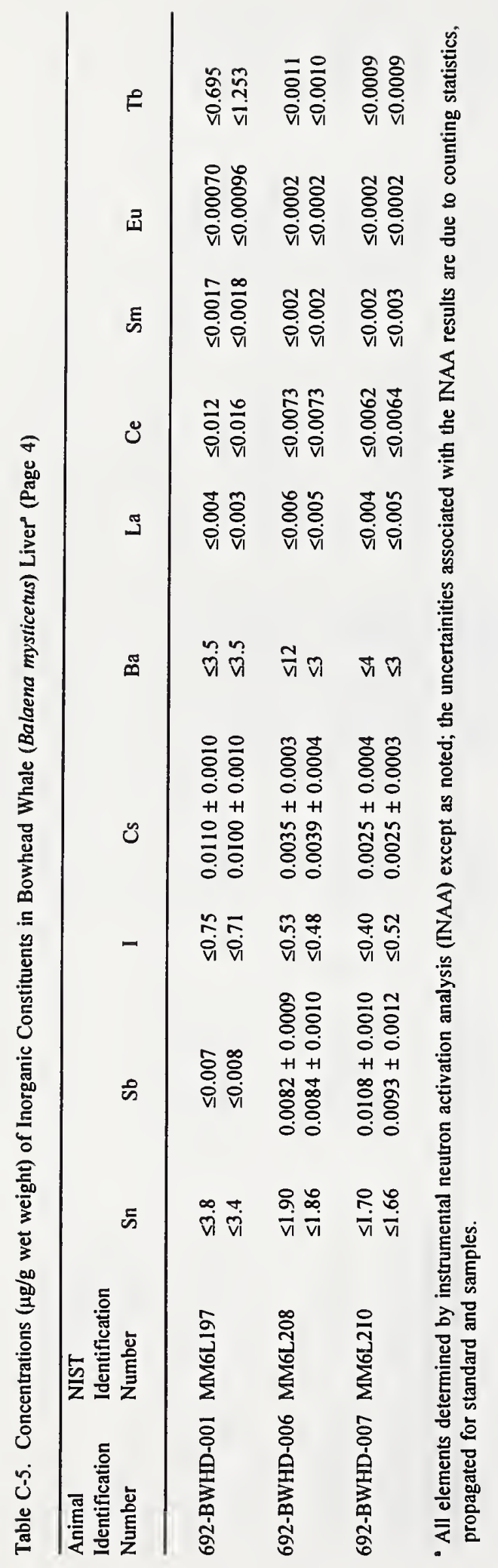

$\infty$ 


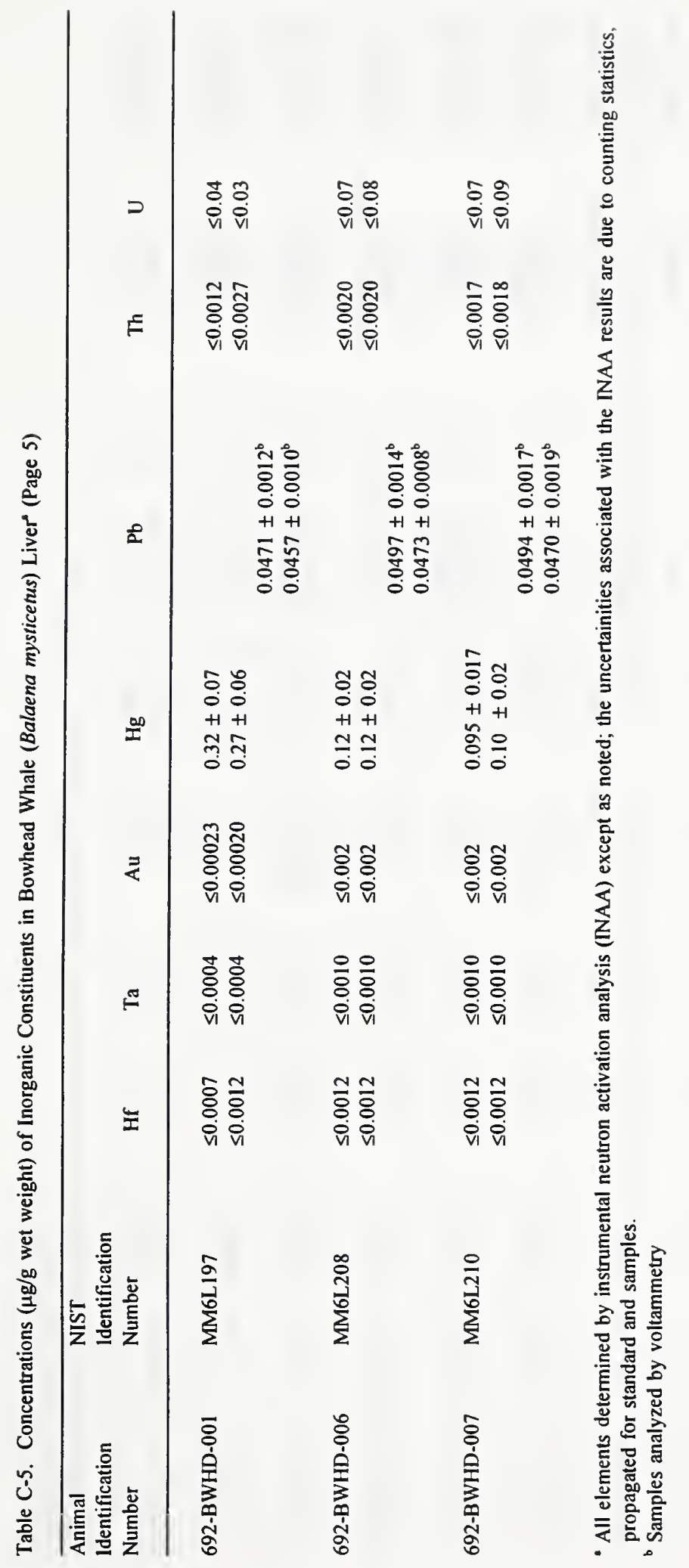




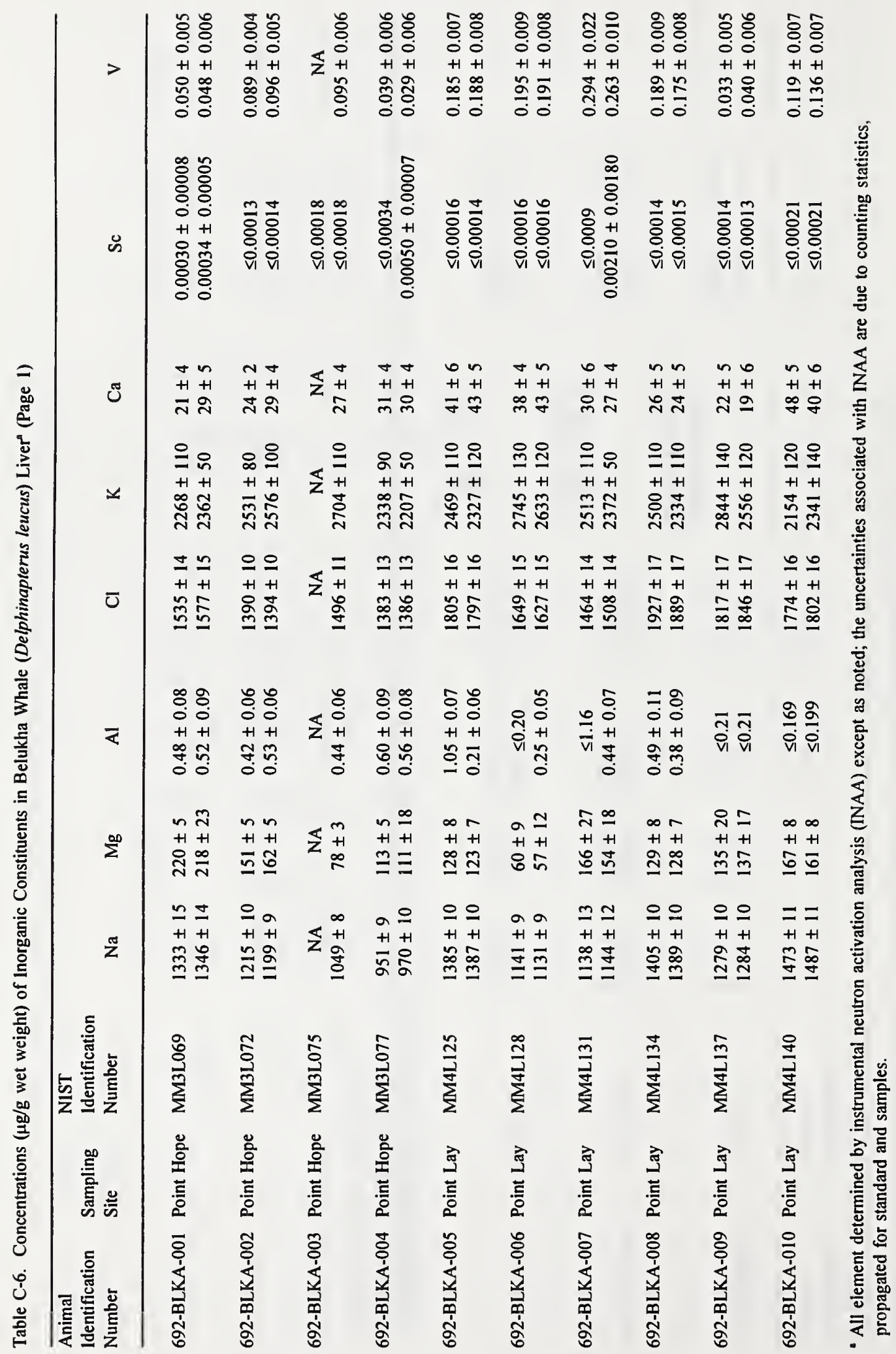




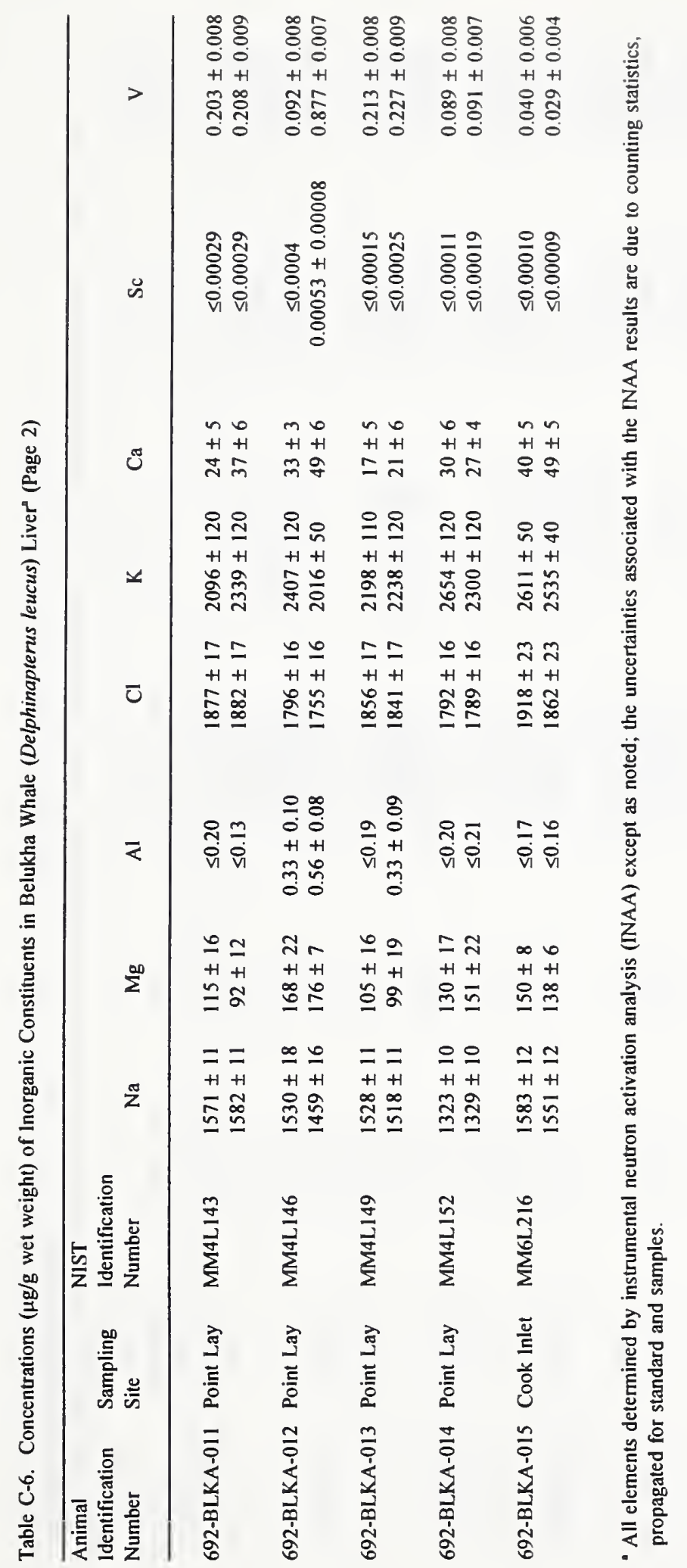




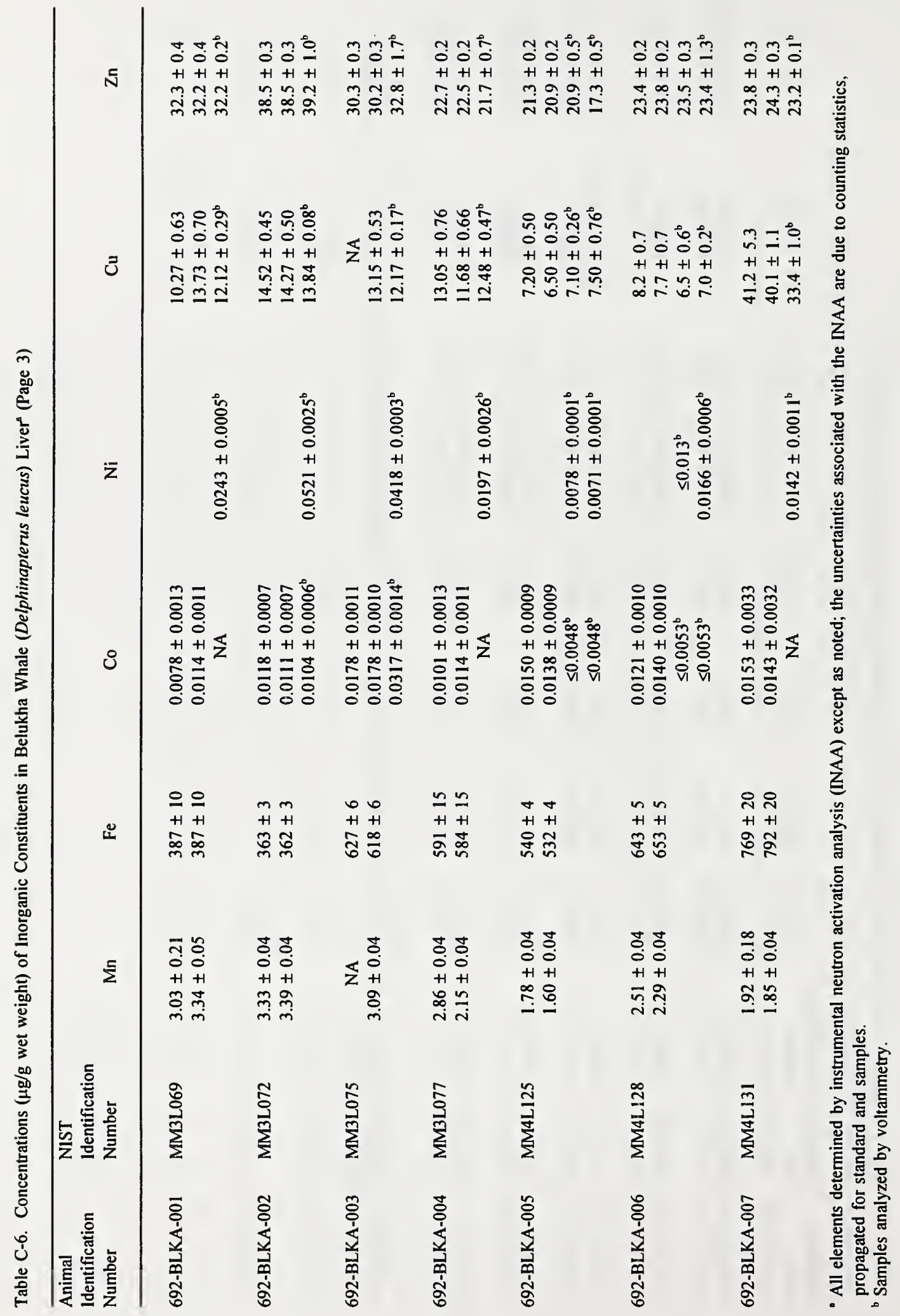




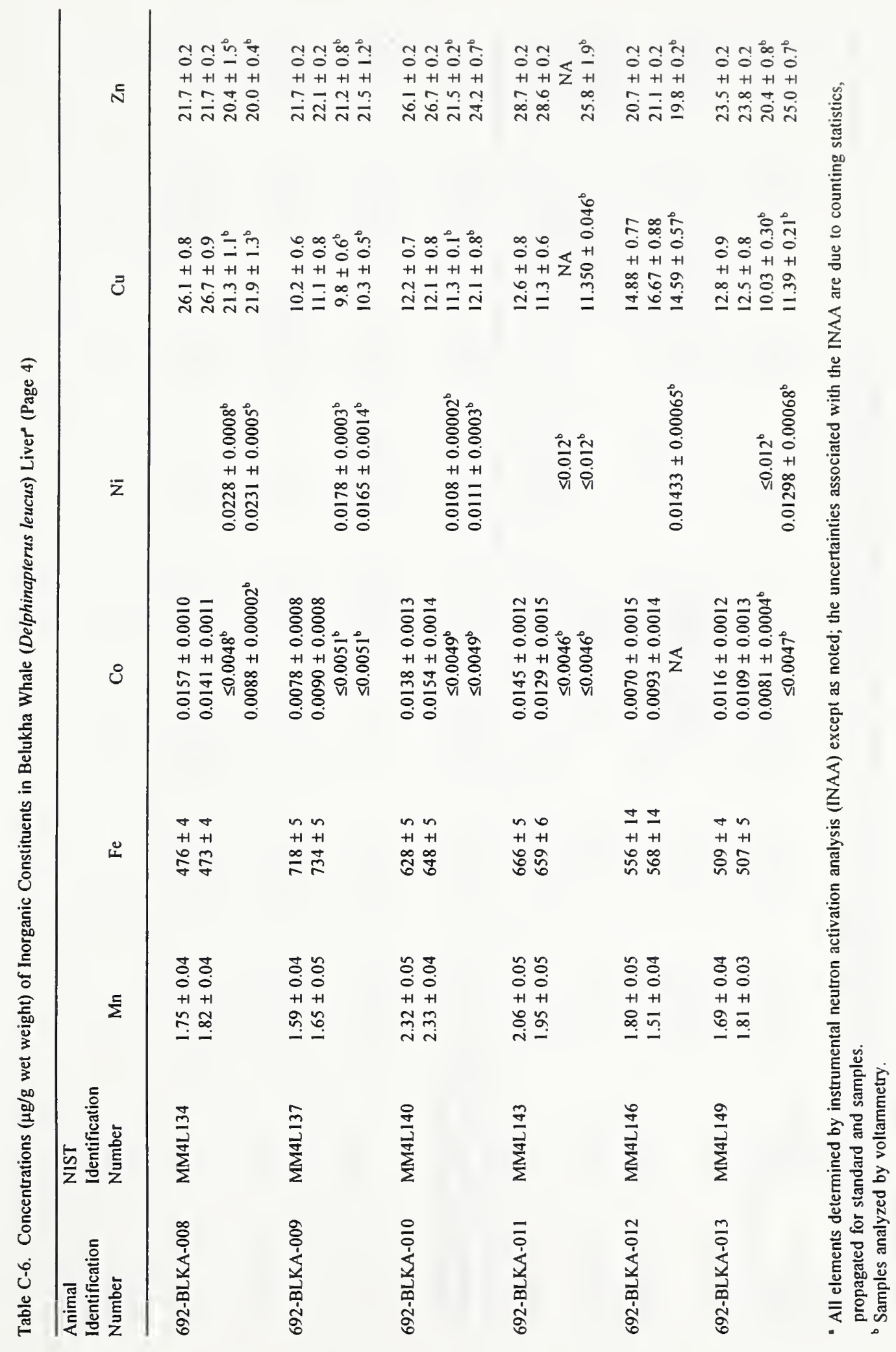




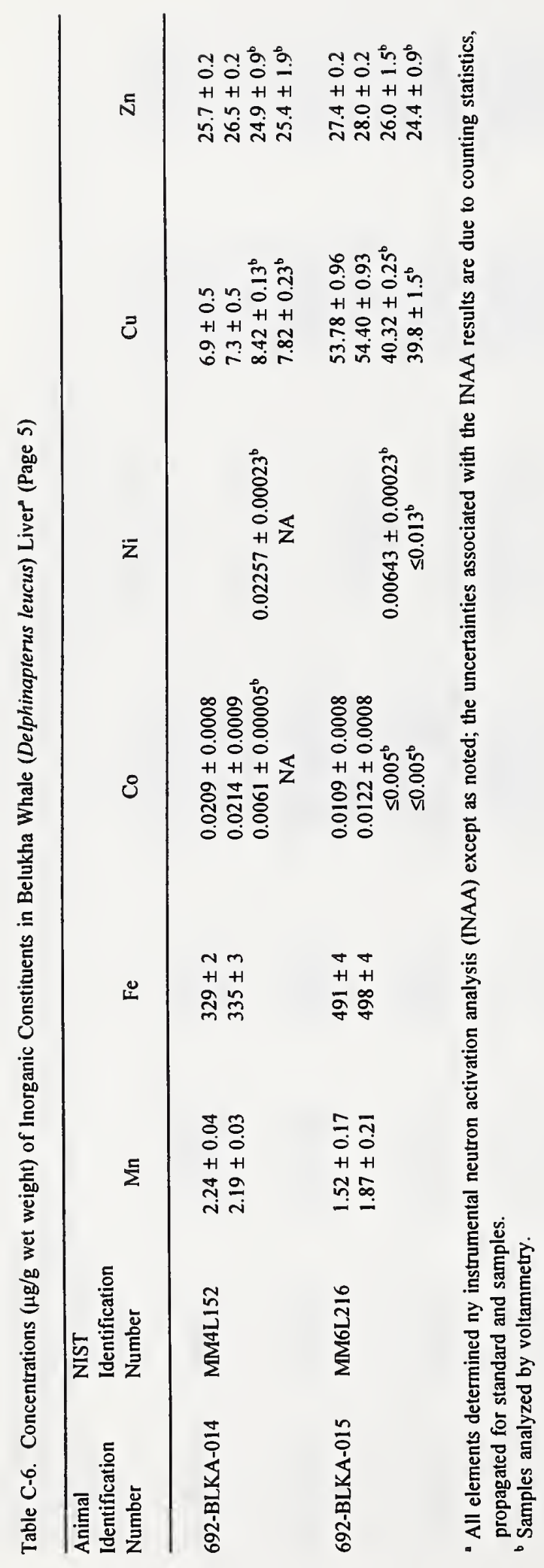




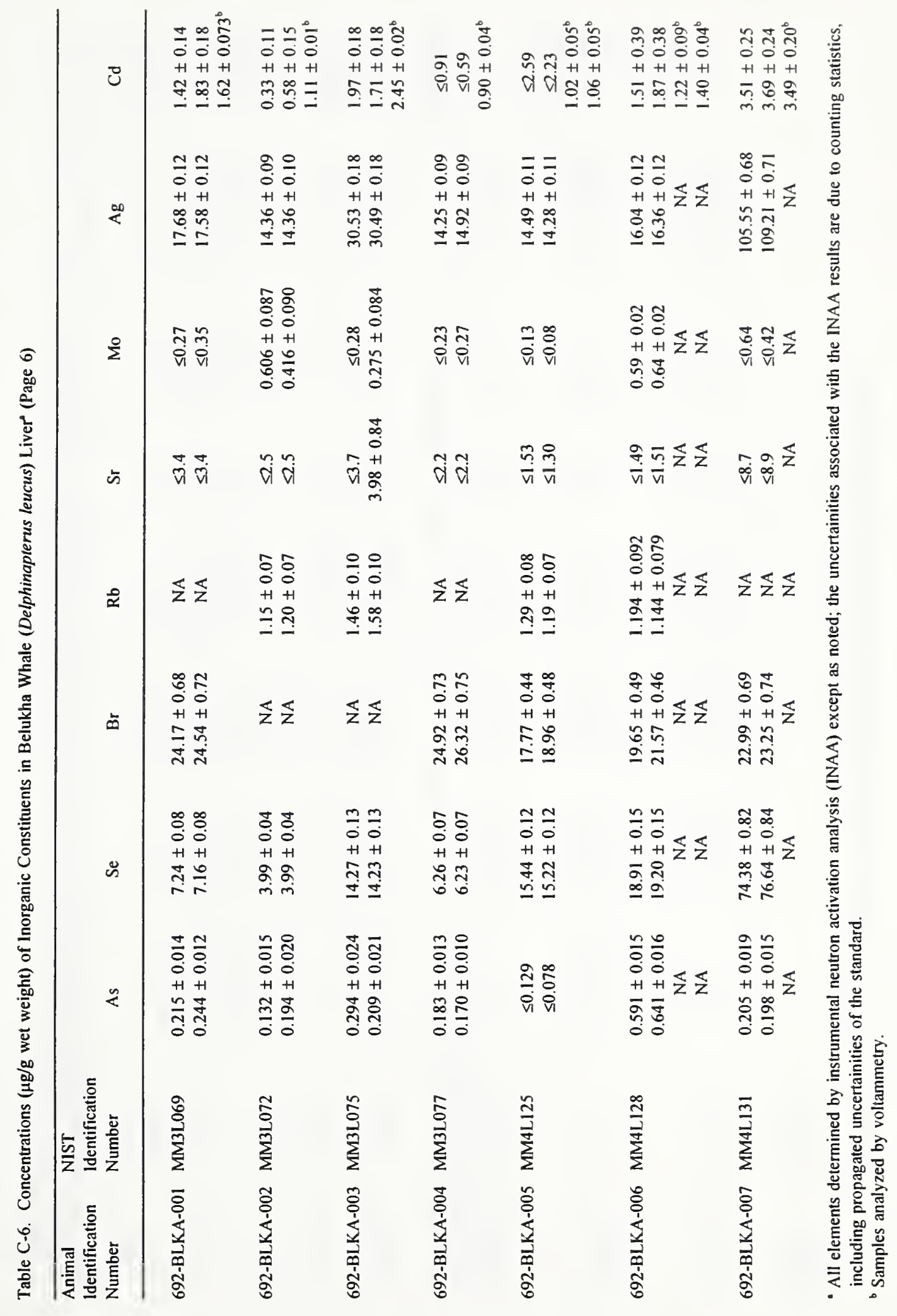




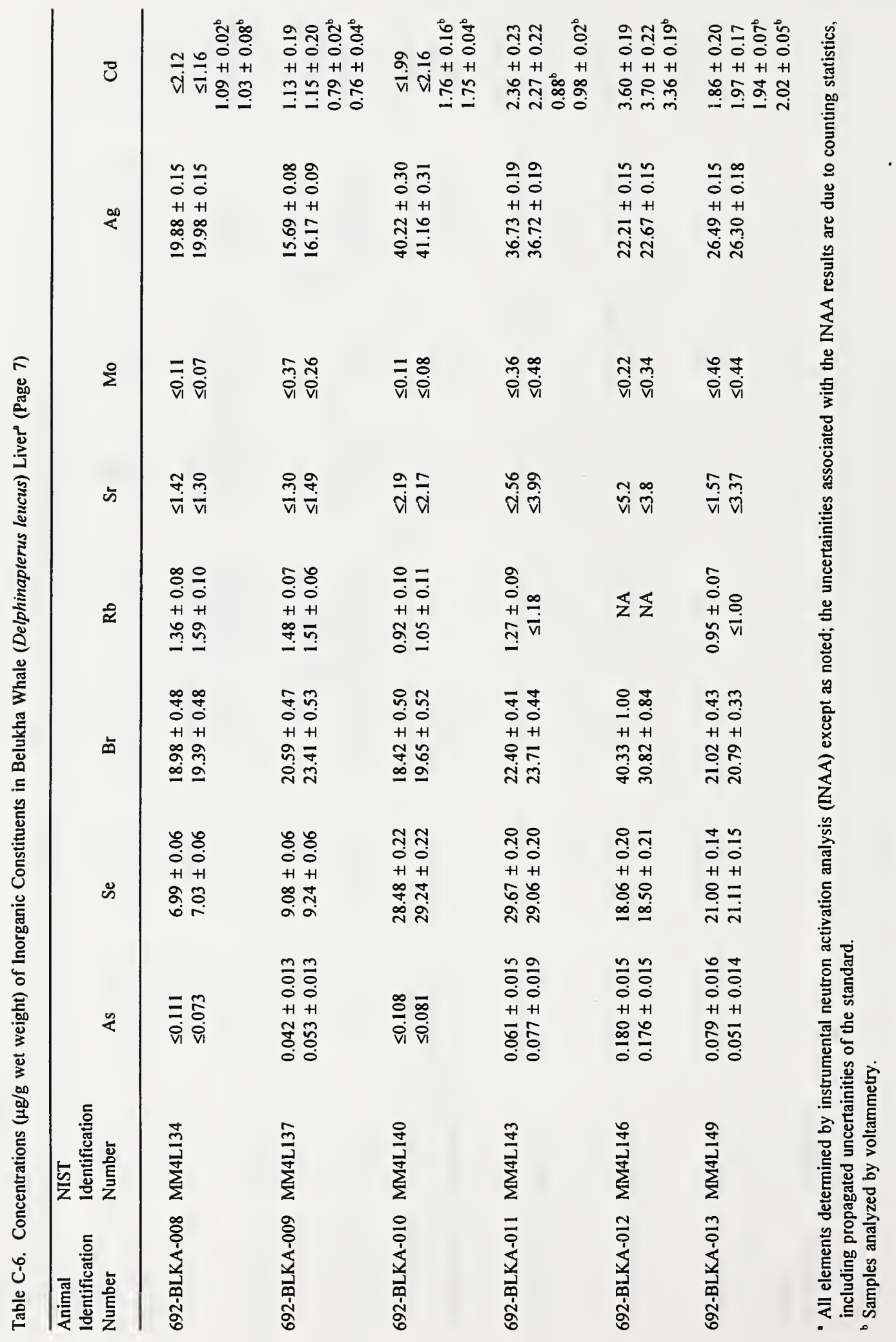




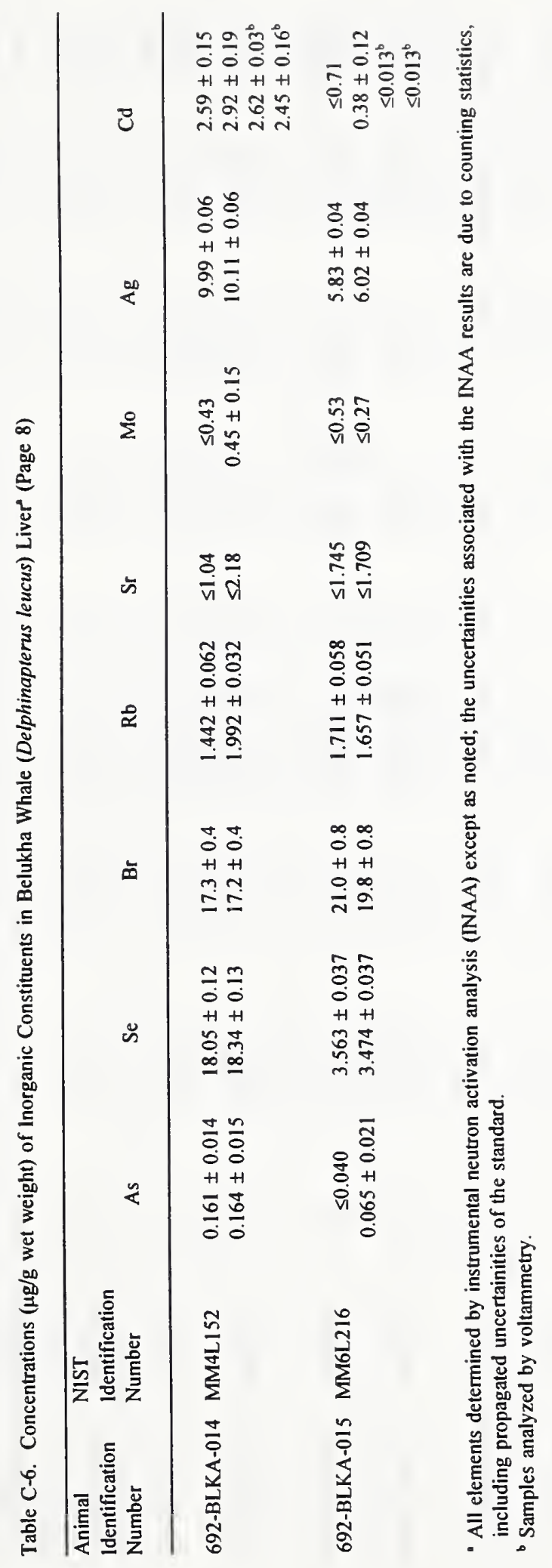




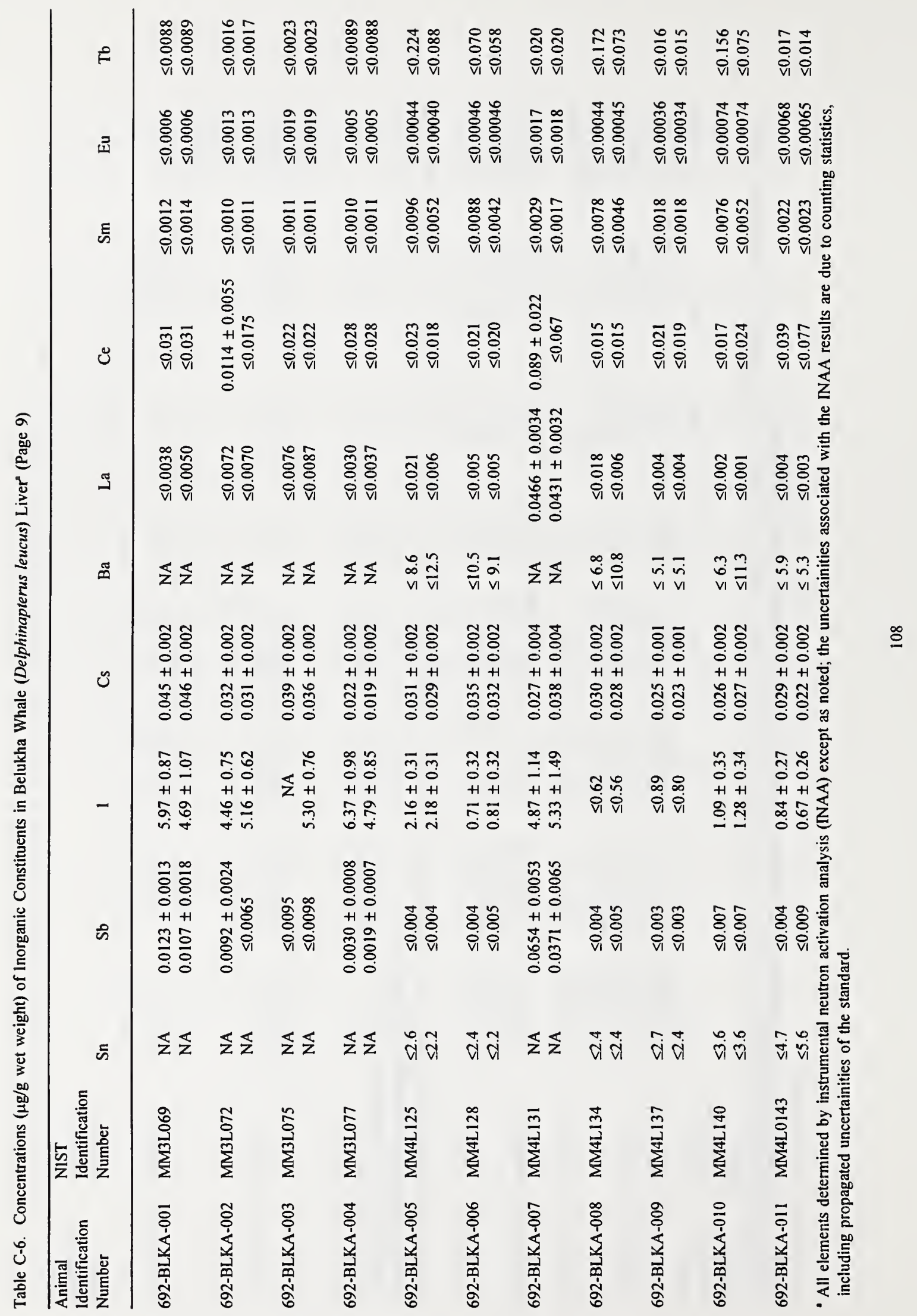




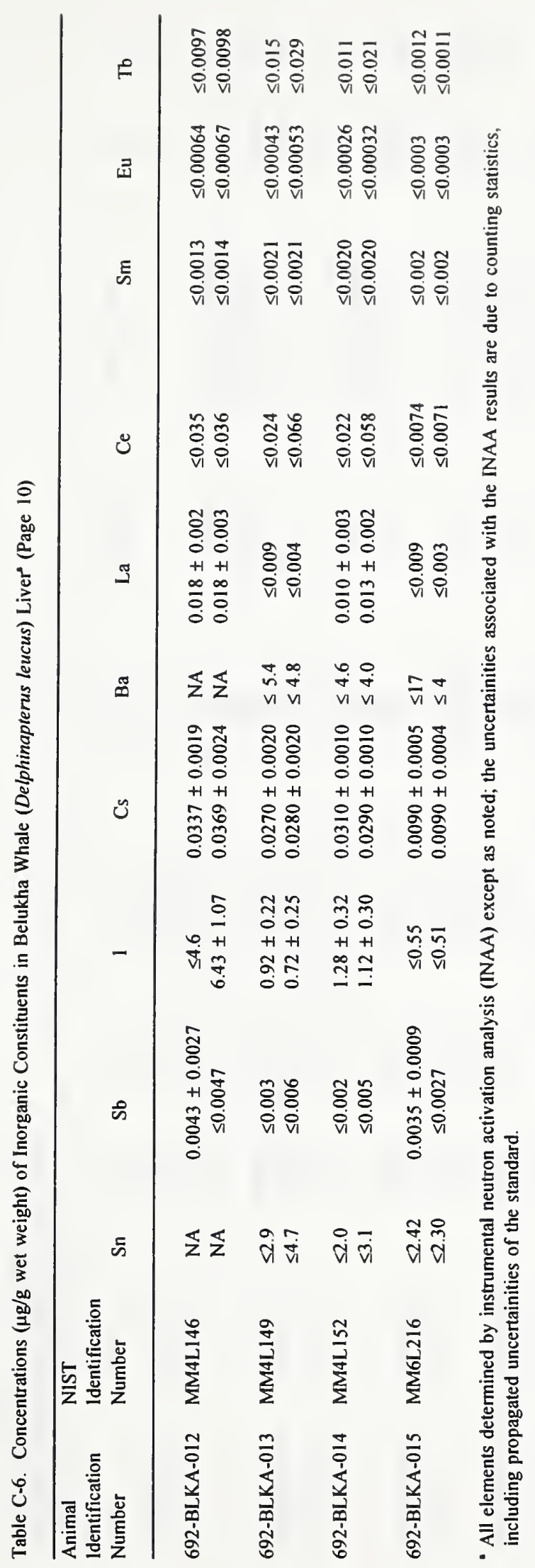




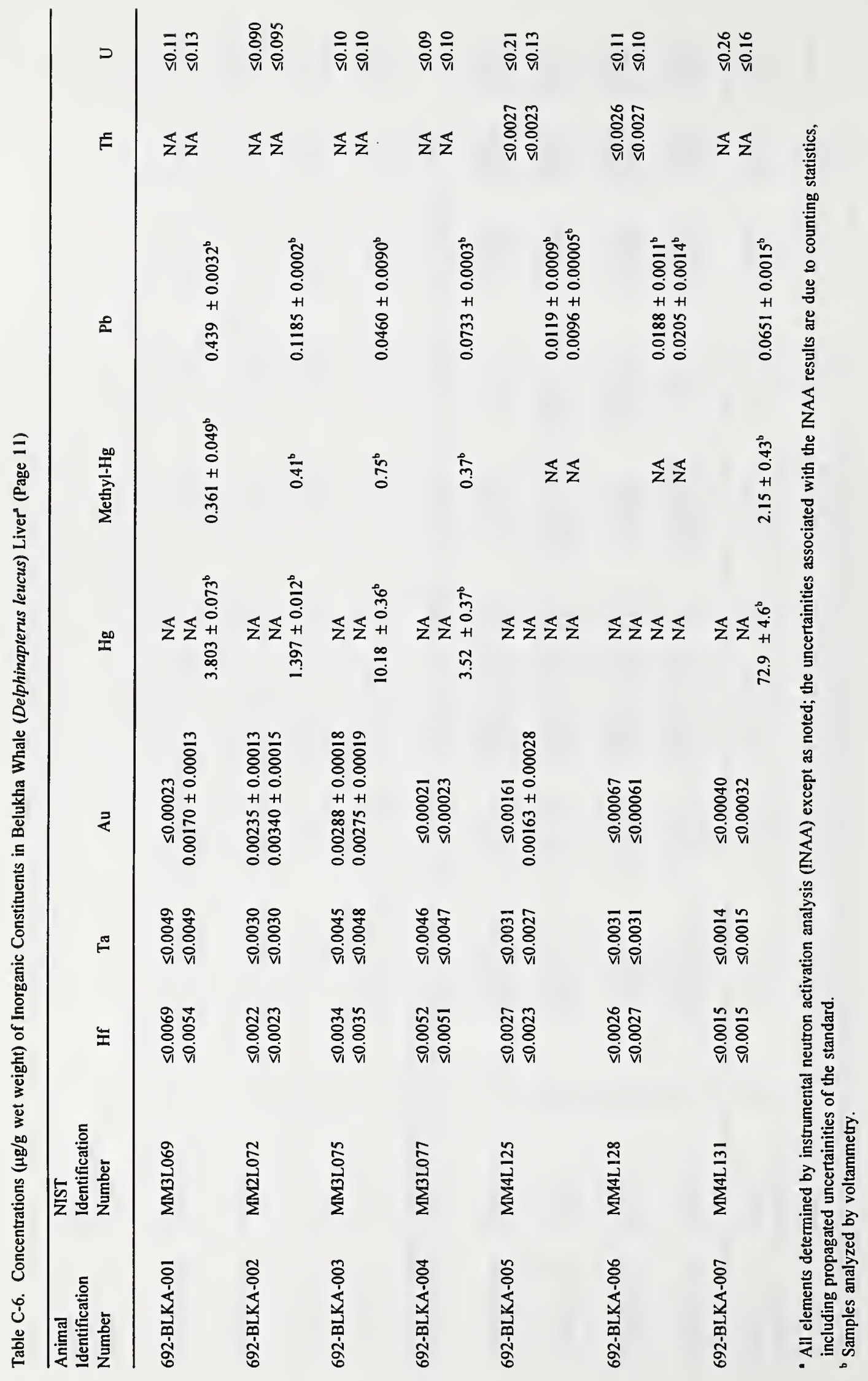




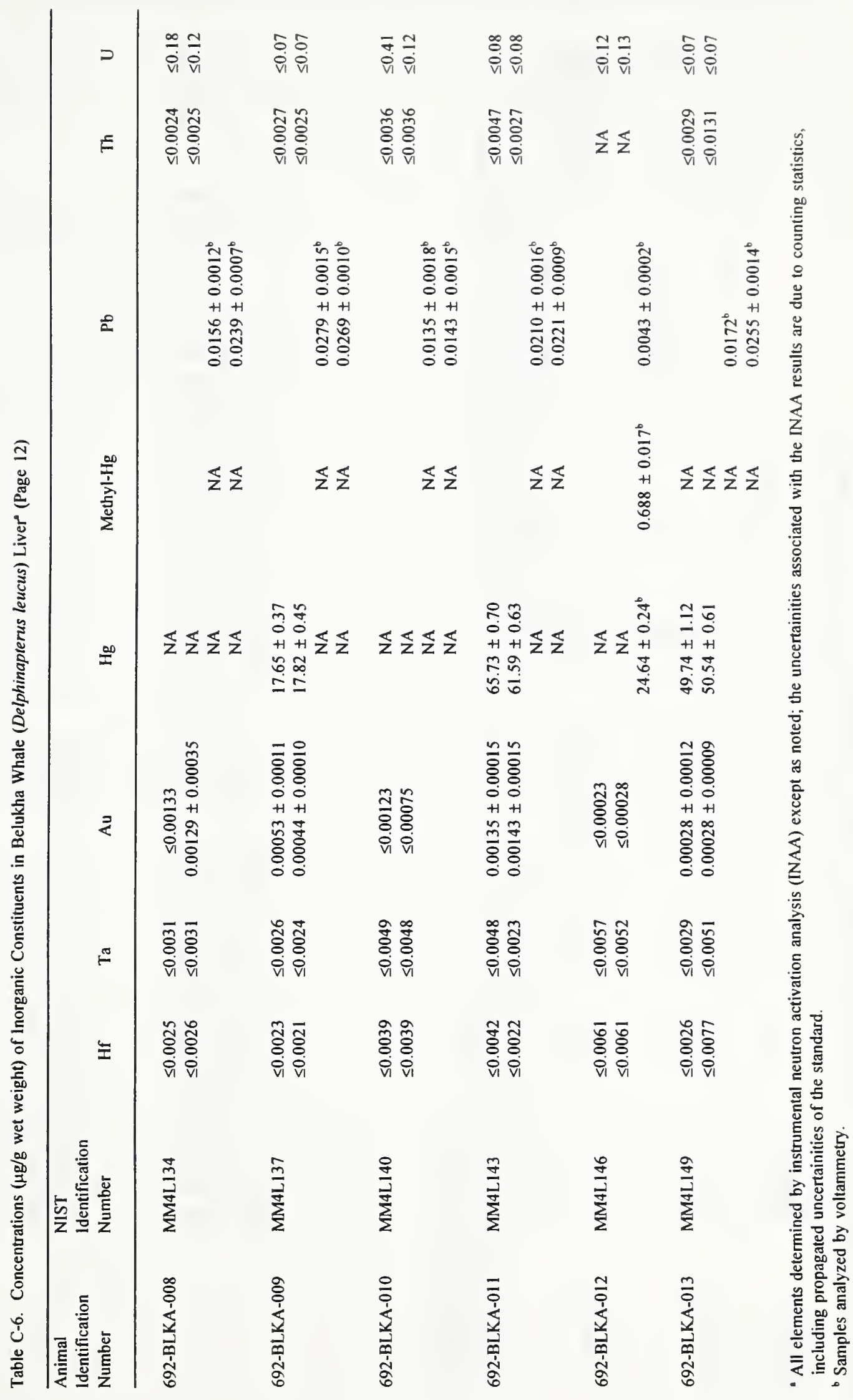




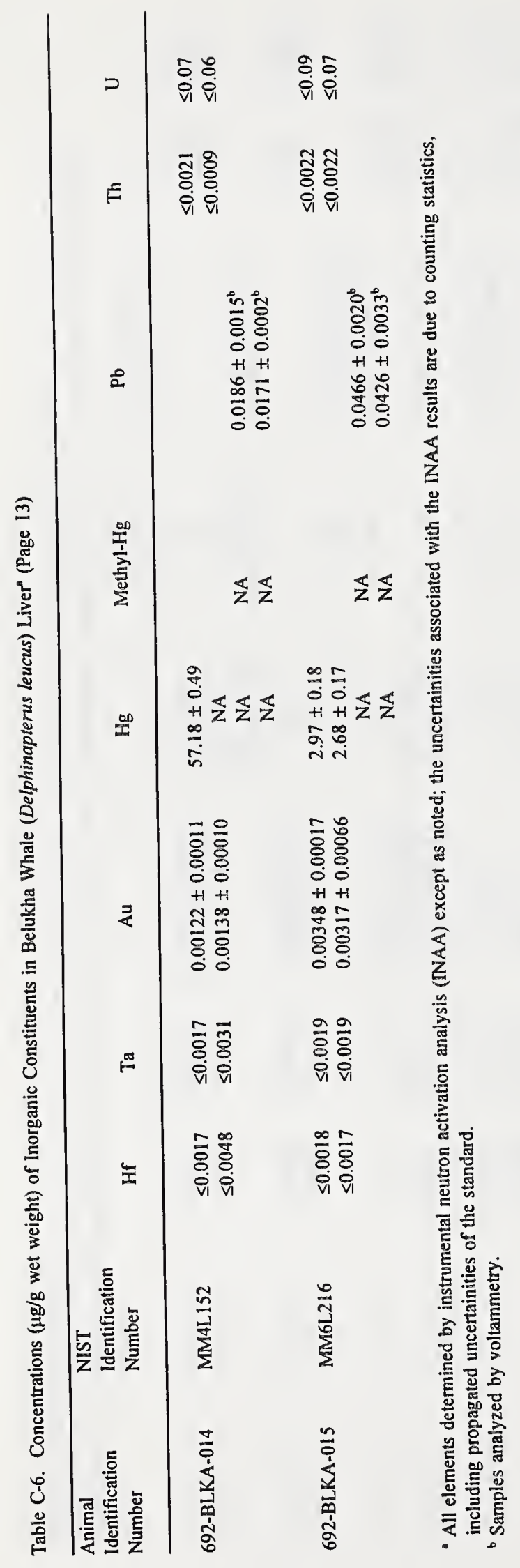


Table C-7. Conversion factors, ratio of dry weight to wet weight, for liver tissue analyzed by INAA.

\begin{tabular}{|c|c|c|}
\hline $\begin{array}{l}\text { Animal } \\
\text { Identification } \\
\text { Number }\end{array}$ & $\begin{array}{l}\text { NIST } \\
\text { Identification } \\
\text { Number }\end{array}$ & $\begin{array}{l}\text { Conversion Factor } \\
\text { (Ratio of dry to } \\
\text { wet weight) }\end{array}$ \\
\hline 692-BDSL-001 & MM3L051 & 0.2810 \\
\hline 692-BDSL-004 & MM7L223 & 0.2684 \\
\hline 692-BDSL-005 & MM7L250 & 0.2757 \\
\hline 692-SPSL-001 & MM5L164 & 0.2803 \\
\hline 692-RGSL-004 & MM2L030 & 0.2873 \\
\hline 692-RGSL-008 & MM2L042 & 0.2915 \\
\hline 692-RGSL-011 & MM3L054 & 0.2758 \\
\hline 692-RGSL-012 & MM3L057 & 0.3115 \\
\hline 692-RGSL-013 & MM3L060 & 0.2790 \\
\hline 692-RGSL-014 & MM3L063 & 0.2834 \\
\hline 692-RGSL-015 & MM3L066 & 0.2711 \\
\hline 692-RGSL-016 & MM5L155 & 0.2955 \\
\hline 692-RGSL-017 & MM5L 158 & 0.2811 \\
\hline 692-RGSL-018 & MM5L161 & 0.2743 \\
\hline 692-RGSL-029 & MM7L226 & 0.2996 \\
\hline 692-RGSL-030 & MM7L229 & 0.2795 \\
\hline 692-RGSL-031 & MM7L232 & 0.2949 \\
\hline 692-RGSL-032 & MM7L247 & 0.2996 \\
\hline 692-BWHD-001 & MM6L197 & 0.2412 \\
\hline 692-BWHD-006 & MM6L208 & 0.2733 \\
\hline 692-BWHD-007 & MM6L210 & 0.2406 \\
\hline 692-BLKA-001 & MM3L069 & 0.2438 \\
\hline 692-BLKA-002 & MM3L072 & 0.2494 \\
\hline 692-BLKA-003 & MM3L075 & 0.2804 \\
\hline 692-BLKA-004 & MM3L077 & 0.2628 \\
\hline 692-BLKA-005 & MM4L125 & 0.2403 \\
\hline 692-BLKA-006 & MM4L128 & 0.2648 \\
\hline 692-BLKA-007 & MM4L131 & 0.2532 \\
\hline 692-BLKA-008 & MM4L134 & 0.2397 \\
\hline 692-BLKA-009 & MM4L137 & 0.2578 \\
\hline 692-BLKA-010 & MM4L 140 & 0.2474 \\
\hline 692-BLKA-011 & MM4L143 & 0.2361 \\
\hline 692-BLKA-012 & MM4L146 & 0.2416 \\
\hline 692-BLKA-013 & MM4L149 & 0.2513 \\
\hline 692-BLKA-014 & MM4L152 & 0.2506 \\
\hline 692-BLKA-015 & MM6L216 & 0.2562 \\
\hline
\end{tabular}




\section{APPENDIX D}

QUALITY CONTROL FOR INORGANIC ANALYSIS:

RESULTS OF INAA OF CONTROL MATERIALS 
Table D-1. Quality assurance: results of instrumental neutron activation analysis (INAA) of control materials included with the analysis of marine mammal liver tissues concentrations in $\mu \mathrm{g} / \mathrm{g}$. The uncertainties represent the standard deviation of the average value.

\begin{tabular}{|c|c|c|c|c|}
\hline \multirow[b]{2}{*}{ ELEMENT } & \multicolumn{2}{|c|}{ NIST SRM 1577a, Bovine Liver } & \multicolumn{2}{|c|}{ QA Pilot Whale Liver Homogenate } \\
\hline & AVERAGE & CERTIFIED & AVERAGE & WISE ET AL., 1993 \\
\hline $\mathrm{Na}$ & $2290 \pm 63.5$ & $2430 \pm 130$ & $1279 \pm 5$ & 1260 \\
\hline $\mathrm{Mg}$ & $637 \pm 33$ & $600 \pm 15$ & $125 \pm 3$ & 138 \\
\hline $\mathrm{Al}$ & $1.14 \pm 0.26$ & $(2)^{n}$ & $N A^{b}$ & inhomogeneous \\
\hline $\mathrm{Cl}$ & $2639 \pm 86$ & $2800 \pm 100$ & $1745 \pm 16$ & 1730 \\
\hline $\mathrm{K}$ & $9827 \pm 371$ & $9960 \pm 70$ & $2712 \pm 30$ & 2640 \\
\hline $\mathrm{Ca}$ & $128 \pm 21$ & $120 \pm 7$ & $40 \pm 5$ & 46 \\
\hline Sc & $\leq 0.001$ & $\mathrm{NC}^{\mathrm{c}}$ & $\leq 0.001$ & $\leq 0.0008$ \\
\hline $\mathrm{V}$ & $0.085 \pm 0.014$ & $\mathrm{NC}$ & $\leq 0.02$ & $\leq 0.02$ \\
\hline $\mathrm{Mn}$ & $9.48 \pm 0.41$ & $9.9 \pm 0.8$ & $2.70 \pm 0.04$ & 2.81 \\
\hline $\mathrm{Fe}$ & $186 \pm 5$ & $194 \pm 20$ & $448 \pm 5$ & 438 \\
\hline Co & $0.228 \pm 0.010$ & $0.21 \pm 0.05$ & $0.0144 \pm 0.0006$ & 0.014 \\
\hline $\mathrm{Cu}$ & $151 \pm 5$ & $158 \pm 7$ & $3.10 \pm 0.08$ & 2.96 \\
\hline $\mathrm{Zn}$ & $121 \pm 2$ & $123 \pm 8$ & $32.5 \pm 1.0$ & 32.2 \\
\hline As & $\leq 0.06$ & $0.047 \pm 0.006$ & $0.512 \pm 0.024$ & 0.529 \\
\hline $\mathrm{Se}$ & $0.67 \pm 0.04$ & $0.71 \pm 0.07$ & $11.4 \pm 2$ & 11.0 \\
\hline $\mathrm{Br}$ & NA & (9) & $13.7 \pm 0.6$ & NA \\
\hline $\mathrm{Rb}$ & $12.3 \pm 0.5$ & $12.5 \pm 0.1$ & $1.99 \pm 0.08$ & 2.0 \\
\hline $\mathrm{Sr}$ & $\leq 3$ & $0.138 \pm 0.003$ & $\leq 2$ & $\leq 0.8$ \\
\hline Mo & $3.02 \pm 0.30$ & $3.5 \pm 0.5$ & $\leq 0.4$ & $\leq 0.4$ \\
\hline $\mathrm{Ag}$ & $0.046 \pm 0.005$ & $0.04 \pm 0.01$ & $0.181 \pm 0.007$ & 0.181 \\
\hline $\mathrm{Cd}$ & $\leq 1$ & $0.44 \pm 0.06$ & $8.17 \pm 0.06$ & 8.51 \\
\hline $\mathrm{Sb}$ & $\leq 0.01$ & $(0.003)$ & $\leq 0.01$ & $\leq 0.08$ \\
\hline I & $\leq 2$ & NC & $\leq 1$ & $\leq 1$ \\
\hline $\mathrm{Cs}$ & $0.0123 \pm 0.0039$ & $\mathrm{NC}$ & $0.0069 \pm 0.0006$ & 0.006 \\
\hline
\end{tabular}

\begin{tabular}{llclc}
\hline \multirow{2}{*}{ ELEMENT } & \multicolumn{2}{l}{ NIST SRM } & 2710 Montana Soil & \multicolumn{2}{l}{ SRM 1571 Orchard Leaves } \\
& AVERAGE & CERTIFIED & AVERAGE & CERTIFIED \\
& & & \\
\hline
\end{tabular}

$\begin{array}{lllll}\mathrm{Hg} & 32.6 \pm 0.9 & 32.6 \pm 1.8 & 0.154 \pm 0.021 & 0.155 \pm 0.015\end{array}$

"Values in parentheses are for information only and are not certified values.

'NA = not analyzed

NC $=$ not certified 


